\title{
Refractive errors: occurrence, aspecific health complaints \& functional problems
}

Citation for published version (APA):

Hendricks, T. J. W. (2008). Refractive errors: occurrence, aspecific health complaints \& functional problems. [Doctoral Thesis, Maastricht University]. Universiteit Maastricht.

https://doi.org/10.26481/dis.20080229th

Document status and date:

Published: 01/01/2008

DOI:

$10.26481 /$ dis.20080229th

Document Version:

Publisher's PDF, also known as Version of record

\section{Please check the document version of this publication:}

- A submitted manuscript is the version of the article upon submission and before peer-review. There can be important differences between the submitted version and the official published version of record.

People interested in the research are advised to contact the author for the final version of the publication, or visit the DOI to the publisher's website.

- The final author version and the galley proof are versions of the publication after peer review.

- The final published version features the final layout of the paper including the volume, issue and page numbers.

Link to publication

\footnotetext{
General rights rights.

- You may freely distribute the URL identifying the publication in the public portal. please follow below link for the End User Agreement:

www.umlib.nl/taverne-license

Take down policy

If you believe that this document breaches copyright please contact us at:

repository@maastrichtuniversity.nl

providing details and we will investigate your claim.
}

Copyright and moral rights for the publications made accessible in the public portal are retained by the authors and/or other copyright owners and it is a condition of accessing publications that users recognise and abide by the legal requirements associated with these

- Users may download and print one copy of any publication from the public portal for the purpose of private study or research.

- You may not further distribute the material or use it for any profit-making activity or commercial gain

If the publication is distributed under the terms of Article $25 \mathrm{fa}$ of the Dutch Copyright Act, indicated by the "Taverne" license above, 
Refractive errors: occurrence, aspecific health complaints \& functional problems

Theo J.W. Hendricks 
(C) Theo J.W. Hendricks, Maastricht 2008

Cover illustration and design: Christel van der Loo Layout: Christel van der Loo

The studies in this thesis have been supported by Optitrade Retailgroep 
Refractive errors: occurrence, aspecific health complaints \& functional problems

\section{PROEFSCHRIFT}

ter verkrijging van de graad van doctor aan de Universiteit Maastricht, op gezag van Rector Magnificus, Prof. mr. G.P.M.F. Mols, volgens het besluit van het College van Decanen,

in het openbaar te verdedigen op vrijdag 29 februari 2008 om 16.00 uur

door

Theo J.W. Hendricks 


\section{Promotores}

Prof. dr. J.A. Knottnerus

Prof. dr. F. Hendrikse

Co-promotores

Dr. J. de Brabander

Dr. F.G. van der Horst

\section{Beoordelingscommissie}

Prof. dr. J.F.M. Metsemakers (voorzitter)

Dr. F.J.M. Feron (GGD Zuid Limburg, azM/UM)

Prof. dr. F.J.N. Nijhuis

Prof. dr. G.H.M.B. van Rens (Vrije Universiteit Amsterdam)

Dr. C.A.B. Webers 


\section{Contents}

$\begin{array}{lll}\text { Chapter } 1 & \text { General introduction and research questions } & 7\end{array}$

1.1 General introduction 9

1.2 Aims of the studies, research questions, and 13 outline of this thesis

Chapter 2 The relation between refractive error and non-visual complaints and/or functional problems: fact or fiction? A literature search

Chapter 3 Prevalence of refractive errors among Dutch schoolchildren and hospital employees

Chapter 4 Relationship between refractive errors and headache complaints in schoolchildren

Chapter 5 Uncorrected refractive errors in schoolchildren are a risk factor for lower school achievement

Chapter 6 Uncorrected spherical errors are a risk factor for health problems

Chapter 7 Does non-optimal correction of spherical refractive errors contribute to health complaints and sickness absence?

Chapter 8 Using plus-lenses next to visual acuity measurement as a low-tech measurement method to improve the detection of refractive errors in ambulatory settings

$\begin{array}{lll}\text { Chapter } 9 & \text { General discussion and conclusions } & 111\end{array}$

$\begin{array}{lll}9.1 & \text { Most important findings } & 113 \\ 9.2 & \text { Methodological considerations and study implications } & 114 \\ 9.3 & \text { Conclusions and recommendations for practice and } & 119\end{array}$

$\begin{array}{lr}\text { Summary } & 123\end{array}$

$\begin{array}{lr}\text { Glossary of used terms and abbreviations } & 129\end{array}$ 


\section{Chapter 1}

General introduction \& research questions

1.1 General introduction

1.2 Airns of the studies, research questions, and outline of this thesis 


\subsection{General introduction}

Information via the visual pathway has been recognised as of major importance for the development, growth, functioning and survival of many species on earth. Also in humans vision is a major sense, and a huge amount of the functional information is incorporated via the visual pathway. This has important implications for development (learning) in children and daily life functioning (such as job functioning) in adults. The human eye is the sensory instrument of the brain to make a visual connection with the outside world. Most important for the eye is that it is able to optically focus sharp images on the retina (refraction). Only then it is able to maximally transform optical energy (photons) via the retinal processes to higher order visual brain processes.

In ambulatory settings visual acuity (VA) is mostly measured using Snellen charts. If a patient is not able to read small letters, and his or her Snellen VA is for example less than 0.5 , practitioners normally will look for a cause of this diminished VA. If on the other hand a patient is able to read small letters, and the measured Snellen VA is for example 1.0 or more, many practitioners will not look further for ophthalmic causes for complaints presented by these patients.

Patients with refractive error (RE), especially in case of higher degrees of $R E$, often have diminished VA for distance. ${ }^{1,2}$ However, despite an emmetropic condition, VA is not necessarily optimal. Various other conditions like neural and retinal disorders, and opacity of cornea, lens and vitreous might influence VA. Moreover in patients small degrees of myopia and/or small to moderate degrees of hyperopia, despite their RE, Snellen VA might be 1.0 or more. VA and RE are different concepts, and as a consequence measurement of $V A$ seems to be a necessary but not sufficient method to detect or exclude RE.

The proportion of RE in the general population ranges from $13 \%$ to $80 \%$ in various studies. In different geographic areas and different age groups prevalence rates differ substantially. ${ }^{3-5}$ Different measurement methods used in the different studies do not substantially explain these differences in areas and age groups. The majority of RE can be corrected successfully using spectacles, contact lenses or refractive surgery. Nevertheless, successfully corrected RE does not automatically imply optimal visual functioning.

Although low degree RE is very often not accompanied with severe ocular disease, it may have consequences for the daily life of patients in terms of functional problems, and quality of life. Until now the focus of research regarding RE has not been on these possible consequences. ${ }^{6,7,24-26}$

These considerations brought us to explore the possible relation between $R E$, aspecific health complaints and functional problems. Moreover we investigated whether the use of plus-lenses next to simple VA measurement as a low-tech measurement method might be a feasible method to improve the detection of RE in ambulatory settings. 
This general introduction provides a general background on RE, aspecific health complaints and functional problems. Subsequently, the aim of the study, research questions, and outline of this thesis are presented.

\section{Refractive error}

If the focal power of the optical parts of the unaccommodated eye matches with the length of the eyeball, parallel rays of light entering the eye from a distant object focus into a sharp image upon the fovea. This condition is called emmetropia. In optical terms the far point of the emmetropic eye is situated in infinity. ${ }^{8}$

Despite an emmetropic condition, VA is not necessarily optimal. Various conditions like neural and retinal disorders, and opacity of cornea, lens and vitreous might influence VA.

To see sharp at closer distances (near point) than infinity the emmetropic eye must add "plus power" to its optical system. This process of accommodation is induced by stimulating the ciliary body causing relaxation of the zonular vessels enabling the lens to become more convex.

The accommodative power of the eye is very high at young age and decreases gradually with age. From the age of forty onwards the accommodative system is not able to provide comfortable reading at near distances anymore. In optical terms the near point is at longer distance than practically required. This is called presbyopia. A plus reading addition is then required for satisfactory seeing at near distances.

Variations from the emmetropic state are collectively referred to as ametropia or as RE. Emmetropia is best thought of as an ideal rather than a normal condition since almost all adults have some degree of RE. RE may be defined as a state in which the optical system of the non-accommodating eye fails to bring parallel rays of light to focus on the fovea. Differences between right and left eye ametropia is called anisometropia.

Although most researchers agree that people's refractive status is in large part genetically determined, a growing body of evidence shows that visual experiences early in life may affect ocular growth and possibly refractive status.

The principal forms of RE are myopia (nearsightedness) and hyperopia (farsightedness). Astigmatism is described as a sub-form of RE.

In myopia parallel rays of light focus in front of the fovea, causing blurred distance vision at all ages. The prevalence of myopia is increasing and it is a leading cause of loss of vision throughout the world. ${ }^{1,8-15}$

Depending on the amount of myopia the far point of the eye is situated somewhere between infinity and the eye itself. Therefore there is always a near distance at which a person with myopia can see sharp.

The eye itself is not able to correct for myopia. Some squeezing of eyelids usually helps a person with myopia to see better due to so called stenopeic effect. Correction of myopia can be done by spectacles, contact lenses, or refractive surgery. 
Hyperopia is the condition in which parallel rays of light after entering the unaccommodated eye focus behind the retina, causing blurred vision. Contrary to the myopic eye, the hyperopic eye is able to correct itself to a certain amount by using accommodation. Mild to moderate hyperopia can be overcome by accommodation in youth and early adulthood, with the result that low degrees of hyperopia are often not noticed until the onset of presbyopia in mid-adulthood.

Hyperopia is a common refractive disorder that has been overshadowed by myopia in the public perception, vision research and the scientific literature. ${ }^{6.7}$ Although uncorrected myopia has a greater adverse effect on visual acuity than uncorrected hyperopia, the close association between hyperopia, amblyopia, and strabismus, especially in children, makes hyperopia a greater risk factor for more permanent vision loss than myopia.

Astigmatism is a refractive anomaly due to different refraction of light in perpendicular meridians of the eye. This in most cases is caused by different curvatures of the outer surface of the cornea. Regular astigmatism can be corrected using cylindrical lenses. We have included astigmatism in this study because it may lead to distortion of the retinal image which cannot be compensated by regular accommodation. This would be particularly true for oblique astigmatism.

Aspecific health complaints

While the term "aspecific" refers to unclear causes of the complaints, well developed health complaints defined as "aspecific" by medical doctors are for patients often experienced as very clear. However, for patients the early recognition of their burden might be difficult because of the slowly progressive nature of their complaints which appears to lead to diminished awareness of signs of illness, sickness, and/or disease.

Aspecific health complaints are complex phenomena, influenced by many factors. The diagnostic process within this field is often difficult because many different factors, known or unknown, may contribute.

Many complaints presented in primary care practice are "aspecific". Headache for example is one of the 10 chief complaints of patients seen in primary care practices, and $47 \%$ of headaches have been reported to be of the tension-type. ${ }^{22}$

The substantial prevalence of these complaints encountered in primary care justify to more involve these complaints in ophthalmologic research.

Functional problems

Problems are called functional when they disturb daily life functioning. School achievement is an important indicator of functioning for children, and because school achievement scores may have influence on their future careers, we have focused on this indicator of functioning. Because for employees and employers sickness absence is easily measurable and has huge socio-economic consequences ${ }^{27,28}$, we focused on this indicator of functioning that can be used in a population of employees. $^{23}$ 
Relation between RE, aspecific health complaints, and functional problems In addition to the VA disturbances caused by RE, especially in children, many symptoms are suggested to be related to RE. Common symptoms and signs mentioned to be related to RE include blinking, frowning, rubbing the eyes, head tilting, closing one eye , clumsiness, photophobia, injection, and tearing. ${ }^{16-19}$ The effort of accommodation can, especially in adults result in "eyestrain" complaints. ${ }^{17-19}$ Headache, dizziness, and occasionally nausea have been suggested to have their origin in RE. ${ }^{17,18}$ In view of the close topographical and nervous connections between the eye and the brain it is not surprising that headaches have frequently been said to be associated with visual defects. ${ }^{20}$

Traditionally hyperopia or ciliary muscle strain is referred to as the cause of health complaints, since accommodation might arouse visual stress. ${ }^{16,19}$

Because in ophthalmology RE is not seen as an ophthalmic disease, the main aim of ophthalmologic research is the treatment of eye diseases and the improvement of visual acuity and other aspects of vision. For optometrists RE is the main subject of interest, however their interest is mainly focused at improving visual function rather than other aspects of daily complaints and/or health complaints. In primary health care aspecific health complaints are often subject of research, but measurement of $R E$ is not part of normal daily primary health care practice.

Therefore RE as a possible cause of aspecific health complaints seems to be a neglected domain in ophthalmologic and optometric research. ${ }^{21}$ Especially low degrees of $R E$ if present over longer periods of time might have impact on health complaints or functional problems. For this reasons we will pay attention to this phenomenon.

Aspecific health complaints might be related to functional problems such as lower school achievement or sickness absence. ${ }^{24-26}$

Assessment of aspecific complaints therefore might be of importance, not only in the process of identifying and diminishing patients complaints as such, but also in relation to functional problems.

If we are able to trace and favourably influence causes of aspecific health complaints it might help to reduce the impact on societal and socio-economic relevant outcome measures such as "school achievement" and "sickness absence" and, moreover, on daily functioning and quality of life.

Although RE in some cases can be detected easily by simple measurement of VA, in other cases it can be easily overlooked and therefore another measurement method should be used. Besides simple measurement of VA, measurement of VA with the use of plus and/or minus lenses RE can be used. Only in specialized settings the more advanced automatic refraction followed by a full subjective refraction is possible.

$R E$ can often be corrected easily, at relatively low costs. If the relation between $R E$ and the occurrence of aspecific health complaints and/or functional problems could be confirmed, for many persons these complaints and/or problems could be avoided or diminished. 


\subsection{Aim of the study, research questions and outline of the thesis}

Aim of the study

The aim of our research was to gain insight in the relation between RE, aspecific health complaints and functional problems.

The topics addressed in this thesis are: occurrence of RE, and the relation between $R E$, headache complaints, school achievement, and sickness absence. More Insight in these relations might contribute to answering the question whether reduction of aspecific health complaints and of functional problems can be achieved by RE measurement in ambulatory settings.

\section{Research questions}

The following research questions were addressed:

1 What is the prevalence of refractive errors in children and adults in the Netherlands?

2 Do children with and without refractive errors differ with regard to school achievement scores?

3 Are headache complaints more prevalent among children and adults with refractive errors?

4 Which components of refractive error among adults are most relevant in causing non-visual complaints and/or functional problems?

5 Is sickness absence related to refractive error?

6 What is the additional diagnostic value of using plus-lenses next to visual acuity measurement in order to detect refractive errors in ambulatory settings?

The research consisted of a literature analysis and surveys in primary school children (age $11-13$ years) and hospital employees (age 17-60 years).

Outline of the thesis

In chapter 2 we show the results of a literature search on the relation between refractive error and non-visual complaints and/or functional problems. The results of our study on prevalence of refractive error in school children and hospital employees are presented in chapter 3 .

The following four chapters deal with the relation between refractive error and nonvisual complaints and/or functional problems. The relationship between refractive errors and headache complaints in school children is addressed in chapter 4. In chapter 5 we have explored whether or not uncorrected refractive errors in schoolchildren is a risk factor for lower school achievement. Chapter 6 describes a study on the relation between spherical RE and aspecific health problems. Chapter 7 focuses on non-optimal correction of ametropia as a contributing factor to sickness absence.

Chapter 8 presents the results of a cross-sectional study, investigating the additional diagnostic value of using plus-lenses next to visual acuity measurement in order to detect refractive errors in ambulatory settings. 
The General discussion (chapter 9) summarises the main conclusions and discusses the points raised by our research.

At the end a summary of the thesis is presented. 


\section{REFERENCES}

1 World Health Organization. Elimination of avoidable disability due to refractive errors. (WHO/PBL/00.79). Geneva:WHO, 2000.

2 Ellwein LB. Case finding for refractive errors: assessment of refractive error and visual impairment in children. Community Eye Health 2002;15(44):60-61.

3 Rose K, Smith W, Morgan I, Mitchell P. The increasing prevalence of myopia: implication for Australia. Clin Exp Ophthalmol. 2001;29:116-120.

4 Seet B, Wong TY, Tan DT, Saw SM, Balakrishnam V, Lee LK. Myopia in Singapore: taking a public health approach. Br J Ophthalmol. 2001;85:521-526.

$5 \quad$ Fredrick DR. Myopia. BMJ 2002;324:1195-1199.

6 Grosvenor T. The neglected hyperope. Am J Optom physiol Opt 1971;48:376-82.

7 Rosner J. The still neglected hyperope. Optom Vis Sci 2004;81(4):223-224.

8 Fredrick DR. Myopia. BMJ 2002;324:1195-1199.

9 Ting PW, Lam CS, Edwards MH, Schmid KL. Prevalence of myopia in a group of Hong Kong microscopists. Optom Vis Sci. 2004 Feb;81(2):88-93.

10 Kempen JH, Mitchell $P$, Lee KE, Tielsch JM et al. The prevalence of refractive errors among adults in the United States, Western Europe, and Australia. Arch Opthalmol. 2004Apr;122(4):495-505.

11 Park DJ, Congdon NG. Evidence for an "epidemic" of myopia. Ann Acad Med Singapore. 2004 Jan;33(1):21-6.

12 Midelfart, A., Kinge B., Midelfart S.\& Lydersen S. Prevalence of refractive errors in young middle-aged adults in Norway. Acta Ophthalmo. Scand. 2002 Oct;80(5): 501505.

13 Junghans BM, Crewther SG. Prevalence of myopia among primary school children in eastern Sydney. Clin Exp Optom. 2003; 86(5):339-45 population-based prevalence surveys. Invest Ophthalmol Vis Sci. 2005Aug;46(8):2760-5.

14 Grosvenor T. Why is there an epidemic of myopia? Clin Exp Optom. 2003 Sep;86(5):273-5.

15 Rose K, Smith W, Morgan I, Mitchell P. The increasing prevalence of myopia: implication for Australia. Clin Exp Ophthalmol. 2001;29:116-120.

16 Vaughan D., Asbury T. (Textbook) General Ophthalmology $8^{\text {th }}$ edition, 1977 Lange Medical Publication:288-290.

17 Waters WE. Headache and the eye. The Lancet 1970 Aug; 2(7670):467-468.

18 Gordon DM. Some headaches in an ophthalmologist's office. Headache 1966 Oct (6):140-145.

19 Moore BD, Augsburger AR, Ciner EB, Cockrell DA, Fern KD. Optometric clinical practice guideline, care of the patient with hyperopia. American Optometric Association Consensus Panel on Care of the patient with hyperopia. American Optometric Association 1997.

20 Eckhardt LB, McLean JM, Goodell H. Experimental studies on headache: the genesis of pain from the eye. Proc Assoc Res Nerv Ment Dis 1943;209-227.

21 Goldschmidt E. The mystery of myopia. Acta Ophthalmol Scand. 2003 Oct;81(5):431-6.

22 Rasmussen BK, Jensen R, Schroll M. Epidemiology of headache in a general population: a prevalence study. J Clin Epidemiol 1991;44(11):1147-57.

23 Pärssinen TO. Relation between refraction, education, occupation, and age among 26and 46-year-old Finns. Am J Optom Physiol Opt 1987 Feb;64(2):136-143.

24 Rasmussen BK, Jensen RZ, Olesen J. Impact of headache on sickness absence and utilisation of medical services: a Danish population study. J Epidemiol Community Health 1992;46(4):443-6.

25 Rosner J. The relation between moderate hyperopia and academic achievement: how much plus is enough? J Am Optom Assoc 1997;68:648-50.

26 Pärssinen TO. Relation between Refraction, Education, Occupation, and Age among 26- and 46-Year-Old Finns. Am J Optom Physiol Opt 1987 Feb; 64(2):136-143. 
27 Headache Classification Committee of the International Headache Society.

Classification and diagnostic criteria for headache disorders, cranial neuralgias and facial pain. Cephalalgia. 1988;8(suppl 7):1-96.

28

Steiner TJ, Fontebasso M. Headache. BMJ 2002 Oct;325(7369):881-6. 


\section{Chapter 2}

The relation between refractive error and non-visual complaints and/or functional problems: fact or fiction? A literature search

Theo J.W. Hendricks ${ }^{1}$

John de Brabander

Frans $G$. van der Horst ${ }^{1,3}$

Marijke van den Berg

Fred Hendrikse?

J. André Knottnerus ${ }^{1.3}$

1 University of Madstricht, Depantment of Genelal Patice. We Netherlands

2 University of Maastricht/Acedemic Hospital Maastridn, Depaftnent of Ophthalmology. Eye Pesearch Institute Matastricht (EFiM), the Netherlands 


\title{
The relation between refractive error and non-visual health complaints and/or functional problems: fact or fiction? A literature search
}

\author{
ABSTRACT \\ Purpose \\ Refractive error (RE), especially myopia, is related to visual acuity (VA) and \\ ocular diseases. Moreover, it is suggested that RE, especially hyperopia, can \\ cause non-visual complaints and functional problems. A literature search was \\ performed on the possible influence of RE on the occurrence of non-visual \\ complaints and functional problems.
}

Methods The literature search included Medline searches (1966-2005) in which used keywords were: refractive error, hyperopia, myopia, complaints, symptoms, headache, fatigue, intelligence, reading, and dizziness. Moreover we searched in reference lists for other relevant articles. Articles published in English language (or with abstract in English) were included if the abstracts reported on possible relations between RE and medical complaints and/or functional problems.

Results

This literature search yielded fourty-one articles relating $R E$ and various nonvisual aspects. No case-control studies and randomized controlled trials with correction of RE as intervention, and only one cohort study were found. Studies discussing the relation between REs and headache do not show consistent relations between RE and headache complaints or aspecific health complaints. Little if any robust evidence supporting the theory that RE causes headache complaints was found.

Articles about relations between other non-visual aspects and RE, like vertigo and fatigue, were sparse.

A consistent pattern was found in which myopes score higher and hyperopes score lower on intelligence testing, compared to emmetropes. Reading ability and school achievement show the same pattern. Reading ability might according to the literature be an intervening factor in the relation between refractive error and intelligence.

Conclusions Research until now does not confirm RE as a cause of aspecific health complaints, but also does not exclude $R E$ as a relevant factor in relation with aspecific health complaints and/or functional problems. If a relation between the occurrence of RE and aspecific health complaints and/or functional problems could be confirmed in future research, for many persons these complaints and/or problems could be avoided or diminished.

Keywords Refractive error, myopia, hyperopia, non-visual health aspects, headache, dizziness, intelligence, reading ability. 


\section{INTPODUCTION}

The increasing prevalence of refractive error (RE) in children and young adults has been recognised as a worldwide problem by the World Health Organization $(\mathrm{WHO})^{1}$. $\mathrm{RE}$ is a common cause of visual impairment ${ }^{2-4}$, and (especially high) myopia is associated with ocular diseases such as glaucoma and retinal detachment ${ }^{5}$. Furthermore, it has been suggested in medical textbooks that RE (especially hyperopia) causes non-visual complaints such as headache and fatigue, and functional problems (such as lower school achievement, and lower reading and intelligence test scores). ${ }^{6,7} \mathrm{RE}$ is relatively simple to diagnose, and to resolve with spectacles, contact lenses or refractive surgery. If an association between RE and non-visual complaint and/or problems would exist, many patients could be relieved from (at least a part of) these burden by screening and correct treatment. This literature search reviews the evidence the suggested relation between RE and non-visual aspects is based on.

\section{METHODS}

A comprehensive MEDLINE search (Pubmed, 1966-2005) was undertaken using the keywords: refractive error, hyper(metr)opia, myopia, anisometropia, complaints, symptoms, headache, fatigue, intelligence, reading, sickness absence, and dizziness. Moreover we searched in reference lists for other (older) relevant articles. Studies published in the English language were considered. Studies were excluded if, despite the keywords, the study did not concern the relation between RE and nonvisual complaints and/or functional problems. Studies were categorized according to design: patient series, surveys, prospective cohorts, randomized clinical trials, systematic reviews.

\section{PESULTS}

To give a clear overview of the studies found, we grouped the non-visual complaints and functional problems in three categories: (1) headache, (2) other signs and symptoms, and (3) intelligence, reading ability, and/or school achievement. Studies relating RE and sickness absence were not found.

In the tables 1 to 3 we present chronologically the found studies relating RE and headache (table 1), RE and signs/symptoms other than headache (table 2), and RE and intelligence, reading ability and/or school achievement (table 3).

Refractiva error and headache (table 1)

In our literature search fourteen studies were found on this topic. Of two studies the design was not clear. ${ }^{8,9}$ The other study designs were patient series ${ }^{12,14-16,19,21}$, surveys $^{18,20,23}$, experiments ${ }^{13,17}$, and a review study ${ }^{22}$. In most of the studies the results of selective populations (instead of samples from the general population) are described, which might lead to sample bias in the described results. Prospective cohorts, and randomized clinical trials with correction of RE as intervention were not found. 


\begin{tabular}{|c|c|c|c|c|c|}
\hline Ref & Year & Objective & Setting & Design & Results \\
\hline 8 & 1904 & $\begin{array}{l}\text { To describe history } \\
\text { and etiology of } \\
\text { migraine. }\end{array}$ & (unclear) & (unclear) & $\begin{array}{l}\text { Eyestrain is cause of many health } \\
\text { complaints like headache. }\end{array}$ \\
\hline $\begin{array}{l}9 \\
\text { Snell }\end{array}$ & 1904 & $\begin{array}{l}\text { To describe causes of } \\
\text { headache and other } \\
\text { neuroses. }\end{array}$ & (unclear) & (unclear) & $\begin{array}{l}\text { Astigmatic correction of } 0.25 D \\
\text { could be sufficient to produce relief } \\
\text { of many health complaints. }\end{array}$ \\
\hline $\begin{array}{l}12 \\
\text { Turville }\end{array}$ & 1934 & $\begin{array}{l}\text { Looking for empirical } \\
\text { evidence relating RE } \\
\text { and headache }\end{array}$ & $\begin{array}{l}123 \text { migraine } \\
\text { cases with } \\
\text { (visual) aura } \\
\text { attending for } \\
\text { refraction }\end{array}$ & $\begin{array}{l}\text { patient } \\
\text { series }\end{array}$ & $\begin{array}{l}60 \% \text { required a hyperopic } \\
\text { prescription, } 20 \% \text { were myopic. } \\
\text { Half of the prescriptions given were } \\
\text { less than } 1 D .80 \% \text { of the subjects } \\
\text { experienced some relief from } \\
\text { headache following the prescription } \\
\text { of spectacles. }\end{array}$ \\
\hline $\begin{array}{l}13 \\
\text { Eckhardt }\end{array}$ & 1943 & $\begin{array}{l}\text { To investigate the } \\
\text { possible symptoms of } \\
\text { simulated RE. }\end{array}$ & (unclear) & experiment & $\begin{array}{l}\text { Simulated hypermetropia and } \\
\text { astigmatism leads to ocular } \\
\text { discomfort after a short period of } \\
\text { time. Simulated myopia does not } \\
\text { lead to ocular discomfort. }\end{array}$ \\
\hline $\begin{array}{l}14 \\
\text { Wilmut }\end{array}$ & 1956 & $\begin{array}{l}\text { To gain more insight in } \\
\text { the relation between } \\
\text { RE and migraine. }\end{array}$ & $\begin{array}{l}116 \text { patients } \\
\text { with migraine } \\
+ \text { unknown } \\
\text { number of } \\
\text { controls } \\
\end{array}$ & $\begin{array}{l}\text { patient } \\
\text { series }\end{array}$ & $\begin{array}{l}\text { There was no difference in the } \\
\text { distribution of } R E \text { between patients } \\
\text { with migraine and controls. }\end{array}$ \\
\hline $\begin{array}{l}15 \\
\text { Lanche }\end{array}$ & 1966 & $\begin{array}{l}\text { To evaluate the use } \\
\text { astigmatic } \\
\text { prescriptions in } \\
\text { patients with } \\
\text { headaches with ATR } \\
\text { astigmatism. }\end{array}$ & $\begin{array}{l}24 \text { patients } \\
\text { complaining } \\
\text { of headache, } \\
\text { with low } \\
\text { degrees of } \\
\text { ATR } \\
\text { astigmatism, } \\
\text { without } \\
\text { concurrent } \\
\text { spherical } \\
\text { ametropia }\end{array}$ & $\begin{array}{l}\text { patient } \\
\text { series }\end{array}$ & $\begin{array}{l}\text { Headache was resolved with } \\
\text { astigmatic prescription in all cases. }\end{array}$ \\
\hline $\begin{array}{l}16 \\
\text { Gordon }\end{array}$ & 1966 & $\begin{array}{l}\text { To gain more insight } \\
\text { into the type of patient } \\
\text { coming to an } \\
\text { ophthalmologist's } \\
\text { office because of } \\
\text { headache }\end{array}$ & $\begin{array}{l}100 \text { persons } \\
\text { with } \\
\text { headaches in } \\
\text { an } \\
\text { ophthalmolog } \\
\text { ist's office }\end{array}$ & $\begin{array}{l}\text { patient } \\
\text { series }\end{array}$ & $\begin{array}{l}28 \% \text { were found to have HARE and } \\
25 \% \text { were thought to have } \\
\text { headaches which were ocular in } \\
\text { origin but unrelated to RE. } 47 \% \text { of } \\
\text { headaches were thought to have } \\
\text { no relation to conditions within the } \\
\text { eye or the orbit. Males were found } \\
\text { more commonly to have an obvious } \\
\text { physical cause for their headaches } \\
\text { than females }\end{array}$ \\
\hline $\begin{array}{l}17 \\
\text { Vaithiling } \\
\text { ham \& } \\
\text { Khare }\end{array}$ & 1967 & $\begin{array}{l}\text { To evaluate whether } \\
\text { prescriptions of } \\
\text { spectacles for } \\
\text { uncorrected RE does } \\
\text { relieve headache } \\
\text { complaints. }\end{array}$ & $\begin{array}{l}301 \\
\text { headache } \\
\text { sufferers }\end{array}$ & experiment & $\begin{array}{l}90 \% \text { of the subjects experiences } \\
\text { relief from headaches with } \\
\text { spectacle wear, }\end{array}$ \\
\hline $\begin{array}{l}18 \\
\text { Waters }\end{array}$ & 1970 & $\begin{array}{l}\text { To determine how } \\
\text { often visual defects } \\
\text { (VA and ocular } \\
\text { imbalance) cause } \\
\text { headaches. }\end{array}$ & $\begin{array}{l}414 \\
\text { individuals } \\
\text { (aged } 25-74 \\
\text { years) out of } \\
\text { general } \\
\text { population of } \\
\text { South Wales }\end{array}$ & survey & $\begin{array}{l}\text { This survey suggests that in the } \\
\text { general population headaches are } \\
\text { seldom caused by visual defects } \\
\text { (VA). }\end{array}$ \\
\hline $\begin{array}{l}19 \\
\text { Cameron }\end{array}$ & 1976 & $\begin{array}{l}\text { To describe the } \\
\text { relation of headache to } \\
\text { the eyes. }\end{array}$ & $\begin{array}{l}50 \text { patients } \\
\text { referred to a } \\
\text { hospital eye } \\
\text { clinic with } \\
\text { headache }\end{array}$ & $\begin{array}{l}\text { patient } \\
\text { series }\end{array}$ & $\begin{array}{l}36 \% \text { were suffering from migraine, } \\
54 \% \text { from tension headache, } 4 \% \\
\text { found relief from the headaches by } \\
\text { wearing a hyperopic correction. }\end{array}$ \\
\hline
\end{tabular}




\begin{tabular}{|c|c|c|c|c|c|}
\hline $\begin{array}{l}20 \\
\text { Daum et } \\
\text { al. }\end{array}$ & 1988 & $\begin{array}{l}\text { To evaluate the } \\
\text { proportion of myopes, } \\
\text { emmetropes, and } \\
\text { hyperopes with } \\
\text { headache symptoms. }\end{array}$ & & survey & $\begin{array}{l}\text { Myopes and hypermetropes } \\
\text { reported more symptoms than } \\
\text { emmetropic subjects (curiously a } \\
\text { greater proportion of myopes than } \\
\text { hypermetropes were symptomatic). }\end{array}$ \\
\hline $\begin{array}{l}21 \\
\text { Gil- } \\
\text { Gouveia } \\
\text { \& } \\
\text { Pavo- } \\
\text { Martins }\end{array}$ & 1999 & $\begin{array}{l}\text { To evaluate the } \\
\text { association between } \\
\text { headache and RE. }\end{array}$ & $\begin{array}{l}47 \text { headache } \\
\text { patients with } \\
\text { uncorrected } \\
\text { RE attending } \\
\text { hospital }\end{array}$ & $\begin{array}{l}\text { patient } \\
\text { series }\end{array}$ & $\begin{array}{l}72 \% \text { reported reduced frequency of } \\
\text { their headaches } 10 \text { months after } \\
\text { spectacles were prescribed. }\end{array}$ \\
\hline 22 & 2001 & $\begin{array}{l}\text { To review available } \\
\text { empirical evidence on } \\
\text { the relation between } \\
\text { RE and headaches. }\end{array}$ & $=$ & review & $\begin{array}{l}\text { Despite the apparent belief of both } \\
\text { medical and optometric } \\
\text { professionals, that provision of an } \\
\text { appropriate correction may } \\
\text { alleviate various types of } \\
\text { headache, there is little evidence in } \\
\text { support of this position. } \\
\text { Uncorrected RE as a factor in the } \\
\text { generation of headache could } \\
\text { neither be supported nor rejected. }\end{array}$ \\
\hline $\begin{array}{l}23 \\
\text { Gil- } \\
\text { Gouveia } \\
\text { Martins }\end{array}$ & 2002 & $\begin{array}{l}\text { To compare overall } \\
\text { headache frequency } \\
\text { and HARE frequency } \\
\text { in healthy subjects } \\
\text { with uncorrected or } \\
\text { miscorrected RE and a } \\
\text { control group. }\end{array}$ & $\begin{array}{l}105 \\
\text { individuals } \\
\text { with } \\
\text { uncorrected } \\
\mathrm{RE} \text { and } 71 \\
\text { individuals } \\
\text { with properly } \\
\text { corrected or } \\
\text { without RE, } \\
\text { attending an } \\
\text { outpatient } \\
\text { occupational } \\
\text { clinic for } \\
\text { health } \\
\text { checkups } \\
\end{array}$ & survey & $\begin{array}{l}\text { A small proportion (6.6\%) of } \\
\text { individuals with RE do suffer from } \\
\text { HARE. HARE appears to be linked } \\
\text { with hyperopia. In people suffering } \\
\text { from chronic headache a } \\
\text { decreased frequency of headache } \\
\text { complaints was found after proper } \\
\text { correction of RE. }\end{array}$ \\
\hline
\end{tabular}

This topic has been dominated by clinical anecdote throughout the $20^{\text {th }}$ century. The issue has been clouded moreover, by the various methods headache was classified within the literature. Heterogeneous groups (often without control groups) have been investigated, with presumably different headache pathogenesis.

In the early part of the $20^{\text {th }}$ century, the issue of whether headache was caused by RE was a topic of lively debate in medical literature. Gould $(1904)^{8}$ pronounced his opinion that eyestrain produced many health complaints. This view was supported by Snell $(1904)^{9}$, who asserted moreover that an astigmatic correction of 0.250 could be sufficient to produce relief. Such views were so widely held that Baker $(1904)^{10}$ considered the issue closed.

Posey and Spiller (1906) ${ }^{11}$ commented that by the same logic as used by Baker it would be possible to prove that eyestrain might be responsible for any disease which happens to appear in a patient with little astigmatism. Bakers' data were generated in response to a retrospective questionnaire that was both too biased and too brief to be credible.

Turville $(1934)^{12}$ attempted to find empirical evidence, rather than clinical view, relating $\mathrm{RE}$ and headache. Because a control group and statistical tests were not conducted on the data, the provided evidence is not firm.

Eckhardt et al.(1943) ${ }^{13}$ found that subjects required to wear lenses simulating 5D of hypermetropia complained of ocular discomfort after a short period of time. 
Discomfort was further aggravated by near work. Similar symptoms were generated in simulated astigmatism but not in simulated myopia. Unfortunately the experimental method was not described, and no control condition was employed. Also it is not clear how many subjects were tested and for how long. Wilmut (1956) ${ }^{14}$ did not make explicit how patients were recruited; it seems that he used a consecutive series. Further the testing was undertaken by a number of different practitioners using different techniques.

Lanche (1966) ${ }^{15}$ described a consecutive series of 24 patients with low degrees of 'against-the-rule' astigmatism $(0.50 \mathrm{D}$ or $0.75 \mathrm{D})$ without concurrent spherical ametropia. These patients complained of headache. The headache was resolved by astigmatic prescriptions in all cases. However, it is unclear how, or even if, the patients were followed up to confirm this assertion. Lanche also omitted to provide control data for his series.

Among 100 patients with headaches or pain in the eye, referred to an ophthalmologist, Gordon $(1966)^{16}$ found that in 28 patients their headaches were accompanied by RE. These headaches were thought to usually appear frontal in location, and might often be accompanied by corrugation of the brows. It was reported that the need for a minor change in correction might cause more headache and symptoms of eyestrain than the need for a major correction. Eye straining is in his opinion a more common cause of headache than generally realized. These conclusions are based on clinical experience, but the strength of the evidence base is far from clear.

Waters $(1970)^{18}$ concluded that in the general population, headaches are seldom caused by decreased visual acuity (VA) or ocular imbalance. He investigated the relation between headache, VA and ocular imbalance in a study among people with different headaches and a control group without headache. In 24 chi-square analyses the only significant result found was that hyperphoria appeared to be more prevalent in patients suffering from migraine. Waters at no stage actually measured RE. Using VA as a substitute for RE, the used method is not adequate because in patients without RE their VA may be abnormal (for example macula degeneration, amblyopia, damage of optical cortex) and because low degrees of RE may still have good VA. Also, hyperopes with strong accommodative ability can have normal VA.

Gordon $(2001)^{22}$ reviewed the available research concerning the causation of headache by RE. This review showed that data and methods generally were not adequately documented as different definitions of headache and RE were used, prevalence of both RE and headaches is high, co-morbidity can not be excluded, and no prospective research was found. It was reported that uncorrected RE as a factor in the generation of headache could neither be supported nor rejected.

Gil-Gouveia (2002) ${ }^{23}$ concluded that Headache Associated with RE (HARE) in individuals with RE was rarely identified. It was associated with hyperopia and was unrelated to visual effort or the severity of visual error. In people suffering from chronic headache, a decreased frequency of headache complaints was found after proper correction of RE. Melis (2005) ${ }^{24}$ commented on the definition of HARE that its criterja are chosen too narrow, and therefore do not cover the full headache domain associated with refractive error. HARE would in that case be misdiagnosed as other types of headache, while the patient still could benefit from correcting RE. 
Considering the available literature it is clear that the role RE plays in the causation of headache is not as strong as medical textbooks suggest. In fact, research in this field neither can confirm nor reject the presumed relation between RE and headache. If $R E$ causes headache, the etiological mechanism is unclear. Ciliary muscle fatigue (in case of hyperopia) ${ }^{23}$, brow furrowing ${ }^{24}$, and contraction of the pericranial and neck muscles in an attempt to maintain a clear image ${ }^{24}$ have been suggested as etiological mechanisms. An interesting thought mentioned by Gordon ${ }^{16}$ is that a minor RE might more often cause headache complaints than a major RE. Gordon mentioned that for patients "unclear" minor RE might be more awkward than "clear" major RE.

It can be concluded that although there is a strong popular belief of a causative effect, there is no strong evidence that RE can be a cause of chronic headaches.

Refractive error and other symptoms (table 2)

Our literature search relating RE and other symptoms yielded four articles. One article reported on a study using an uncontrolled experiment as design ${ }^{25}$, and the other two studies ${ }^{26,28}$ discussed patient series. One article ${ }^{27}$ comprised a guidelines committee report. In these articles blurred vision, diplopia, asthenopia are mentioned (among other symptoms) as symptoms caused by RE.

Table 2 Studiespublications about the relation betwen RE and signs \& symptoms (headache exclucied)

\begin{tabular}{|c|c|c|c|c|c|}
\hline Ref & Yean & Objective & Setting & Design & Pesults \\
\hline $\begin{array}{l}25 \\
\text { Walton } \\
\text { et al. }\end{array}$ & 1978 & $\begin{array}{l}\text { To evaluate what } \\
\text { symptoms are } \\
\text { related to (induced) } \\
\text { hyperopia. }\end{array}$ & $\begin{array}{l}42 \text { optometry } \\
\text { students (age } \\
22-31 \text { years) }\end{array}$ & $\begin{array}{l}\text { Experiment } \\
\text { (un- } \\
\text { controlled) }\end{array}$ & $\begin{array}{l}\text { Blurred vision, distortion of vision, } \\
\text { exhaustion, diplopia and pulling } \\
\text { sensation in the eyes, nausea, the } \\
\text { desire to retreat from a (near-)task } \\
\text { are reported under induced } \\
\text { hyperopia. }\end{array}$ \\
\hline $\begin{array}{l}26 \\
\text { Daum }\end{array}$ & 1983 & $\begin{array}{l}\text { To examine the } \\
\text { nature of } \\
\text { accommodative } \\
\text { insufficiency. }\end{array}$ & $\begin{array}{l}96 \text { patients with } \\
\text { accommodative } \\
\text { insufficiency } \\
\text { (optometrist } \\
\text { population), } \\
\text { Ohioa } \\
\end{array}$ & $\begin{array}{l}\text { patient } \\
\text { series }\end{array}$ & $\begin{array}{l}\text { Blur, headaches and asthenopia } \\
\text { were most often reported as } \\
\text { symptoms. A variety of other } \\
\text { symptoms (diplopia, reading } \\
\text { problems, fatigue, photophobia) } \\
\text { were less frequently present. }\end{array}$ \\
\hline $\begin{array}{l}27 \\
\text { Moore et } \\
\text { al. }\end{array}$ & 1997 & $\begin{array}{l}\text { To provide a } \\
\text { guideline for the } \\
\text { care of the patient } \\
\text { with hyperopia }\end{array}$ & - & $\begin{array}{l}\text { Guidelines } \\
\text { committee } \\
\text { report }\end{array}$ & $\begin{array}{l}\text { Constant to intermittent blurred } \\
\text { vision, asthenopia, red and teary } \\
\text { eyes, frequent blinking, decreased } \\
\text { binocularity, difficulty reading, } \\
\text { amblyopia and strabismus are } \\
\text { symptoms may be experienced by } \\
\text { patients with hyperopia. }\end{array}$ \\
\hline $\begin{array}{l}28 \\
\text { Anoh- } \\
\text { Tanon et } \\
\text { al. }\end{array}$ & 2000 & $\begin{array}{l}\text { To evaluate the } \\
\text { relation between } \\
\text { dizziness and } \\
\text { ophthalmic } \\
\text { disorders in } \\
\text { children. }\end{array}$ & $\begin{array}{l}523 \text { children } \\
\text { (age } 3-13 \\
\text { years) with } \\
\text { vertigo, } \\
\text { dizziness, } \\
\text { and/or dis- } \\
\text { equilibrium, } \\
\text { otolaryngology } \\
\text { department }\end{array}$ & $\begin{array}{l}\text { patient } \\
\text { series }\end{array}$ & $\begin{array}{l}\text { Ocular disorders such as RE can } \\
\text { be responsible for vertigo, } \\
\text { instability, dizziness, and } \\
\text { equilibrium disorders in children. }\end{array}$ \\
\hline
\end{tabular}


Walton et al. (1978) 25 induced hyperopia in optometry students to evaluate the effects of short periods of induced hyperopia. Induced hyperopia of 1.00D, 1.50D and $2.00 \mathrm{D}$ produced an increase in symptoms, particularly a desire to retreat from a near task, nausea, and headaches. This study comprised a relatively small study population and no control group.

Daum $(1983)^{26}$ in examining the nature of accommodative insufficiency found that blurred vision, headaches and asthenopia were most often reported symptoms. More than half of the patients $(53 \%)$ reported total alleviation of their symptoms with plus lenses.

According to Moore et al (1997) ${ }^{27}$ many signs are related to hyperopia. Among these are red or tearing eyes, squinting and facial contortions while reading, ocular fatigue or asthenopia, frequent blinking, constant or intermittent blurred vision, focusing problems, and decreased binocularity and eye-hand coordination. Furthermore, difficulty with or aversion to reading are among the signs and symptoms of hyperopia. The presence and severity of these symptoms varies widely. Some young patients with hyperopia, including those with moderate and high hyperopia, may be relatively free of signs and symptoms

Anoh-Tanon $(2000)^{28}$ concluded that vertigo and dizziness in children can be caused by simple ocular disorders. In this study, 27 out of 523 children with vertigo and normal vestibular and neurological examinations presented ophthalmologic disorders. Out of these, 19 children did have refractive errors (hyperopia, myopia, and/or astigmatism). Patients symptoms were completely resolved by refractive treatment in two thirds of this group. In this small study group, a placebo-effect can not be excluded.

The available literature discussing the role RE plays in the causation of other complaints than headache is sparse. Found associations are based on patient series and clinical anecdote. Etiological evidence was not given. Although the findings are interesting, more prospective studies are needed to confirm a possible causal role of RE in these complaints. In these prospective studies complaints should be classified properly.

Refractive error and intelligence, reading ability and school achievement (table 3)

Twenty-four studies were found relating RE with intelligence, reading ability and/or school achievement. The study designs used in these studies were a case report ${ }^{29}$, surveys $^{30-33,37-43,45,46,48,50-54}$, and review studies ${ }^{35,40,41,44,47}$. 
Table 3 Studies about the relation between refractive error and intelligence. reading ability andior school achievement

\begin{tabular}{|c|c|c|c|c|c|}
\hline Ref & Year & Objective & Setting & Design & Results \\
\hline $\begin{array}{l}29 \\
\text { Pfingst }\end{array}$ & 1921 & $\begin{array}{l}\text { To describe the } \\
\text { association } \\
\text { between RE and } \\
\text { feeblemindedness }\end{array}$ & - & case report & $\begin{array}{l}\text { Feeble-mindedness is associated } \\
\text { with a considerable degree of } \\
\text { hypermetropia }\end{array}$ \\
\hline $\begin{array}{l}30 \\
\text { Goodsell }\end{array}$ & 1925 & $\begin{array}{l}\text { To investigate the } \\
\text { relation between } \\
\text { intelligence, mental } \\
\text { ability and perfect } \\
\text { eyesight }\end{array}$ & $\begin{array}{l}134 \text { high school } \\
\text { students in Los } \\
\text { Angeles }\end{array}$ & survey & $\begin{array}{l}\text { High intelligence and mental ability } \\
\text { are not dependent upon perfect } \\
\text { eyesight. }\end{array}$ \\
\hline $\begin{array}{l}31 \\
\text { Kurz }\end{array}$ & 1928 & $\begin{array}{l}\text { To describe the } \\
\text { proportion of } \\
\text { hypermetropia in } \\
\text { individuals of } \\
\text { subnormal } \\
\text { intelligence } \\
\text { compared to normal } \\
\text { individuals } \\
\end{array}$ & $\begin{array}{l}216 \text { feeble- } \\
\text { minded inmates } \\
\text { (aged } 4-40 \\
\text { years) in a } \\
\text { Swiss institution }\end{array}$ & survey & $\begin{array}{l}\text { More moderate and high degrees } \\
\text { of hypermetropia were found } \\
\text { among feeble-minded inmates, } \\
\text { compared to normal persons of } \\
\text { like ages. }\end{array}$ \\
\hline $\begin{array}{l}32 \\
\text { Schwartz }\end{array}$ & 1928 & $\begin{array}{l}\text { To Investigate the } \\
\text { relation between } \\
\text { RE and poor } \\
\text { reading }\end{array}$ & $\begin{array}{l}1100 \text { poor } \\
\text { reading school } \\
\text { children }\end{array}$ & survey & $\begin{array}{l}\text { Poor readers were primarily } \\
\text { hypermetropes ( } 58 \% \\
\text { hypermetropes and } 3.5 \% \\
\text { myopes). }\end{array}$ \\
\hline $\begin{array}{l}\text { 33 } \\
\text { Stocker }\end{array}$ & 1934 & $\begin{array}{l}\text { To describe the } \\
\text { proportion of } \\
\text { hypermetropia in } \\
\text { children of } \\
\text { subnormal } \\
\text { intelligence } \\
\text { compared to normal } \\
\text { school children } \\
\end{array}$ & $\begin{array}{l}124 \\
\text { institutionalized } \\
\text { children of } \\
\text { subnormal } \\
\text { intelligence }\end{array}$ & survey & $\begin{array}{l}\text { More hypermetropia was found in } \\
\text { children of subnormal intelligence } \\
\text { compared to normal school } \\
\text { children }\end{array}$ \\
\hline $\begin{array}{l}35 \\
\text { Von } \\
\text { Moers- } \\
\text { Messmer }\end{array}$ & 1940 & $\begin{array}{l}\text { Reviewing theories } \\
\text { of the cause of } \\
\text { myopia }\end{array}$ & - & review & $\begin{array}{l}\text { Myopia and high intelligence are } \\
\text { associated. }\end{array}$ \\
\hline $\begin{array}{l}37 \\
\text { Kirschen }\end{array}$ & 1954 & $\begin{array}{l}\text { To study the visual } \\
\text { performance of } \\
\text { mentally retarded } \\
\text { children }\end{array}$ & $\begin{array}{l}\text { Mentally } \\
\text { retarded } \\
\text { children in the } \\
\text { Modesto } \\
\text { (California) } \\
\text { State Hospital }\end{array}$ & survey & $\begin{array}{l}\text { A considerably greater frequency } \\
\text { of hypermetropia was found in } \\
\text { mentally retarded children, than in } \\
\text { a comparable normal population }\end{array}$ \\
\hline $\begin{array}{l}38 \\
\text { Young }\end{array}$ & 1955 & $\begin{array}{l}\text { To study the } \\
\text { relationship } \\
\text { between static } \\
\text { refraction and } \\
\text { intelligence } \\
\end{array}$ & $\begin{array}{l}\text { Employees } \\
\text { divided into } \\
\text { seven } \\
\text { occupational } \\
\text { groups } \\
\end{array}$ & survey & $\begin{array}{l}\text { There is no causal relationship } \\
\text { between } I Q \text { and } R E \text {. }\end{array}$ \\
\hline $\begin{array}{l}39 \\
\text { Kelly }\end{array}$ & 1957 & $\begin{array}{l}\text { To investigate the } \\
\text { relation between } \\
R E \text { and reading } \\
\text { ability }\end{array}$ & $\begin{array}{l}\text { General school } \\
\text { population, } 336 \\
\text { students }\end{array}$ & survey & $\begin{array}{l}\text { Myopes were better readers than } \\
\text { non-myopes and the better } \\
\text { readers tended to be myopic. }\end{array}$ \\
\hline $\begin{array}{l}40 \\
\text { Nadell \& } \\
\text { Hirsch }\end{array}$ & 1958 & $\begin{array}{l}\text { To compare } \\
\text { intelligence test } \\
\text { scores between } \\
\text { myopes and } \\
\text { hyperopes }\end{array}$ & - & review & $\begin{array}{l}\text { The literature suggest that a } \\
\text { correlation may be found between } \\
\text { refraction and intelligence where a } \\
\text { visual problem exists, but this may } \\
\text { very well be a correlation between } \\
\text { refractive state and the } \mathrm{IQ} \text { test } \\
\text { score, rather than the underlying } \\
\text { ability which the intelligence test } \\
\text { purports to measure. }\end{array}$ \\
\hline
\end{tabular}




\begin{tabular}{|c|c|c|c|c|c|}
\hline $\begin{array}{l}40 \\
\text { (cont.) }\end{array}$ & & & $\begin{array}{l}414 \text { students } \\
\text { (aged 13.5-17.9 } \\
\text { years) }\end{array}$ & survey & $\begin{array}{l}\text { Higher scores, although not } \\
\text { significantly different ( } p=0.10) \text {, on } \\
\text { intelligence tests in myopes } \\
\text { compared to hyperopes. The } \\
\text { relationship between refractive } \\
\text { state and intelligence is a } \\
\text { negligible one. }\end{array}$ \\
\hline \multirow[t]{2}{*}{$\begin{array}{l}41 \\
\text { Hirsch }\end{array}$} & \multirow[t]{2}{*}{1959} & \multirow[t]{2}{*}{$\begin{array}{l}\text { To compare } \\
\text { (different) } \\
\text { intelligence tests } \\
\text { scores between } \\
\text { myopes and } \\
\text { hyperopes }\end{array}$} & - & review & $\begin{array}{l}\text { 1. There seems to be a good } \\
\text { relationship between high } \\
\text { hypermetropia and low } \\
\text { intelligence. } \\
\text { 2. No evidence has been } \\
\text { encountered for association } \\
\text { between moderate } \\
\text { hypermetropia and reduction in } \\
\text { intelligence, but such claims } \\
\text { have been made. } \\
\text { 3. The presence of large numbers } \\
\text { of myopes in "intellectual" } \\
\text { occupations has been used as } \\
\text { evidence of the association of } \\
\text { myopia with intelligence. } \\
\text { 4. The myopic eye has been } \\
\text { considered as particularly } \\
\text { adapted to civilized life. }\end{array}$ \\
\hline & & & $\begin{array}{l}554 \text { secondary } \\
\text { school children } \\
\text { (aged 6-17 } \\
\text { years), Ohio }\end{array}$ & survey & $\begin{array}{l}\text { Myopes scored slightly higher on } \\
\text { intelligence tests than hyperopes. } \\
\text { The association between } \\
\text { moderate RE and moderate } \\
\text { intelligence test performance was } \\
\text { slight. }\end{array}$ \\
\hline $\begin{array}{l}42 \\
\text { Young }\end{array}$ & 1963 & $\begin{array}{l}\text { To investigate the } \\
\text { relationship } \\
\text { between reading } \\
\text { ability, intelligence } \\
\text { test scores and RE } \\
\text { as well as the } \\
\text { relationship } \\
\text { between refractive } \\
\text { error and } \\
\text { intelligence test } \\
\text { scores }\end{array}$ & 251 children & survey & $\begin{array}{l}\text { Myopes were significantly better } \\
\text { readers than non-myopes. Results } \\
\text { support the hypothesis that the } \\
\text { better performance of myopes on } \\
\text { intelligence tests which use fine } \\
\text { visual detail tasks is due to better } \\
\text { visual adjustment to this type of } \\
\text { task rather than to higher } \\
\text { intellectual ability, because } \\
\text { myopes were better readers than } \\
\text { hypermetropes and emmetropes. }\end{array}$ \\
\hline $\begin{array}{l}43 \\
\text { Grosven } \\
\text { or }\end{array}$ & 1970 & $\begin{array}{l}\text { To determine the } \\
\text { relation between } \\
\text { RE and intelligence } \\
\text { test scores with } \\
\text { reading ability held } \\
\text { constant. }\end{array}$ & $\begin{array}{l}290 \text { Caucasian } \\
\text { children (aged } \\
11-13 \text { years) in } \\
\text { New Zealand }\end{array}$ & survey & $\begin{array}{l}\text { Myopes performed better on } \\
\text { intelligence tests compared to } \\
\text { hypermetropes, especially on } \\
\text { language-tests. Significantly more } \\
\text { myopes were found in academic } \\
\text { classes than in regular classes. }\end{array}$ \\
\hline $\begin{array}{l}44 \\
\text { Grosver } \\
\text { nor }\end{array}$ & 1971 & $\begin{array}{l}\text { To put more } \\
\text { attention to the } \\
\text { problems that } \\
\text { hyperopes may } \\
\text { have. }\end{array}$ & - & review & $\begin{array}{l}\text { A growing body of literature } \\
\text { dealing with the relationship } \\
\text { between RE to intelligence test } \\
\text { scores, reading ability and school } \\
\text { achievement tends to show that } \\
\text { hyperopes may have problems. }\end{array}$ \\
\hline $\begin{array}{l}45 \\
\text { Gawron }\end{array}$ & 1981 & $\begin{array}{l}\text { To investigate } \\
\text { differences among } \\
\text { myopes, } \\
\text { emmetropes, and } \\
\text { hypermetropes } \\
\text { centered on physical } \\
\text { characteristics, } \\
\text { scholastic } \\
\text { achievement, and } \\
\text { personality traits, } \\
\end{array}$ & \begin{tabular}{|l|}
152 military \\
recruits (age $17-$ \\
28 years). \\
lilinois.
\end{tabular} & survey & $\begin{array}{l}\text { The RE groups differed in amount } \\
\text { of education. Myopes completed } \\
\text { more grades than emmetropes. }\end{array}$ \\
\hline $\begin{array}{l}46 \\
\text { Stewart- } \\
\text { Brown et } \\
\text { al. }\end{array}$ & 1985 & $\begin{array}{l}\text { To search for } \\
\text { evidence of } \\
\text { potential ill-effects } \\
\text { resulting from visual } \\
\text { defects among 10- }\end{array}$ & $\begin{array}{l}\text { 10-year-old } \\
\text { children with } \\
\text { visual defects, } \\
\text { United Kingdom }\end{array}$ & survey & $\begin{array}{l}\text { A small difference in intelligence } \\
\text { test scores was found in children } \\
\text { (aged } 10 \text { years), with children with } \\
\text { lower VA at far distance } \\
\text { (categorised as myopes) scoring }\end{array}$ \\
\hline
\end{tabular}




\begin{tabular}{|c|c|c|c|c|c|}
\hline & & year-old children. & & & $\begin{array}{l}\text { higher than children with lower VA } \\
\text { at near-distance (categorised as } \\
\text { hyperopes). }\end{array}$ \\
\hline $\begin{array}{l}47 \\
\text { Grisham } \\
\& \\
\text { Simons }\end{array}$ & 1986 & $\begin{array}{l}\text { To study the } \\
\text { relationships } \\
\text { between visual } \\
\text { functions (RE } \\
\text { included) and the } \\
\text { reading process }\end{array}$ & - & review & $\begin{array}{l}\text { 1. Distance VA is not related to } \\
\text { reading performance, except } \\
\text { possibly in the early grades. } \\
\text { 2. There is some evidence } \\
\text { supporting a relationship between } \\
\text { poor reading and reduced near } \\
\text { visual acuity, particularly binocular } \\
\text { acuity. } \\
\text { 3. Myopia generally does not } \\
\text { impair reading progress and } \\
\text { possibly might facilitate it. } \\
\text { 4. Hyperopia is associated with } \\
\text { poor reading performance and } \\
\text { prescribing hyperopic glasses } \\
\text { appears to improve reading skill. } \\
5 \text {. There is little evidence relating } \\
\text { astigmatism to reading, but studies } \\
\text { have not been adequately } \\
\text { designed to answer this question. } \\
6 \text {. Anisometropia appears to be } \\
\text { related to poor reading, and } \\
\text { correcting it with glasses appears } \\
\text { to result in improved reading } \\
\text { performance. } \\
\text { 7. RE is related, however weak, to } \\
\text { IQs within the normal range. } \\
8 . \text { Much work remains to be done } \\
\text { to confirm, revise and extend } \\
\text { these findings. }\end{array}$ \\
\hline $\begin{array}{l}48 \\
\text { Pärssi- } \\
\text { nen }\end{array}$ & 1987 & $\begin{array}{l}\text { To clarify whether } \\
\text { myopia has } \\
\text { increased in Finland } \\
\text { during recent } \\
\text { decades, and what } \\
\text { kind of connections } \\
\text { myopia has with } \\
\text { gender, education } \\
\text { and occupation } \\
\end{array}$ & $\begin{array}{l}466 \text { Finnish } \\
\text { people (aged } 26 \\
\text { and } 46 \text { years) }\end{array}$ & survey & $\begin{array}{l}\text { The mean refraction of } 26 \text {-year- } \\
\text { olds was about } 10 \text { more myopic } \\
\text { than that of } 46 \text {-year-olds. } \\
\text { Significantly more cases of myopia } \\
\text { were found among higher } \\
\text { educated people than among less } \\
\text { educated people. }\end{array}$ \\
\hline $\begin{array}{l}49 \\
\text { Williams } \\
\text { et al. }\end{array}$ & 1988 & $\begin{array}{l}\text { To compare verbal- } \\
\text { and performance } \\
\text { intelligence test } \\
\text { scores between } \\
\text { emmetropes, } \\
\text { myopes and } \\
\text { hyperopes }\end{array}$ & $\begin{array}{l}537 \text { children } \\
\text { from a } \\
\text { population } \\
\text { sample were } \\
\text { investigated } \\
\text { twice (at age of } \\
7 \text { and } 11 \text { years) }\end{array}$ & $\begin{array}{l}\text { cohort } \\
\text { study }\end{array}$ & $\begin{array}{l}\text { Although not significant, at the age } \\
\text { of } 11 \text { years a trend was found } \\
\text { where, compared to emmetropes, } \\
\text { myopes scored higher and } \\
\text { hyperopes scored lower on both } \\
\text { verbal- and performance } \\
\text { intelligence tests. }\end{array}$ \\
\hline $\begin{array}{l}50 \\
\text { Teasdale } \\
\text { et al. }\end{array}$ & 1988 & $\begin{array}{l}\text { To compare } \\
\text { intelligence test } \\
\text { scores and } \\
\text { educational levels } \\
\text { of myopes and } \\
\text { non-myopes, and to } \\
\text { correlate the degree } \\
\text { of myopia to } \\
\text { intelligence }\end{array}$ & $\begin{array}{l}5943 \text { myopes } \\
\text { and } 9891 \text { non- } \\
\text { myopes in } 18 \\
\text { year old military } \\
\text { men, Denmark }\end{array}$ & survey & $\begin{array}{l}\text { Myopes had higher test scores } \\
\text { and higher educational levels than } \\
\text { non-myopes. } \\
\text { Increasing levels of intelligence } \\
\text { and education are associated with } \\
\text { increasing degrees of myopia only } \\
\text { up to about }-2.00 \mathrm{D} \text {. }\end{array}$ \\
\hline $\begin{array}{l}51 \\
\text { Rosner } \\
\& \\
\text { Rosner }\end{array}$ & 1997 & $\begin{array}{l}\text { To test whether } \\
\text { uncorrected } \\
\text { hyperopia in } \\
\text { children is linked } \\
\text { with academic } \\
\text { learning problems; } \\
\text { and to evaluate the } \\
\text { minimal amount of } \\
\text { uncorrected } \\
\text { hyperopia that } \\
\text { appears to impede } \\
\text { elementary school } \\
\text { performance }\end{array}$ & $\begin{array}{l}782 \text { elementary } \\
\text { school children } \\
\text { (aged } 6-10 \\
\text { years) }\end{array}$ & survey & $\begin{array}{l}\text { Lower school-achievement scores } \\
\text { were found in uncorrected } \\
\text { hyperopes (more than } 1.250 \text { ) } \\
\text { compared to myopes and } \\
\text { emmetropes. }\end{array}$ \\
\hline
\end{tabular}




\begin{tabular}{|c|c|c|c|c|c|}
\hline $\begin{array}{l}52 \\
\text { Mutti et } \\
\text { al. }\end{array}$ & 2002 & $\begin{array}{l}\text { To quantify the } \\
\text { degree of } \\
\text { association } \\
\text { between juvenile } \\
\text { myopia and } \\
\text { parental myopia, } \\
\text { near work, and } \\
\text { school achlevement }\end{array}$ & $\begin{array}{l}366 \text { school } \\
\text { children (aged } \\
13.7 \pm 0.5 \\
\text { years), United } \\
\text { States }\end{array}$ & survey & $\begin{array}{l}\text { Compared to emmetropes and } \\
\text { hypermetropes, myopes ( } \geq- \\
0.75 D) \text { scored significantly higher } \\
\text { on reading and language tests; the } \\
\text { lower scores of hyperopes } \\
(\geq+1.0 D \text { ) were not significantly } \\
\text { different. Mathematics } \\
\text { achievement test scores were not } \\
\text { different between any of the } \\
\text { refractive groups. }\end{array}$ \\
\hline $\begin{array}{l}53 \\
\text { Saw et } \\
\text { al. }\end{array}$ & 2004 & $\begin{array}{l}\text { To evaluate the } \\
\text { association } \\
\text { between } \\
\text { intelligence and } \\
\text { myopia in children }\end{array}$ & $\begin{array}{l}1204 \text { Chinese } \\
\text { school children } \\
\text { (aged 10- } 12 \\
\text { years) }\end{array}$ & survey & $\begin{array}{l}\text { Nonverbal IQ may be an } \\
\text { independent risk factor of myopia, } \\
\text { and this relationship may not be } \\
\text { explained by increased reading } \\
\text { among myopes. }\end{array}$ \\
\hline $\begin{array}{l}54 \\
\text { Williams } \\
\text { et al. }\end{array}$ & 2005 & $\begin{array}{l}\text { To report on the } \\
\text { relation between } \\
\text { hyperopia and } \\
\text { education test } \\
\text { results }\end{array}$ & $\begin{array}{l}1298 \text { primary } \\
\text { school children } \\
\text { (aged } 8 \text { years), } \\
\text { United Kingdom }\end{array}$ & survey & $\begin{array}{l}\text { Hyperopes }(>+1.25 D) \text { scored } \\
\text { lower on school tests than to } \\
\text { children with a less positive } \\
\text { refractive state, which might point } \\
\text { at a link between hyperopia and } \\
\text { intelligence. }\end{array}$ \\
\hline
\end{tabular}

A number of authors (Goodsell $(1925)^{30}$, Roberts (1937) ${ }^{34}$, Duke-Elder $(1941)^{36}$ ) have suggested that myopes tend to obtain higher scores on intelligence tests than hypermetropes do. $I Q$ would be an intervening variable explaining why myopes might tend to read better than hyperopes.

Although not statistically significant $(p=0.10)$, Nadell and Hirsch $(1958)^{40}$ also reported higher scores on intelligence tests in myopes compared to hyperopes. To the extent that reading ability is visually grounded, in their idea, $R E$ may be indirectly associated with intelligence. The relationship between refractive state and intelligence is negligible, and neither factor can be utilized as a cause to "explain" the other.

In summarizing the historical considerations, ${\underline{\text { Hirsch }(1959)^{41}}}^{41}$ reported that the evidence for a relationship between refractive state and intelligence arises from four different types of observation. High hypermetropia (microphthalmos) is frequently associated with feeble-mindedness; an arrested development of eye, brain and other structures is probably underlying the relationship. There is some evidence also for the association of moderate hypermetropia with feeble-mindedness. There seem to be no studies involving those with intelligence slightly above or below the average. Myopia is claimed to be associated with higher intelligence, the arguments stemming from occupational choice and from speculation on the common embryological origin of brain and eye (retina). Either of these arguments may or may not be valid, and both lack experimental substantiality. Only one study was encountered (by Hirsch) in which intelligence and refraction were actually measured on a random sample of the population. In earlier literature no firm proof was found on the relation between $R E$ and intelligence. It should be mentioned that a definition of intelligence is not usually given in the papers that Goodsell ${ }^{30}$ reviewed and the criterion for intelligence is frequently far from clear. In his survey in 554 school children (aged 6-17 years), myopes scored higher on intelligence tests than hyperopes. The found relationship was not very strong.

Young $(1963)^{42}$ also investigated the relationship between reading ability, intelligence test scores and RE as well as the relationship between refractive error and intelligence test scores. The results support the hypothesis that the better 
performance of myopes on intelligence tests which use fine visual detail tasks is due to better visual adjustment to this type of task rather than to higher intellectual ability. Grosvenor (1970) ${ }^{43}$ reported a consistent tendency of myopes to perform better on intelligence tests, especially on language tests. He also found a relationship between the occurrence of RE and school-type level, in which myopes tended to come mainly from higher levels, compared to hyperopes. He did not control for other factors like intelligence or social class. In 1971 Grosvenor $^{44}$ reviewed the literature dealing with the relationship between $R E$ to intelligence test scores, reading ability and school achievement. Literature tends to show that hyperopes score lower on intelligence tests, reading ability and school achievement tests, compared to emmetropes and myopes.

Gawron (1981) ${ }^{45}$ evaluated differences among myopes, emmetropes, and hyperopes regarding physical characteristics, scholastic achievement, and personality traits. No significant differences in physical characteristics (specifically height and weight) or personality scales were found. The groups did differ in amount of education. Myopes completed more grades than emmetropes. In this study the quantity rather than the quality of educational performance was compared among myopes, emmetropes, and hyperopes.

Stewart-Brown $(1985)^{46}$ reported an increased intelligence among children (aged 10 years) with myopia and slightly reduced intelligence among children with amblyopia. Those with other visual defects had normal intelligence scores. In this study children with lower VA at far distance were categorised as myopes, and children with lower VA at near distance were categorised as hyperopes. Sex and social class were considered as confounders. Children with bilateral lower VA at near distance showed to be underachieving in reading and not in mathematics. Once intelligence had been taken into account only children with hypermetropia were underachieving at reading. Those with severe myopia were reading better than expected. None of the children could be shown to be over- or underachieving at maths, any variation being due to intelligence. Comparison of the performances of children with minor visual defects which had and had not been prescribed spectacles did not suggest any disadvantage for those without spectacles, with the possible exception of children with mild hyperopia. It was concluded that the majority of visual defects do not affect children's learning.

Grisham and Simons (1986) ${ }^{47}$ reported a literature analysis on the relation between $\mathrm{RE}$ and the reading process. Despite many limitations of studies $(1932-1985)$ they reviewed, a pattern of relationships between $R E$ and reading performance emerges from the data. The literature indicates that distance VA is not a predictor of reading skill, with the possible exception of the first few grades. Near point VA, on the other hand, may be an index associated with superior reading performance. Little evidence was found to suggest that myopia is related to reading problems in school children, but there are several studies which suggest that myopes have an advantage reading compared to others. Hyperopia seems to be associated with poor reading performance and correcting it with glasses appears to improve reading skills. Small amounts of uncorrected hyperopia seem to contribute to reading deficiencies. Although anisometropia is not highly prevalent among young school children, poorer reading can result in those afflicted. Little evidence was found relating astigmatism and reading. RE seems to be not strongly related to $1 Q s$ within the normal range. In 
their opinion much work remains to be done to confirm, revise and extend these findings.

Pärssinen (1987) ${ }^{48}$ investigated in 466 Finnish people (aged 26 and 46 years) the relation between refraction, education and occupation. Sphere equivalent of refractive error was most negative in higher educated groups. Significantly more cases of myopia were found among higher educated people than among less educated people. The prevalence of myopia in men employed in accurate close work was higher in the different educational groups. The amount of astigmatism had no relation to age, sex, or education.

Williams (1988) ${ }^{49}$ reported results of a study, in which 537 children from a population sample were investigated at age of 7 and 11 years. Although not significant, at the age of 11 years a trend was found where, compared to emmetropes, myopes scored higher and hyperopes scored lower on both verbal- and performance intelligence tests. These differences between the groups at age 11 were not attributable simply to the differences existing at age 7. No significant differences in reading scores were found at either age. It is concluded that differences in abilities of myopic and other children at age 11 are not fully explained by differences in family background or in pre-existing abilities.

Teasdale $(1988)^{50}$ compared intelligence of 5943 myopes and 9891 non-myopes in 18 year old military recruits and concluded that myopes had higher intelligence test scores and higher educational levels than non-myopes. In their opinion it might be possible that intelligence and educational level cause low degrees of myopia whereas genetic factors might become decisive in determining whether myopia develops into higher degrees. Increasing levels of intelligence and education are associated with increasing degrees of myopia only up to about -2.0D.

In 782 children (aged 6 years to 10 years) Rosner (1997) ${ }^{51}$ found lower schoolachievement scores in uncorrected hyperopes compared to myopes and emmetropes. He recommended practitioners to consider the potential benefit of correcting children with refractive error $>1.25 \mathrm{D}$.

In research by Mutti (2002) ${ }^{52}$, heredity was the most important factor associated with myopia, with smaller independent contributions from near work (especially studying and reading for pleasure), higher school achievement, and less time in sports activity. Watching television and playing computer games were not associated with myopia. Compared to emmetropes, myopes scored significantly higher on reading and language test scores, while hyperopes did not.

Saw et al $(2004)^{53}$ pointed at the complexity of the relationships between $I Q$, reading and myopia that warrants additional studies to clarify any cause-effect relationship. According to a recent study by Williams et al. $(2005)^{54}$ children with RE $>+1.25 \mathrm{D}$ scored lower on school tests than children with a less positive refractive state, which might point at a link between hyperopia and intelligence.

Whether RE is related to intelligence has been a topic for many years. Remarkable in the literature is the consistent pattern of myopes scoring higher, and hyperopes scoring lower on intelligence test compared to emmetropes. ${ }^{11-16,18-22}$ Not all mentioned differences are significant. ${ }^{11,12,14,16,18,22}$ Therefore, if RE is a causal factor on intelligence level, it probably is not a very large contribution. 
The speculative hypotheses found in literature as explanations for higher intelligence of myopes, and the lower intelligence of hyperopes, are describing different mechanisms. Myopia can be seen as an overdevelopment of the eye just as hyperopia is an underdevelopment, and ocular and cerebral development are related. ${ }^{12}$ Intelligence test scores may be influenced by the amount of reading a child does. $^{12}$ The more intelligent child may read more, and thus become more myopic. ${ }^{12}$ In taking the test, a myope has an advantage upon the ability to perceive fine detail efficiently. ${ }^{11}$ A mutual influence on intelligence as well as on refractive state might be caused by both genetics and environment. ${ }^{21}$ The role these mechanisms play might be of more importance in low degrees of RE than in higher degrees. Genetic factors might become decisive in higher degrees of RE. ${ }^{19}$

Research dividing intelligence tests into verbal and performance sub-tests, show a trend in which myopes score higher and hyperopes score lower on verbal tests, compared to emmetropes. Differences in performance sub-tests do not show such a clear pattern. Therefore, the relation between RE and intelligence seems to be confounded by reading ability. ${ }^{21}$

Most studies found had a cross-sectional design. Higher education-level and higher occupation-level, are associated with myopia. Finding a proper method to measure intelligence in relation to RE seems to be difficult. Because intelligence tests more or less rely on reading ability, it is hardly possible to separate these two factors.

Moreover, comparing the results of various studies in the reviewed literature was not possible due to the used different intelligence.

\section{CONCLUSION}

In medical books with educational purposes, RE (especially hyperopia) is said to be related to non-visual aspects, such as headache and school achievement. Research articles do not show consistent relations between RE and headache complaints or aspecific health complaints. Little if any robust evidence was found supporting the theory that RE causes headache complaints.

Articles about relations between other non-visual aspects and $R E$, like vertigo and fatigue, were sparse.

A consistent pattern was found in literature in which myopes scored higher on intelligence tests, and hyperopes scored lower, compared to emmetropes. Reading ability might explain this relation.

To conclude, research until now does not confirm RE as a cause of aspecific health complaints but also does not exclude RE as a relevant factor in relation with aspecific health complaints and/or functional problems. If RE would play a role in these aspects, many people might benefit from correction of their RE. Further research in this field is indicated. 


\section{REFERENCES}

1 World Health Organization. Elimination of avoidable visual disability due to refractive errors. (WHO/PBL/00.79). Geneva: WHO, 2000.

2 Rose K, Smith W, Morgan I, Mitchell P. The increasing prevalence of myopia: implication for Australia. Clin Exp Ophthalmol. 2001;29:116-120.

3 Seet B, Wong TY, Tan DT, Saw SM, Balakrishnam V, Lee LK. Myopia in Singapore: taking a public health approach. $\mathrm{Br} J$ Ophthalmol. 2001;85:521-526.

4 Taylor HR, Keeffe JE, Vu HT, Wang JJ, Rochtchina E, Pezzullo ML, Mitchell P. Vision loss in Australia. Med J Aust. 2005 Jun;182(11):565-8.

5 Saw SM, Gazzard G, Shin-Yen EC, Chua WH; Myopia and associated pathological complications. Opthalmic Physiol. Opt. 2005 sep; (25):381-91.

6 Vaughan D., Asbury T.; (Textbook) General Ophthalmology $8^{\text {th }}$ edition, 1977 Lange Medical Publication, ISBN 0-87041-103-9.

7 Kanski JJ. Clinical ophthalmology. $5^{\text {th }}$ edition, 2003 Butterworth-Heinemann, Edinburgh, ISBN 0-7506-5542-9.

8 Gould GM. The history and etiology of migraine. JAMA. 1904;42:239-244.

9 Snell S. Eyestrain as a cause of headache and other neuroses. Simpkin, Marshall, Hamilton, Kent and Co. London. 1904:56.

10 Baker AR. A statistical inquiry as to the relief and cure of migraine by the correction of errors of refraction. Opthal. Record. 1904;16:1-6.

11 Posey WC, Spiller WG. The eye and nervous system: Their diagnostic relations. 1906. JB Lippincot Co, Philadelphia.

12 Turville AE. Refraction and migraine. Br J Physiol Opt. 1938;10:62-80.

13 Eckhardt LB, McLean JM, Goodell H. Experimental studies on headache: the genesis of pain from the eye. Proc Assoc Res Nerv Ment Dis. Williams and Wilkins, Baltimore. 1943:209-227.

14 Wilmut EB. Br J Physiol Opt 1956;13:93-97.

15 Lanche RK. Asthenopia caused by "against-the-rule" astigmatism. Headache 1966;6:146-150.

16 Gordon MD. Some headaches in an ophthalmologist's office. Headache 1966 Oct; 6(3): $141-146$.

17 Vaithilingham E, Khare BB. Ocular headache and the optometrist $J$ Am Opt Assoc 1967;38:477-479.

18 Waters WE. Headache and the eye. The Lancet 1970 Aug; 2(7670): 467-468

19 Cameron ME. Headaches in relation to eyes. Med J Aust 1976;1:292-294.

20 Daum KM, Good G, Tijerina L. Symptoms in video display terminal operators and the presence of small refractive errors. J Am Opt Assoc 1988;59:691-697.

21 Gil-Gouveia R, Pavo-martins I. Headache associated with refractive errors- a follow up study. Cephalalgia 1999;19:441-442.

22 Gordon GE, Chronicle EP, Rolan P. Why do we still not know whether refractive error causes headaches? Towards a framework for evidence based practice. Ophthalmic Physiol Opt 2001 Jan;21(1):45-50.

23 Gil-Gouveia R, Martins IP. Headaches Associated With Refractive Errors: Myth or Reality? Headache $2002 \mathrm{Apr}$; 42(4): 256-262.

24 Melis M. Headaches associated with refractive errors. Overestimated or overlooked? Headache 2003 Mar; 43(3):297-298.

25 Walton HN, Schubert DG, Clark D, Burke W. Effects of induced hyperopia. Am J Optom Physiol Opt 1978(July);55(7):451-455.

26 Daum KM. Accommodative insufficiency. Am J Optom Physiol Opt 1983;60(5);352-359.

27 Moore BD, Augsburger AR, Ciner EB, Cockrell DA, Fern KD. Optometric clinical practice guideline, care of the patient with hyperopia. American Optometric Association Consensus Panel on Care of the patient with hyperopia. American Optometric Association 1997.

28 Anoh-Tanon MJ, Bremond-Gignac D, Wiener-Vacher SR. Vertigo is an underestimated symptom of ocular disorders: dizzy children do not always need mri. Pediatric Neurology July 2000;23(1):49-53. 
Pfingst AO. Extreme hypermetropia. Am J Ophth 1921;4(6):436-437. Goodsell JG. An experimrntal study of ocular and intelligence status of high school students. Am J Physiol Optics1925;6(4):504-513.

Kurz H. The refraction in feeble-minded individuals. Albrecht von Graefe's Archiv für Ophthalmologie 1927;118:500. Abstract: AM.J.Ophth 1928;11:249.

Schwartz FO. Ocular factors in poor readers in the Saint Louis public schools. Am J Ophth 1928;23(5):535-538.

Stocker F. Über Beziehungen zwischen Refraktion und Gehirnentwicklung. Albrecht von Graefe's Archiv für Ophthalmologie 1934;133:131-137. Abstract: Am J Ophth 1935;13: 385.

Roberts JAF. Sex-linked microphthalmia sometimes associated with mental deficiency. British Med J 1937;2:1213-16.

Moers von-Messmer $H$. Thoughts of a myopic individual about the question of myopia Klinische Monatsblätter für Augenheilkunde 1940;105:584-593.

Duke-Elder WS. Textbook of Opthalmology, Vol 2, St Louis: Mosby, 1941:1274-75.

Kirschen M. A study of visual performance of mentally retarded children. Am J Optom Arch Am Acad Optom 1954;31(6): 282-288.

Young FA. Myopes versus nonmyopes - a comparison. Am J Optom and Arch Am Acad Optom 1955;32(4):180-191.

Kelly CR. Visual screening and child development. Raleigh, NC: Department of Psychology, North Carolina State College, 1957.

Nadell MC, Hirsch MJ. The relationship between intelligence and the refractive state in a selected high school sample. Am J Optom Arch Am Acad Optom 1958 Jun; 35(6): 321-326.

Hirsch MJ. The relationship between refractive state of the eye and intelligence test scores. Am J Optom Arch Am Acad Optom 1959 Jan; 36(1): 12-21.

Young FA. Reading, measures of intelligence and refractive errors. Am J Optom Arch Am Acad Optom 1963;40:257-264.

Grosvenor T. Refractive state, intelligence test scores, and academic ability. Am J Optom Arch Am Acad Optom 1970;47(5):257-264.

Grosvenor T. The neglected hyperope. Am J Optom Arch Am Acad Optom 1971 Dec:376-382.

Gawron VJ. Differences among myopes, emmetropes, and hyperopes. Am J Optom Physiol Opt 1981 Sep;58(9):753-760.

Stewart-Brown S, Haslum MN, Butler N. Educational attainment of 10-year-old children with treated and untreated visual defects. Dev Med Child Neurol 1985 Aug; 27(4): 504513.

Grisham JD, Simons HD. Refractive error and the reading process: A literature analysis. J Am Optom Assoc 1986 Jan; 57(1):44-55.

Pärssinen TO. Relation between Refraction, Education, Occupation, and Age among 26- and 46-Year-Old Finns. Am J Optom Physiol Opt 1987 Feb; 64(2): 136-143. Williams SM, Sanderson GF, Share DL, Silva PA. Refractive error, IQ and reading ability: a longitudinal study from age seven to 11. Dev Med Child Neurol 1988 Dec; 30(6): 735-742.

Teasdale TW, Fuchs $\mathrm{J}$, Goldschmidt E. Degree of myopia in relation to intelligence and educational level. Lancet 1988 Dec; 2(8624): 1351-1354.

Rosner J, Rosner J. The relationship between moderate hyperopia and academic achievement: how much plus is enough? J Am Optom Assoc 1997 Oct; 68(10): 648-650. Mutti DO, Mitchell GL, Moeschberger ML, Jones LA, Zadnik K. Parental Myopia, Near Work, School Achievement, and Children's Refractive Error. Invest Ophthalmol Vis Sci 2002 Dec; 43(12): 3633-3640.

Saw SM, Tan SB, Fung D, Chia KS, Koh D, Tan DT, Stone RA. IQ and the association with myopia in children. Invest Ophthalmol Vis Sci 2004 Sep;45(9):2943-8.

Williams WR, Latif AHA, Hannington L, Watkins DR. Hyperopia and educational attainment in a primary school cohort. Arch Dis Child 2005 Feb; 90(2): 150-153. 


\title{
Chapter 3
}

\section{Prevalence of refractive error among Dutch schoolchildren and hospital employees}

\author{
Theo J.W. Hendricks \\ John de Brabander? \\ Frans G. van der Horst ${ }^{13}$ \\ Marlou H.P. Vankan-Hendricks ${ }^{1}$ \\ Fred Hendrikse? \\ J. André Knotnerus ${ }^{1.3}$
}

Submitted for publication

1 University of Matetricht. Deparment of Cenerat Practice, the Netherlands

2 University of Matstricht: Academic Hospitat Matstricht. Departhent of

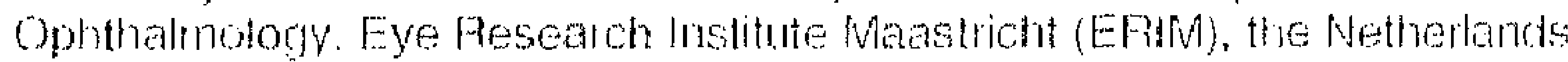

3 Care and Public Health Fesearch Institute (CAPIARI), University of Marstricht 


\section{Prevalence of refractive errors among Dutch schoolchildren and hospital employees}

\section{ABSTRACT}

Purpose Besides visual impairment, refractive errors are suggested to cause functional problems such as aspecific health complaints and lower school achievement. During the last few decades the prevalence of myopla has increased worldwide, especially in Asia. We investigated the prevalence of habitual refractive errors and anisometropia in a Dutch population of children and employees.

Methods In a cross-sectional study refractive errors of both eyes of 520 children (aged $11-13$ years) and 444 hospital employees (aged $17-60$ years) were measured using an autorefractometer (Topcon, RM-8000B). The measurements were performed without the use of a cycloplegium. The Pearson correlation coefficient $(r)$ was used to analyse correlations between right and left eyes. For testing differences between gender and age subgroups chi-square tests were used.

Results Among school children $28 \%$ of right eyes were myopic $>0.50 \mathrm{D}$ and $8 \%$ hyperopic $>0.50 \mathrm{D}$. For sphere equivalent power (SEP) Pearson's $r$ between right and left eyes was 0.93 . Mean cylinder component in right eyes was $0.26 \mathrm{D}$ [0.00D to $4.50 \mathrm{D}]$. Anisometropia $>1.00 \mathrm{D}$ was present in $4.6 \%$ of children; $22 \%$ of children were not optimally $(>0.50 \mathrm{D}$ ) corrected. Among hospital employees $30 \%$ of right eyes were myopic $>0.50 \mathrm{D}$ and $10 \%$ hyperopic $>0.50 \mathrm{D}$. For sphere equivalent Pearson's $r$ between right and left eyes was 0.53 . Mean cylinder component in right eyes was $0.35 \mathrm{D}$ [0.00D to $5.75 \mathrm{D}]$. Anisometropia $>1.00 \mathrm{D}$ was present in $25 \%$ of employees. In employees aged 40-60 years anisometropia was more frequently present than in employees aged $17-39$ years $(30 \%$ versus $18 \%, p=0.02$, Cramer's $V=0.15$ ).

Conclusions Refractive errors are common in schoolchildren aged 11-13 years and in hospital employees aged 17-60 years. Distributions of sphere and cylinder deviations are similar for Dutch school children and employees. Surprisingly, anisometropia proved to be more prevalent with age. In children many eyes are not optimally corrected. Increased attention should be paid to uncorrected and miscorrected refractive errors.

Keywords Refractive error, prevalence, astigmatism, myopia, hyperopia, Anisometropia. 


\section{INTRODUCTION}

Refractive error (RE) is a common cause of visual impairment. ${ }^{1,2}$ Refractive error (especially high myopia) is also associated with ocular diseases such as glaucoma and retinal detachment. ${ }^{2-4}$ Moreover, hyperopia might cause non-visual complaints, such as headache ${ }^{4}$ and fatigue ${ }^{6} ;$ which in turn might be related to functional problems such as lower school achievement. The majority of refractive errors can be corrected successfully using spectacles, contact lenses or refractive surgery. The availability of data on prevalence of ametropia is important to determine goals in the framework of health care policy.

Several studies have investigated the prevalence of RE in various populations. ${ }^{2,7-17}$ Substantial variation in prevalence of RE has been reported in relation to geographical area, ethnicity ${ }^{8.9}$, education level, age ${ }^{11,18}$, gender, and socio-economic status.

The prevalence of myopia varies by country and by ethnic group, reaching as high as $70-90 \%$ in some Asian populations, where myopia is a growing health care and socio-economic problem. ${ }^{2,19,20}$ In adults 40 years or older RE affect approximately 1 in 3 in the United States and Western Europe, and about 1 in 5 in Australia. Within an African population (Barbados) overall 9-year incidence was $12.0 \%$ for myopia and $29.5 \%$ for hyperopia. African persons aged 40 to 49 years (Barbados eye studies ${ }^{21}$ ) experienced increased prevalence of hyperopia, whereas persons $\geq 60$ years had increased prevalence of myopia. ${ }^{21}$ In Norway a survey in 2002 showed a slightly higher prevalence of myopia in the general population than previously estimated. ${ }^{11}$ Students performing extensive near work are reported to be at risk for developing myopia. ${ }^{21}$ The increasing prevalence of RE in children and young adults has been recognised as a worldwide problem by the $\mathrm{WHO}^{23,24}$

Besides simple spherical ametropia, astigmatism and anisometropia ${ }^{25}$ are important in relation to visual function. Older reports on anisometropia indicate no difference between age groups; recently a study reported anisometropia to be relatively stable between 20 and 40 years of age, but becoming more common with age, in myopes from the age of 40 onward and in hyperopes from the age of 70 onward. ${ }^{25,26}$

In the series of prevalence studies, adding data of different geographic areas is important in gradually gaining a complete documentation of the refractive error prevalence worldwide.

The aim of this study was to investigate the prevalence of habitual RE among schoolchildren (aged $11-13$ years) and healthy adult people (hospital employees aged 17-60 years) in the Netherlands. Particular attention is paid to the prevalence of myopia because of its association with visual impairment and ocular diseases, and to hyperopia because of its assumed association with functional problems. 


\section{METHODS}

Design and study population

The present study had a cross-sectional design. The subjects were recruited from a population of primary school children and a population of hospital employees in South Limburg, the Netherlands.

Children in their last primary school year (aged $11-13$ years) were asked to participate. The teachers distributed the study information to the children and their parents. Participation was voluntary. Children with eye pathology (except amblyopia) were excluded from this study. In order to maximize participation the measurements took place during school time hours.

Hospital employees working in the Atrium Medical Centre in Heerlen were asked to participate. In this general hospital in the Netherlands, department managers of a number of departments were asked to distribute study information among their employees. Both wards and support departments were included. In total 950 persons are employed at these departments. Employees working outside office hours and employees not on duty in the recruitment period $(\mathrm{N}=100)$ were not able to participate. Based on information of the personnel department, $6 \%(\mathrm{~N}=51)$ of employees were on sickness leave. The participating employees gave written informed consent. The Ethics Committee (Institutional Review Board) of the Atrium Medical Centre in Heerlen, the Netherlands, provided the ethical approval for this study.

\section{SURVEY MAEASURES}

Refractive error

In prevalence studies RE are measured using subjective or objective methods, with and/or without the use of cycloplegia. Because we wanted to evaluate the children and employees under conditions as close as possible to those under which they usually function (habitual RE), the use of a cycloplegium was not indicated. Information gained from cycloplegia (to detect latent hyperopia or pseudo-myopia) would have measured the absolute levels of their refraction deviations rather than their daily habitual RE which they are used to function with during their daily activities.

Habitual RE of both eyes was measured using an autorefractometer (Topcon RM$8000 \mathrm{~B}$ ). Spherical and astigmatic deviations were measured to the nearest $0.25 \mathrm{D}$. Astigmatic axes were measured to the nearest five degrees, negative cylinders being used for all measurements. Children and employees normally wearing an optical correction were measured with their glasses or contact lenses (habitual RE). The autorefractor as used in the data colfection has an automatic analysis system for image quality. If (e.g. by reflection from spectacle lenses) the image quality is too low, the instrument will display this measurement as an error. Each eye was measured three times, of which the average was taken. Right eyes were always measured before left eyes.

Values for refractive errors were converted into spherical equivalent power (SEP), calculated by adding half of the cylindrical value to the spherical value of the 
refractive error. SEP was divided into myopia $>0.50 \mathrm{D}$, emmetropia [-0.50D to $+0.50 \mathrm{D}]$, and hyperopia $>0.50 \mathrm{D}$. Anisometropia was divided in four categories [0.00D to $1.00 \mathrm{D}$, [1.01D to $2.00 \mathrm{D}$ ], [2.01D to $5.00 \mathrm{D}$ ] and $>5.00 \mathrm{D}$. Astigmatism (cylinder value) was divided in no astigmatism $[0.00 \mathrm{D}$ to $0.25 \mathrm{D}]$, and astigmatism $>0.25 \mathrm{D}$.

Data analysis

Data were analysed with the Statistical Package for Social Sciences (SPSS) version 10.0. Measurements from right and left eye were analysed separately. The Pearson correlation coefficient $(r)$ was used to analyse correlations between right and left eye measurements. Pearson Chi-Square test and Cramer's $V$ association measure were used to analyse differences in refractive error related to gender and age. In all analyses a significance level of 0.05 (two-tailed) was used.

\section{RESULTS}

\section{STUDY POPULATION}

\section{Schoolchildren}

Nineteen primary schools in the southern part of the Netherlands agreed to participate. Of the 588 children aged between 11 and 13 years in these classes, 520 children (88\%) took part in the study. Non-participation was due to absence/illness ( 37 children; $6 \%$ ); no permission of the parents ( 29 children; $5 \%$ ), and autorefractometer measurements not being obtained in $2(<1 \%)$ children. Of the 520 school children $52 \%$ were female; 74 children (14\%) were normally wearing an optical correction ( 32 boys and 42 girls).

\section{Hospital employees}

Among the 799 invited employees, the response was $56 \%(\mathrm{~N}=444)$. Of the respondents $273(61 \%)$ were female; $202(46 \%)$ employees were younger than 40 years. The average age was 40.4 years (SD 10.1, range 17 to 60 years). Of the 444 respondents $257(58 \%)$ employees were normally wearing an optical correction (109 men and 148 women).

Optometric examination/sphere equivalent power (SEP) of refractive error Table 1 shows the percentages of schoolchildren and hospital employees differentiated to myopia, emmetropia and hyperopia, for right and left eyes separately. Of the 520 right eyes of schoolchildren $27.9 \%$ was myopic $>0.50 \mathrm{D}, 64.4 \%$ emmetropic $[-0.50 \mathrm{D},+0.50 \mathrm{D}]$, and $7.7 \%$ hyperopic $>0.50 \mathrm{D}$; for the left eyes these figures were $25.0 \%, 68.3 \%$ and $6.7 \%$ respectively. In schoolchildren the mean SEP for right $(-0.41 \mathrm{D})$ and left $(-0.42 \mathrm{D})$ eyes showed no difference. In schoolchildren there was no difference between SEP for gender.

Of the 444 right eyes of employees $29.7 \%$ was myopic $>0.50 \mathrm{D}, 60.4 \%$ emmetropic [$0.50 \mathrm{D}$ to $+0.50 \mathrm{D}$ ], and $9.9 \%$ hyperopic $>0.50 \mathrm{D}$; for the left eyes these figures were $26.8 \%, 64.0 \%$ and $9.2 \%$ respectively. In employees the mean SEP for right $(-0.58 \mathrm{D})$ and left eyes $(-0.61 \mathrm{D})$ showed no difference. Also no difference was observed between SEP for age and gender. 
Concerning optical correction it was found that $22 \%$ of the schoolchildren were ametropic $>0.50 \mathrm{D}$ but did not wear an optical correction. In employees $18 \%$ did wear an optical correction with ametropia <0.50D.

Optometric examination/ anisometropia In table 1 also the percentages for anisometropia are listed for schoolchildren and employees.

Anisometropia of $>1.00 \mathrm{D}$ or more was present in $4.6 \%$ of children and $25.2 \%$ of employees.

Employees aged 40-60 years are more often anisometropic than employees aged 17-39 years (Chi square $p=0.02$ and Cramer's $V=0.15$ ). In employees the prevalence of anisometropia was not found to differ according to gender.

Optomethic examination/ correlation between right and left eyes For children the Pearson correlation coefficient ( $r$ ) of SEP between right and left eyes was 0.93 , for sphere component 0.91 and for cylinder component 0.57 . For employees these figures were $0.53,0.51$ and 0.24 , respectively. Figure 1 shows scatter plots of SEP of the right and left eyes for children as well as for employees. Among employees aged 17-60 years, anisometropia was more prevalent than in schoolchildren aged $11-13$ years $(25.2 \%$ versus $4.6 \%)$.

Table 1 The prevalence ${ }^{\circ}$ ) of sphere equivalent power (SEP) of right and left eyes and anisometropla ( of of Dutch schoolchildren (aged 11-13 vears) and hospital employees (aged 17-60 yoars)

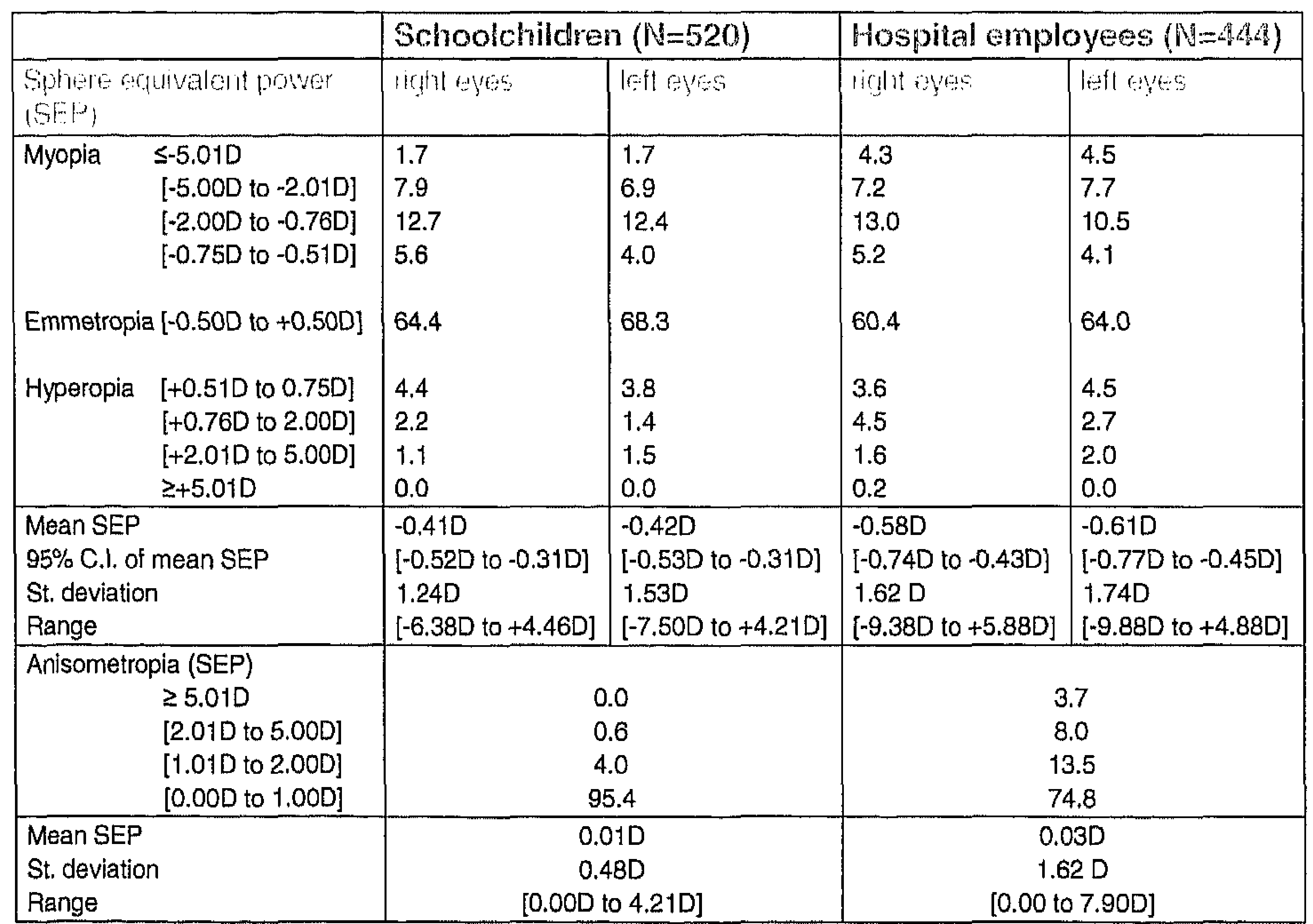


Optometric examination/ cylinder component

In table 2 the percentages for cylinder component of RE of schoolchildren and employees are presented. Of the schoolchildren and the hospital employees a cylinder value $>0.50 \mathrm{D}$ was found for right eyes in $11.9 \%$ and $23.6 \%$, respectively. Mean right eye cylinder for schoolchildren and hospital employees were 0.26D with $95 \%$ C.I [0.23D to $0.30 \mathrm{D}$ ] and $0.35 \mathrm{D}$ with $95 \% \mathrm{C} .1$ [0.29D to $0.41 \mathrm{D}$ ], respectively. For left eyes these figures are comparable.

Figure 1 Scatter plot of spherical equivalent power (SEP) of refractive error of right and left eyes of children (left) and hospital employees (right)

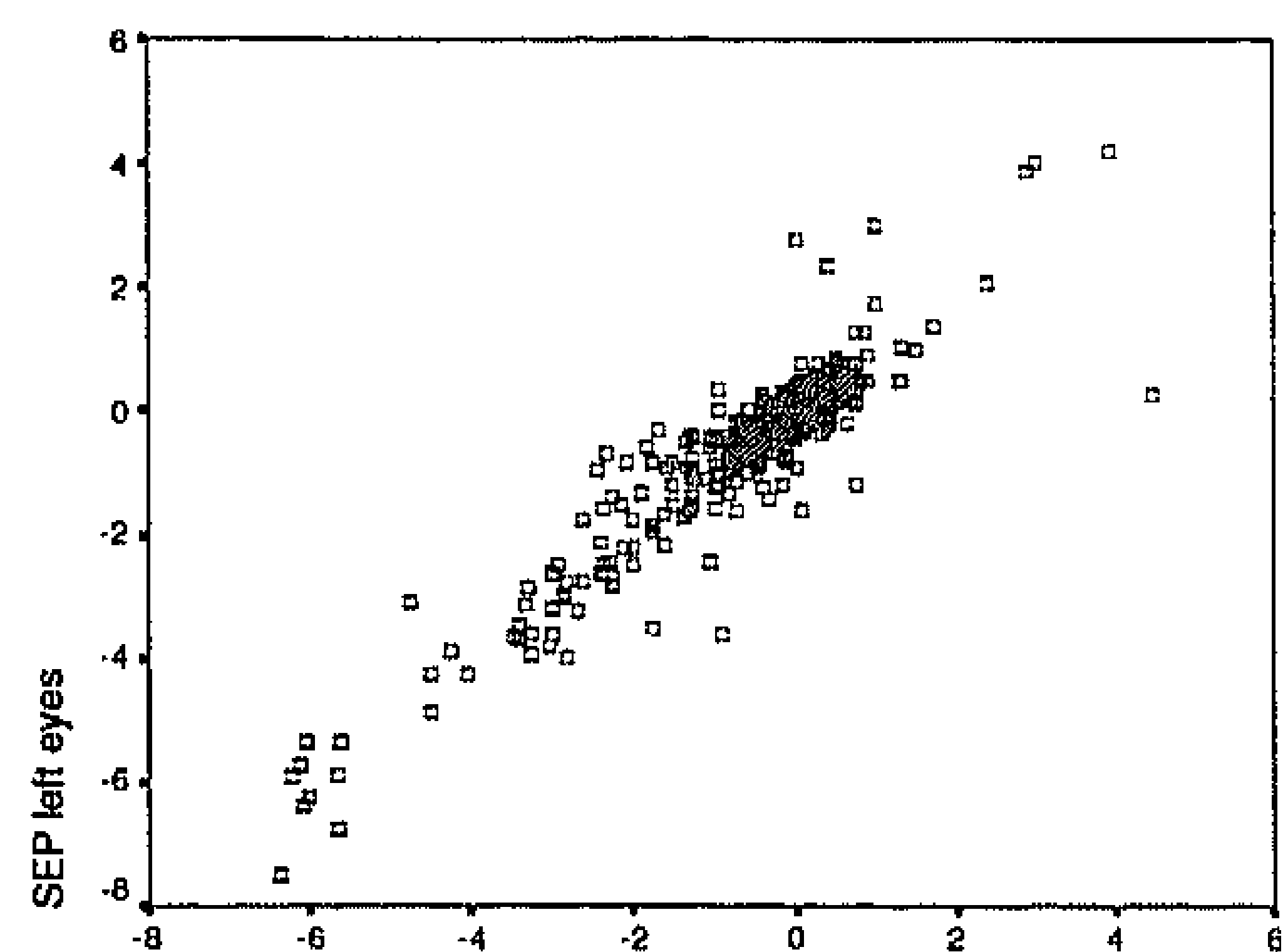

SEP riaht eves

Schoolchildren

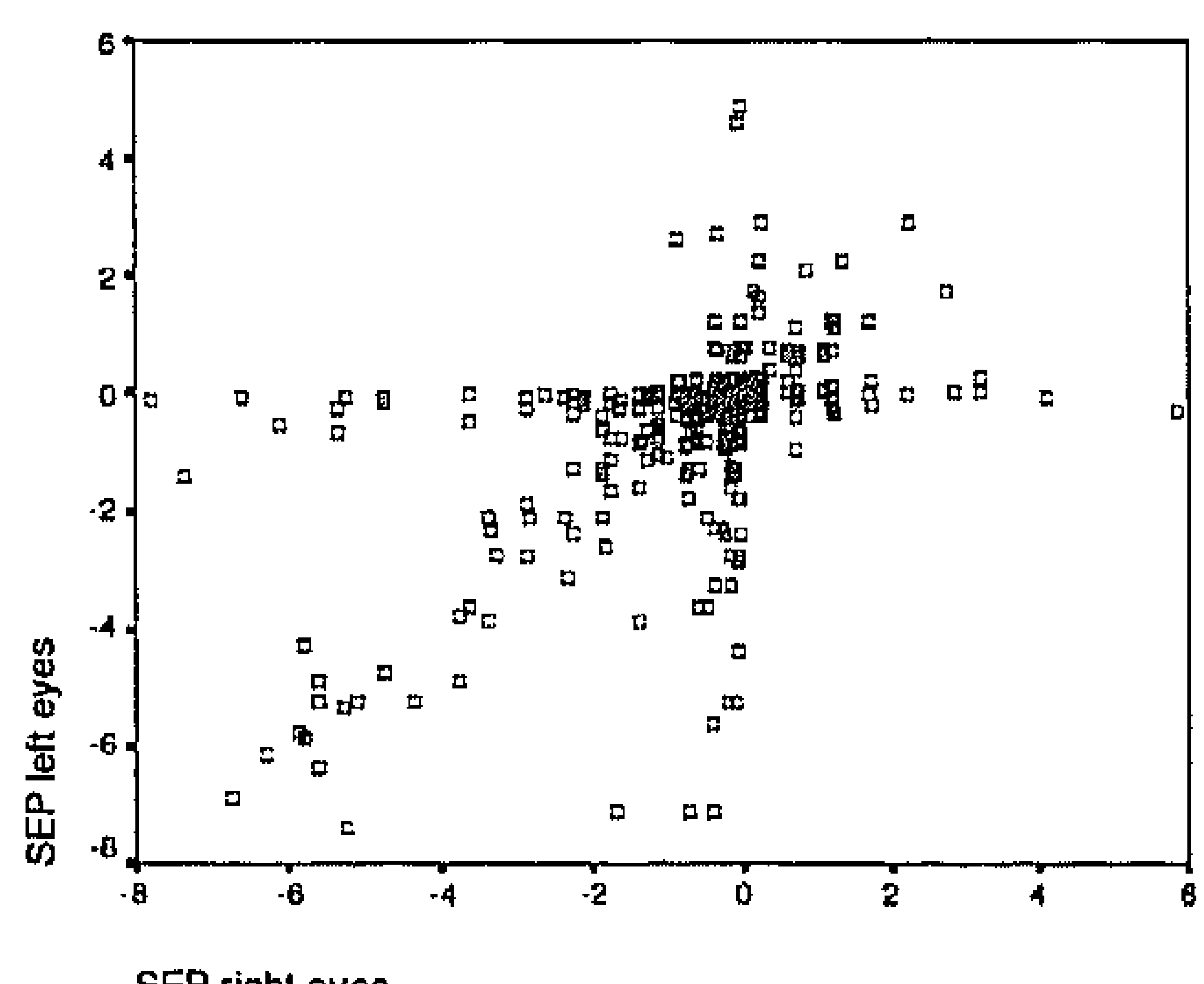

Hospital employees

Table 2 The prevalence $(\%)$ of the astigmatic component of refractive errors of right and left eyes in Dutch school children (aged 11 13 years) and hospital employees (aged 17-60 years).

\begin{tabular}{|l|l|l|l|l|}
\hline \multicolumn{2}{|l|}{} & \multicolumn{2}{l|}{$\begin{array}{l}\text { SCHOOLCHILDREN } \\
(N=520)\end{array}$} & \multicolumn{2}{l|}{$\begin{array}{l}\text { HOSPITAL EMPLOYEES } \\
(N=444)\end{array}$} \\
\hline & right eyes & left eyes & right eyes & left eyes \\
\hline Cylinder & & & & \\
$\leq-5.01 D$ & 0.0 & 0.0 & 0.0 & 0.0 \\
{$[-5.00 \mathrm{D}$ to $-2.01 \mathrm{D}]$} & 0.8 & 1.0 & 3.3 & 2.3 \\
{$[-2.00 \mathrm{D}$ to $-0.76 \mathrm{D}]$} & 4.6 & 4.8 & 20.3 & 19.3 \\
{$[-0.75 \mathrm{D}$ to $-0.51 \mathrm{D}]$} & 6.5 & 6.5 & 0.0 & 0.0 \\
{$[-0.50 \mathrm{D}$ to $-0.26 \mathrm{D}]$} & 21.9 & 23.3 & 0.0 & 0.0 \\
{$[-0.25 \mathrm{D}$ to $0.00 \mathrm{D}]$} & 66.2 & 64.4 & 76.4 & 78.4 \\
\hline Mean cylinder & $-0.26 \mathrm{D}$ & $-0.28 \mathrm{D}$ & $-0.35 \mathrm{D}$ & $-0.33 \mathrm{D}$ \\
95\% C.I. of mean cylinder & {$[-0.30 \mathrm{D}$ to $-0.23 \mathrm{D}]$} & {$[-0.31 \mathrm{D}$ to $-0.24 \mathrm{D}]$} & {$[-0.41 \mathrm{D}$ to $-0.29 \mathrm{D}]$} & {$[-0.38 \mathrm{D}$ to $-0.27 \mathrm{D}]$} \\
St. deviation & $0.39 \mathrm{D}$ & $0.38 \mathrm{D}$ & $0.64 \mathrm{D}$ & $0.57 \mathrm{D}$ \\
Range & {$[-4.50 \mathrm{D}$ to $0.00 \mathrm{D}]$} & {$[-3.00 \mathrm{D}$ to $0.00 \mathrm{D}]$} & {$[-5.75 \mathrm{D}$ to $0.00 \mathrm{D}]$} & {$[-4.25 \mathrm{D}$ to $0.00 \mathrm{D}]$} \\
\hline
\end{tabular}




\section{DISCUSSION}

In right eyes, myopia $>0.50 \mathrm{D}$ was found in $27.9 \%$ of schoolchildren and in $29.7 \%$ of employees; hyperopia $>0.50 \mathrm{D}$ in $7.7 \%$ of schoolchildren and in $9.9 \%$ of employees. These differences in prevalence of RE between schoolchildren and employees were not statistically significant. Although prevalence rates are not as high as reported in Asian studies, prevalence rates found in the Netherlands are relatively high, and similar to Scandinavian prevalences. RE are becoming more of a problem in many societies, with prevalence rates of myopia in many Asian urban countries reaching epidemic proportions. ${ }^{8}$

In most optometric papers the degree of ametropia is defined rather arbitrarily. We listed SEP of $<-0.50 \mathrm{D}$ as myopia, and SEP of $>+0.51 \mathrm{D}$ as hyperopia. In daily practice cut-off points for RE might be defined differently, depending on the clinical goals. Low degree RE might not influence visual acuity substantially, but these errors might be useful in eliminating functional problems and aspecific health complaints.

It is remarkable that in employees, anisometropia was substantially more prevalent than in schoolchildren ( $25.2 \%$ vs. $4.6 \%$ ). This difference is also expressed by the lower Pearson correlation coefficient ( $r$ ) of sphere equivalent between right and left eyes in employees $(r=0.53)$ versus schoolchildren $(r=0.93)$. We were surprised by this finding at the moment of data evaluation, but recently we became aware of comparable results in a study by Qin et $\mathrm{al}^{26}$, who reported an independent association between anisometropia and both spherical ametropia and astigmatism. Their results also suggested an increased prevalence of anisometropia with age. The prevalence of ametropia $>1.00 \mathrm{D}$ in their cohort increased from $10 \%$ in teenagers to $30 \%$ in people eighty years and older. Possible consequences for this amount of anisometropia on daily functioning have not yet been investigated.

Autorefractors give quick and accurate readings of refractive error without examiner bias or the involvement of highly trained clinical personnel. ${ }^{27,28}$ Accommodation reduces the validity and reliability of the instrument ${ }^{28,29}$, because noncycloplegic measurements tend to underestimate the hyperopic status. Because our aim was to evaluate the children under conditions as close as possible to those under which they usually function (habitual RE), the use of a cycloplegium was contra-indicated. Cycloplegia is a method to detect latent hyperopia or pseudo-myopia, but it does not yield adequate information on habitual $R E$, with this we realize that we measure a different concept than "true" (or absolute) RE.

A question that can be asked is whether a selection bias could have been introduced. We consider this unlikely. For the schoolchildren the response rate was very high and the reasons for not participating were not related to refractive error. Part of the group of employees were on sickness leave or were working on night shift and many others had practical or logistic reasons not to participate; however, we have no reason to assume that non-participation was related with refractive status. 
Of the schoolchildren $22 \%$ were ametropic more than $0.50 \mathrm{D}$ but did not wear an optical correction, while $18 \%$ of employees did wear an optical correction although their ametropia was less than 0.50D. In the employees this can be explained by the use of bifocal- or multifocal glasses with low correction for distance. But in children it means that many eyes are not optimally corrected.

\section{CONCLUSION}

Refractive errors are common in schoolchildren aged $11-13$ years and in hospital employees aged 17-60 years. Distribution of sphere and cylinder are similar between school children and employees in the Netherlands. The prevalence of anisometropia is substantially higher in employees than in schoolchildren. Among older employees anisometropia proved to be more prevalent than in younger employees. Especially in children, increased attention should be paid to uncorrected and miscorrected refractive errors.

Conflict of interest statement

We declare that we have no conflict of interest.

Role of the funding source

This study was an academic project involving different disciplines in the Maastricht University; there was no external funding source. The corresponding author had full access to all the data in the study and had final responsibility for the decision to submit for publication.

\section{Acknowledgements}

The authors thank the schoolchildren and the employees who participated in this study. Our gratitude also goes to the former Ambiorix Organization (nowadays the Ambiorix Organization is merged into the INNOVO foundation) and the Atrium Medical Centre (a general hospital in Heerlen, the Netherlands) for their help and logistic support in data collection. 


\section{REFERENCES}

1 Taylor HR, Keeffe JE, Vu HT, Wang JJ, Rochtchina E, Pezzullo ML, Mitchell P. Vision loss in Australia. Med J Aust. 2005 Jun 6;182(11):565-8.

2 Fredrick DR. Myopia. BMJ 2002;324:1195-1199.

3 Saw SM, Gazzard G, Shin-Yen EC, Chua WH; Myopia and associated pathological complications. Opthalmic Physiol. Opt. 2005 Sep 25(5):381-91.

4 Tokoro T. Atlas of posterior fundus changes in pathologic myopia. Tokyo Inc.:SpringerVerlag; 1988.

5 Headache Classification Committee of the International Headache Society. Classification and diagnostic criteria for headache disorders, cranial neuralgias and facial pain. Cephalalgia. 1988;8(suppl. 7):1-96.

6 Eckhardt, L.B., McLean, J.M., Goodell, H., Experimental studies on headache: the genesis of the eye. Proc. Assoc. Res. Nerv. Ment. Dis. 1943:209-227.

7 Ting PW, Lam CS, Edwards MH, Schmid KL. Prevalence of myopia in a group of Hong Kong microscopists. Optom Vis Sci. 2004 Feb;81(2):88-93.

8 Lam CS, Goldschmidt E, Edwards $\mathrm{MH}$. Prevalence of myopia in local and international schools in Hong Kong. Optom Vis Sci. 2004;81:317-322.

9 Kempen JH, Mitchell P, Lee KE, Tielsch JM et al. The prevalence of refractive errors among adults in the United States, Western Europe, and Australia. Arch Opthalmol. 2004Apr;122(4):495-505.

10 Park DJ, Congdon NG. Evidence for an "epidemic" of myopia. Ann Acad Med Singapore. 2004 Jan;33(1):21-6.

11 Fan DS, Lam DS, Lam RF, Lau JT, Chong KS, Cheung EY, Lai RY, Chew SJ. Prevalence, incidence, and progression of myopia of school children in Hong Kong. Invest Ophthalmol Vis Sci. 2004 Apr;45(4):1071-5.

12 Midelfart, A., Kinge B., Midelfart S.\& Lydersen S. Prevalence of refractive errors in young middle-aged adults in Norway. Acta Ophthalmo. Scand. 2002 Oct;80(5): 501-505.

13 Junghans BM, Crewther SG. Prevalence of myopia among primary school children in eastern Sydney. Clin Exp Optom. 2003; 86(5):339-45.

14 Lavery, J.R., Gibson, J.M., Shaw, D.E., \& Rosenthal, A.R. Refraction and refractive errors in an elderly population. Ophthal Physiol. Opt. 1988;8(4):394-396. Lin LL, Shih YF, Hsiao CK, Chen CJ, Lee LA, Hung PT. Epidemiologic study of the prevalence and severity of myopia among schoolchildren in Taiwan in 2000. J Formos Med Assoc. 2001;100(10): 684-91.

16 Kuo A, Sinatra RB, Donahue SP. Distribution of refractive error in healthy infants. $J$ AAPOS. 2003;7(3):174-77.

17 Villarreal, M.G., Ohlsson J., Abrahamsson M., Sjöström A., Sjöstrand J. Myopisation: The refractive tendency in teenagers. Prevalence of myopia among young teenagers in Sweden. Acta Ophthalmol Scand. 2000Apr;78(2):177-181.

18 Dayan YB, Levin A, Morad Y, Grotto I, Ben-David R, Goldberg A, Onn E, Avni I, Levi Y, Benyamini $O G$. The changing prevalence of myopia in young adults: a 13-year series of population-based prevalence surveys. Invest Ophthalmol Vis Sci. 2005Aug;46(8):2760-5.

19 Grosvenor T. Why is there an epidemic of myopia? Clin Exp Optom. 2003 Sep;86(5):273-5.

20 E. Aine. Refractive errors in a rural Finnish population. Acta Opthalmol.1984 Dec; 62(6):944-954.

21 Wu S-Y, Yoo YJ, Nemesure B, Hennis A, Leske MC. Nine-year refractive changes in the Barbados eye studies. Invest Ophthalmol Vis Sci. 2005 Nov;46(11):4032-4039. Jiang BC, Schatz $S$, Seger K. Myopic progression and dark focus variation in optometric students during the first academic year. Clin Exp Optom. 2005 May;88(3):153-9. Rose K, Smith W, Morgan I, Mitchell P. The increasing prevalence of myopia: implication for Australia. Clin Exp Ophthalmol. 2001;29:116-120.

24 Pararajasegaram R. Vision 2020 - the right to sight: from strategies to action. Am J Ophthalmol 1999;182:359-60. 

associations of anisometropia and aniso astignatism in a population based sample of year old children. Br J Opthalmol 2006:90 597-601.

26 Qin X.J, Margrasn TH. To CH. Bromham N, Guggenhem JA Anisometropia is independently associated with both spherical and cylindrical ametropia. Invest Ophthalmol Vis Sci. 2005 Nov;46(11):4024-4031

27 El-Defrawy S. Clarke WN. Belec F. Pham B. Evaluation of a handheld autorefractor in children younger than 6. J Pediatr Ophthalmol Strabismus. 1998;35(2):107-9.

28 Harvey, E. M. Miller, J.M. Dobson, V., Tyszko, K. \& Davis, A.L. Measurement of refractive error in Native American preschoolers: validity and reproducibility of autorefraction. Optom Vis Science. 2000 Mar:77(3):140-149.

29 Wesemann W, Dick B. Accuracy and accommodation capability of a handheld autorefractor. Journal Cataract Refractive Surgery. 2000 Jan;26(1):62-70 


\title{
Chapter 4
}

Relationship between habitual refractive errors and headache complaints in schoolchildren

\author{
Theo J.W. Hendricks \\ John de Brabander ${ }^{2}$ \\ Frans G. van der Horst ${ }^{1.3}$ \\ Fred Hendrikse ${ }^{2}$ \\ J. André Knottnerus ${ }^{1.3}$
}

Published in: Optometry and Vision Science 2007;84:137-143

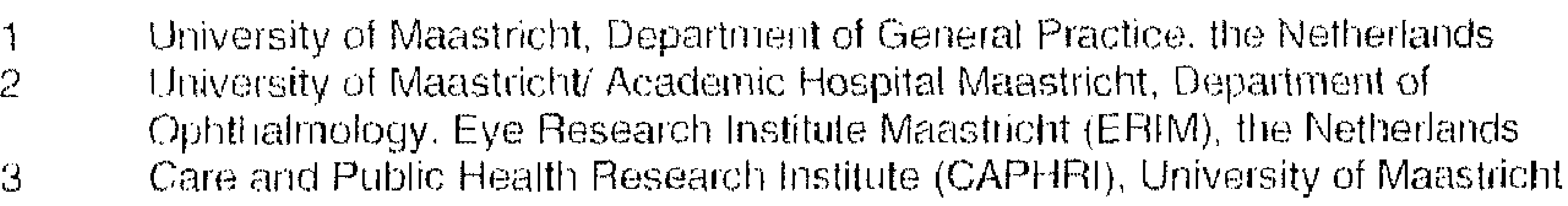




\section{Relationship between refractive errors and headache complaints in schoolchidren}

\section{ABSTRACT}

Purpose Refractive error (RE) is considered to be a possible cause for headaches. We aimed to gain insight into the relation between habitual RE (sphere and astigmatism) and headache complaints.

Methods In a cross-sectional study the habitual refractive state of 487 children, aged between 11 and 13 years, was measured using an autorefractometer (Topcon, RM-8000B). Headache complaints were measured using a questionnaire. Data were analysed using Pearson correlation coefficients, bivariate analysis, and multiple logistic regression analysis.

Fiesults For right eyes we found $15 \%$ habitual myopia $<-0.50 \mathrm{D}$ and $12 \%$ habitual hyperopia $>+0.50 \mathrm{D}$; habitual astigmatism $>0.25 \mathrm{D}$ was found in $33 \%$ of children. Pearson $\mathrm{R}$ between right and left eyes was 0.76 for the spherical component and 0.42 for the cylindrical.

In the total group of children $70 \%$ reported the occurrence of headache in the last year. These headaches were reported as "often or frequent" by $37 \%$ of children, "severe" by $15 \%$, "with long duration" by $45 \%$, and "with severe burden" by $27 \%$.

In the total sample we found various associations between gender, sphere/cylinder components of habitual RE, and headache complaints. Headache was reported more in girls than in boys. Of the total variance of headache complaints in girls, the sphere component of habitual RE explained $4 \%$ of frequency, $6 \%$ of intensity, $2 \%$ of duration, and $2 \%$ of amount of burden. Of the total variance of headache complaints in boys the cylinder component of habitual RE explained $3 \%$ of frequency, and $4 \%$ in amount of burden.

Conclusion Habitual RE and headache complaints are relatively common conditions in schoolchildren aged between 11 and 13 years. Headache complaints showed a small but statistically significant association with the sphere component of habitual RE in girls and the cylinder component of habitual RE in boys. The associations found between habitual RE and headache complaints, indicates that habitual RE might be a risk factor for headache in children.

Keywords Refractive error, astigmatism, headache, gender, schoolchildren. 


\section{INTRODUCTION}

Headache is an important cause of health complaints and disability worldwide.

Epidemiological studies in the general population of developed countries have shown an occurrence of sporadic headache in $40 \%$ and of chronic primary headaches in $15 \%$ (migraine, and tension-type headache). ${ }^{1}$ Every day, a million people in European countries have a migraine attack, and an estimated 100 million workdays or schooldays per year are lost because of migraine. ${ }^{2}$ Episodic tension-typeheadache - "normal" or "ordinary" headache - is less disabling but more prevalent than migraine. ${ }^{3}$ Headache can impair job productivity and reduce quality of life. Due to lost workdays, headache has serious socio-economic impact. ${ }^{4}$ Many affected people are reluctant to seek medical treatment. Most people with tension-type headache manage themselves. ${ }^{5}$ A recent study found that $60 \%$ of people reporting severe headaches used only over-the-counter medication. ${ }^{6}$

The proportion of refractive errors (RE) in the general population ranges from $13 \%$ to $80 \%$ in various studies. In different geographic areas and different age groups prevalence rates vary substantially. ${ }^{7 \cdot 10}$

Although not based on firm evidence, uncorrected RE (especially hyperopia) is considered to be a possible cause for headache. ${ }^{11-13}$ The criteria for the classification of headache of the International Headache Society (IHS) include an entity Headache Associated with Refractive Errors (HARE), but it is indicated that its importance is widely overestimated. ${ }^{14}$ In 2002 Gil-Gouveia ${ }^{12}$ reported an association between hyperopia and HARE in healthy subjects with uncorrected or miscorrected RE compared to a control group. Although in the literature several possible ophthalmic causes for headache are mentioned, it remains unclear how to explain a possible causal relation. In 1966, Gordon ${ }^{15}$ claimed that minor RE often caused more headache and symptoms of eyestrain than major RE. Ciliary muscle strain has also been suggested as possible source of headache. ${ }^{16}$ Another proposed mechanism is 'brow furrowing', implying that prolonged contraction of the brow, scalp and neck muscles in an attempt to maintain a clear image results in headache. ${ }^{17}$

Normally in prevalence studies RE is measured using subjective or objective methods, with and/or without the use of cycloplegia. In relation to complaints like headache it is not the absolute RE, rather than the RE that remains with or without correction, which might be of importance. This defined as habitual RE. Because headache is a serious burden and as the role of habitual RE in the occurrence of headache is still unclear, the objective of the present study was to gain insight into the relation between habitual RE (sphere and astigmatism) and selfreported headache complaints in children aged between 11 and 13 years. 


\section{MATERIALS \& METHODS}

Design. Research Model and Study Population

The present study has a cross-sectional design. We investigated whether reported headache complaints are associated with habitual RE (sphere and cylinder components), and whether these possible associations were modified by gender. Twenty-one primary schools in the southern part of the Netherlands were approached. The children in their last year of primary school (aged between 11 and 13 years) were asked to participate in this study. The teachers of the schools distributed the study information to the children and their parents. The research followed the tenets of the Declaration of Helsinki, and informed consent was obtained from the parents after explanation of the nature and possible consequences of the study. Participation comprised a measurement of the RE of the eyes of the children with an autorefractometer in May 2003. Questionnaires asking for details of headaches were completed by the children. In order to facilitate participation the measurements took place during school time.

\section{SUFVEY MEASURES}

Habitual Refractive Errors (habitual RE)

Habitual RE of both eyes were measured using an autorefractometer (Topcon RM$8000 \mathrm{~B}$ ). Spherical and astigmatic deviations were measured to the nearest $0.25 \mathrm{D}$.

Astigmatic axes were measured to the nearest five degrees, negative cylinders being used for all measurements. Because the measurements involved the habitual RE the use of a cycloplegium was not indicated. Children normally wearing an optical correction were measured with their glasses or contact lenses (habitual RE). The autorefractor as used in the data collection has an automatic analysis system for image quality. If (e.g. by reflection from spectacle lenses) the image quality is too low, the instrument will display this measurement as an error.

Each eye was measured three times, of which the average was taken. All examinations were carried out by the same observer, who did not know the results of the headache questionnaire of each child. Right eyes were always measured before left eyes In most optometric studies the degree of ametropia is defined rather arbitrarily. For optical reasons low degrees of ametropia are relatively unimportant. In our case low degrees of ametropia were included since especially these might be of importance in relation to headaches. ${ }^{15}$ Using the spherical part of the refraction, the children were placed in three categories: myopia < -0.50D, emmetropia [-0.50D to +0.50D], and hyperopia $>+0.50 \mathrm{D}$. Astigmatism was categorized in two groups: children without astigmatism $[0.00 \mathrm{D}$ to $0.25 \mathrm{D}]$ and with astigmatism $>0.25 \mathrm{D}$.

\section{Headache Questionnaire}

Headache characteristics were assessed using an adapted version of Waters' Headache Questionnaire (WHQ). ${ }^{18-20}$ Headache intensity was measured using a Visual Analogue Scale (VAS) of the Paediatric Pain Assessment Tool (PPAT). ${ }^{21-23} \mathrm{~A}$ so called $V A S^{24}$ is a psychometric single-item measurement scale represented on a continuous line ranging from 0 to 100 millimetre $(\mathrm{mm})$. The children were asked to mark the level of their headache intensity ("usual headache" and "worst headache") 
on this line. Headache burden was measured using a 5-points Likert scale, ranging from "I am only aware of it when I pay attention to it" to "headache: such that I can't do anything". 25

If a child reported in the questionnaire to have suffered from the mentioned headache, she or he was counted as a case for this item. Children were assessed, according to Bentzen's modified definition of a health problem: "any concern in relation to health of a person determined by the person". ${ }^{26}$ Key items were frequency, intensity, duration and amount of burden due to these headache episodes.

For use in logistic regression analysis the scores on the headache scales were dichotomized. A higher category means a higher degree of complaints. The high frequency headache group (often) consisted of children with headache frequency of once a week or more often, the high intensity group (severe) had a usual headache intensity of at least $50 \mathrm{~mm}$ on the VAS, and in the long average duration group (long) headache duration usually lasted more than an hour. Children scoring 4 or 5 on a 5points Likert scale were categorized within the severe burden group (severe).

Data Analysis

Data were analysed with the Statistical Package for Social Sciences (SPSS) version 10.0. Pearson correlation coefficient was used to analyse correlations between right and left eye measurements.

Differences in the prevalence of headache complaints and habitual RE (sphere and cylinder) between the genders and optical correction subgroups were analysed by Pearson Chi-square tests, supplied by Cramer's V association measures. Cramer's V ranges from 0 (no association) to 1 (perfect association).

In order to assess the influence of five independent variables (age, gender, wearing of glasses, sphere and cylinder) simultaneously on headache complaints as dependent variable; we used multiple logistic regression analysis (stepwise criteria probability-to-enter $\leq 0.05$, and probability-to-remove $\geq 0.10$ ). Odds ratios were calculated to quantify the association between children's habitual RE and reported headache complaints. Because of multicollinearity, right and left eye information was used separately. To estimate the proportion of variance in the dependent variable which is explained by the predictor (independent) variables we used the Nagelkerke $\mathrm{R}$-squared. This test is an adjusted version of the Cox \& Snell R-squared. ${ }^{27}$

\section{PESULTS \& ANALYSIS}

\section{Study Population}

Nineteen of the 21 primary schools approached in the southern part of the Netherlands agreed to participate. Of the 588 children in the participating schools, 487 children $(83 \%)$ actually participated in the present study. Non-participation was due to absence/illness (37 children; $6 \%$ ), no permission of the parents (29 children; $5 \%$ ), questionnaires not (correctly) filled out ( 35 children; $6 \%$ ). In this group of schoolchildren ( $N=487$, aged $11-13$ years), more girls took part in the study than boys ( 252 girls; $52 \%$, and 235 boys; $48 \%)$. Of the 487 children, $74(15 \%)$ were optically corrected. Boys were slightly less often optically corrected than girls (14\% versus $17 \%)$. 
Refractive Examination

Prevalence of habitual RE is presented in table 1. A quarter of the children proved to have habitual spherical RE $> \pm 0.50 \mathrm{D}$. One third of the children showed habitual cylindrical RE > 0.25D.

Pearson correlation coefficients between right and left eyes for all children were 0.76 $(p<0.01)$ for the sphere component and $0.42(p<0.01)$ for the cylinder component. In boys with glasses sphere and cylinder components of habitual RE were significantly more prevalent $(p<0.01)$, than in boys without glasses. For the sphere and cylinder components of habitual RE, Cramer's V showed to be 0.31 and 0.20 respectively.

In girls with glasses cylinder components of habitual RE were significantly $(p=0.01)$ more prevalent than in girls without glasses (Cramer's $V=0.16$ ).

The only significant difference in prevalence of habitual RE between girls and boys was found in the sphere component for left eyes of children with glasses $(p=0.03$; Cramer's $V=0.31$ ). Compared to girls with glasses, boys with glasses proved to have in left eyes more often myopia ( $41 \%$ vs. $19 \%$ ) and more hyperopia ( $16 \%$ vs. $7 \%$ ).

Table 1 Prevalence of habitual refractive enor of hith and left eyes related to gender and optical correction $(N=437) . M=$ myopia. $E=$ ommetroph. $H=$ hyperopia. $Y$ astigmatism. N= No astigmatism. With glasses $=$ children nomally wearing glasses.

\begin{tabular}{|c|c|c|c|c|c|c|}
\hline & & \multicolumn{5}{|c|}{ Prevalence of refractive error } \\
\hline & & $\begin{array}{l}\text { Total goun } \\
\text { of ebildren } \\
\qquad v=487\end{array}$ & $\begin{array}{c}\text { Boys } \\
\text { with } \\
\text { glasses } \\
\text { No=32 }\end{array}$ & $\begin{array}{l}\text { Boys } \\
\text { without } \\
\text { glasses } \\
M=203\end{array}$ & $\begin{array}{c}\text { Girls } \\
\text { with } \\
\text { glasses } \\
N=42\end{array}$ & 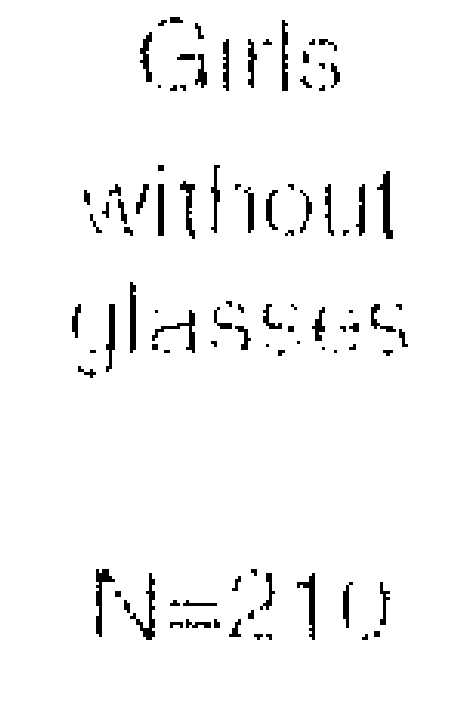 \\
\hline $\begin{array}{l}\text { Right eye sphere } \\
\text { component }\end{array}$ & $\begin{array}{l}M \\
E \\
H\end{array}$ & $\begin{array}{c}72(15 \%) \\
358(73 \%) \\
57(12 \%)\end{array}$ & $\begin{array}{c}12(38 \%) \\
14(44 \%) \\
6(19 \%)\end{array}$ & $\begin{array}{c}21(10 \%) \\
164(81 \%) \\
18(9 \%)\end{array}$ & $\begin{array}{c}10(24 \%) \\
26(62 \%) \\
6(14 \%)\end{array}$ & $\begin{array}{c}29(14 \%) \\
154(73 \%) \\
27(13 \%)\end{array}$ \\
\hline $\begin{array}{l}\text { Left eye sphere } \\
\text { component }\end{array}$ & $\begin{array}{l}M \\
\mathrm{E}\end{array}$ & $\begin{array}{c}71(15 \%) \\
373(76 \%) \\
43(9 \%)\end{array}$ & $\begin{array}{c}13(41 \%) \\
14(44 \%) \\
5(16 \%)\end{array}$ & $\begin{array}{c}23(11 \%) \\
165(81 \%) \\
15(7 \%)\end{array}$ & $\begin{array}{c}8(19 \%) \\
31(74 \%) \\
3(7 \%)\end{array}$ & $\begin{array}{c}27(13 \%) \\
163(78 \%) \\
20(10 \%)\end{array}$ \\
\hline $\begin{array}{l}\text { Right eye cylinder } \\
\text { component }\end{array}$ & $\begin{array}{l}Y \\
N\end{array}$ & $\begin{array}{l}159(33 \%) \\
328(67 \%)\end{array}$ & $\begin{array}{l}18(56 \%) \\
14(44 \%)\end{array}$ & $\begin{array}{c}57(28 \%) \\
146(72 \%)\end{array}$ & $\begin{array}{l}21(50 \%) \\
21(50 \%)\end{array}$ & $\begin{array}{c}63(30 \%) \\
147(70 \%)\end{array}$ \\
\hline $\begin{array}{l}\text { Left eye cylinder } \\
\text { component }\end{array}$ & $\begin{array}{l}Y \\
N\end{array}$ & $\begin{array}{l}173(36 \%) \\
314(64 \%)\end{array}$ & $\begin{array}{l}19(59 \%) \\
13(41 \%)\end{array}$ & $\begin{array}{c}63(31 \%) \\
140(69 \%)\end{array}$ & $\begin{array}{l}23(55 \%) \\
19(45 \%)\end{array}$ & $\begin{array}{c}68(32 \%) \\
142(68 \%)\end{array}$ \\
\hline
\end{tabular}

Reported Headaches and Gender and Wearing of Glasses

Seventy percent of all children reported headache complaints in the last year. Table 2 shows that $37 \%$ of children reported the frequency as often (once a week or more often). The intensity of the headache was scored as severe (at least $50 \mathrm{~mm}$ on the VAS) in $15 \%$ of cases. The average duration of headaches lasted in $45 \%$ of cases longer than an hour. Most children (73\%) reported their headaches as a minor burden (scoring 1,2 or 3 on a 5 -point Likert scale). 
Table $2 \quad$ Numbers and percentages of reported headache complaints by schoolchildren and Pearson Chi-square tests for comparing differences in prevalence between subgroups for gender and wearing of an optical conection $(N=487)$.

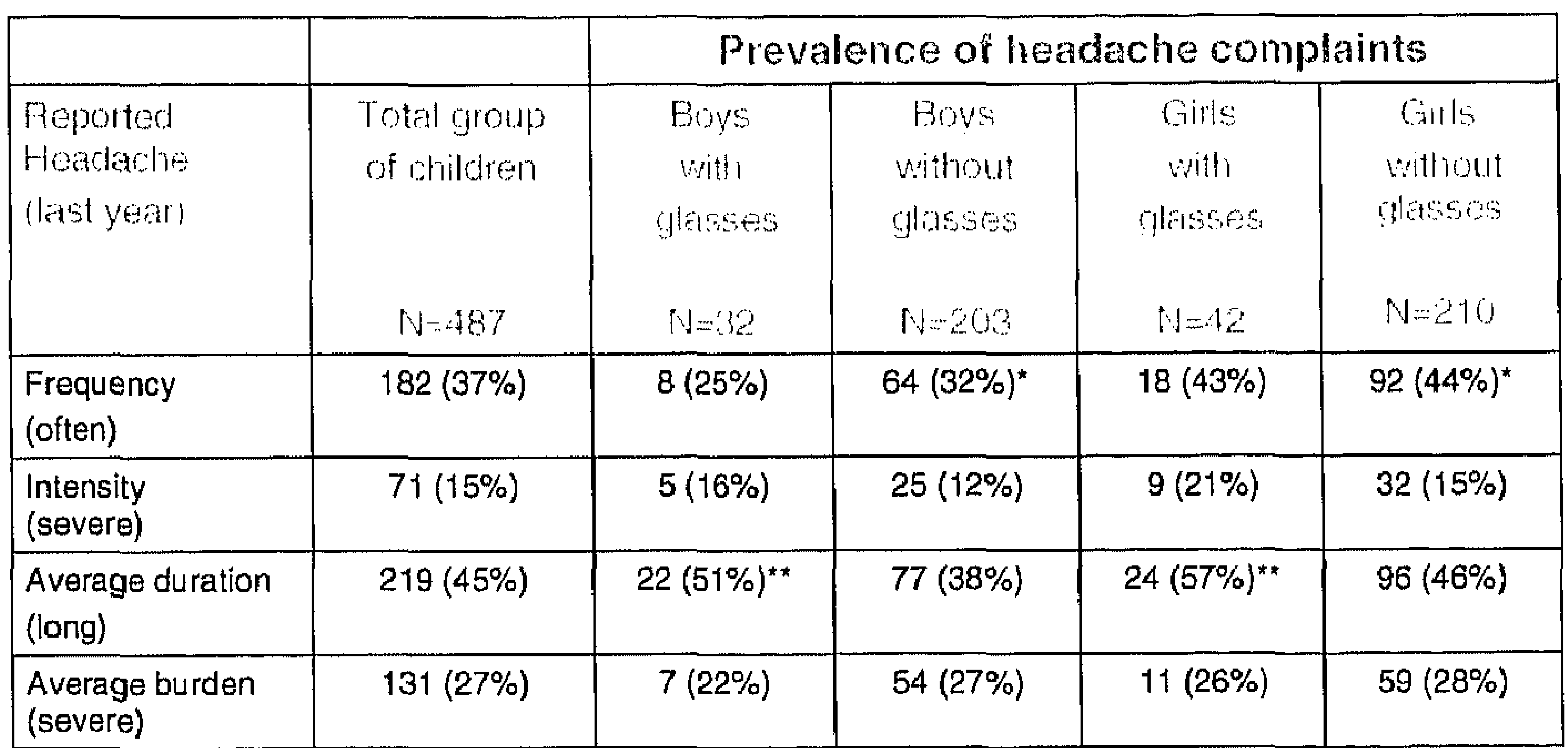

- Difference in prevalence of headache between boys without glasses and girls without glasses $\rho=0.01$ (Cramer's $V=0.13$ ).

** Difference in prevalence of headache between boys with glasses and girls with glasses $p=0.05$ (Cramer's $V=0.23$ ).

\section{Logistic regression}

Table 3 presents the multiple logistic analyses indicating the importance of habitual $\mathrm{RE}$ in relation to headache complaints.

In the total sample only gender, sphere and cylinder remained significant variables. Headache was reported more in girls than in boys regarding frequency (Odds Ratio 1.76; 95\% Confidence Interval 1.21-2.57) and duration (OR 1.42; 95\%Cl 1.07-1.88). Sphere component of habitual RE was associated with frequency (OR 1.60; $95 \% \mathrm{Cl}$ 1.17-2.19), intensity (OR $1.64 ; 95 \% \mathrm{Cl} 1.11-2.42$ ), duration (OR $1.50 ; 95 \% \mathrm{Cl} 1.05$. 2.16 ), and amount of burden (OR 1.51;95\% Cl 1.09-2.09). Cylinder component of habitual RE was associated with frequency (OR 2.01; 95\% $\mathrm{Cl} 1.07-3.78$ ), and amount of burden (OR $2.71 ; 95 \% \mathrm{Cl} 1.25-5.89$ ).

In boys the cylinder component of habitual RE of right eyes is associated with frequency (OR 2.96; 95\% $0.97-9.02$ ) and amount of burden (OR 4.14; $95 \% \mathrm{Cl} 1.18$ 14.55). The cylinder component of RE in boys explained $3-4 \%$ of the total variance in the relation to headache complaints (Nagelkerke R-squared).

In girls the spherical component of habitual RE of right eyes was associated with frequency (OR 1.63; 95\%Cl 1.09-2.42), intensity (OR 2.04;95\%Cl 1.20-3.46), duration (OR 1.47; 95\% Cl 1.01-2.14) and amount of burden (OR 1.45; 95\% $0.97-$ 2.16). Of the total variance in the relation to headache complaints (Nagelkerke Rsquared), the sphere component of habitual RE in girls explained $2-6 \%$. 
Table 3 Relation between gender. habitual refractive error sphere and cylinder component) and headache complaints. Logistic regression analysis and Nagelkerke F-squared. Each sepalate cell of the table shows a reduced model for the relatronshy betreen the dependent and the presented independent vandes Odds latios (and $95^{\circ}$ confidence intervals are presentod for the assochatron between ondrens refractive error and reported headache complaints.

\begin{tabular}{|c|c|c|c|c|}
\hline & & \multicolumn{3}{|c|}{ TOTAL GFOUP } \\
\hline & & $\begin{array}{l}\text { bubapondent } \\
\text { variablas }\end{array}$ & $O . P .48,0,1\}$ & 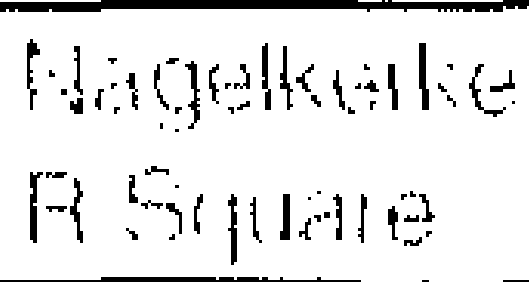 \\
\hline \multirow[t]{4}{*}{ RIGHTEYE } & Frequency & $\begin{array}{l}\text { Gender } \\
\text { Sphere } \\
\text { Cylinder }\end{array}$ & $\begin{array}{l}1.76(1.21-2.57) \\
1.60(1.17-2.19) \\
2.01(1.07-3.78)\end{array}$ & 0.06 \\
\hline & Intensity & Sphere & $1.64(1.11-2.42)$ & 0.02 \\
\hline & Duration & $\begin{array}{l}\text { Gender } \\
\text { Sphere }\end{array}$ & $\begin{array}{l}1.42(1.07-1.88) \\
1.50(1.05-2.16)\end{array}$ & 0.03 \\
\hline & Burden & $\begin{array}{l}\text { Sphere } \\
\text { Cylinder }\end{array}$ & $\begin{array}{l}1.51(1.09-2.09) \\
2.71(1.25-5.89)\end{array}$ & 0.04 \\
\hline \multirow[t]{4}{*}{ LEFTEYE } & Frequency & $\begin{array}{l}\text { Gender } \\
\text { Sphere }\end{array}$ & $\begin{array}{l}1.76(1.21-2.56) \\
1.42(1.05-1.92)\end{array}$ & 0.04 \\
\hline & Intensity & - & - & $\overline{-}$ \\
\hline & Duration & $\begin{array}{l}\text { Gender } \\
\text { Sphere }\end{array}$ & $\begin{array}{l}1.52(1.06-2.18) \\
1.31(0.98-1.74)\end{array}$ & 0.02 \\
\hline & Burden & Sphere & $1.36(0.99-1.88)$ & 0.01 \\
\hline
\end{tabular}

\begin{tabular}{|c|c|c|c|c|}
\hline & & \multicolumn{3}{|l|}{ BOYS } \\
\hline & & $\begin{array}{l}\text { Independent } \\
\text { Varibles }\end{array}$ & $0.8 .196^{\circ} \circ O: 11$ & $\begin{array}{l}\text { Magelketke } \\
\text { PSquate }\end{array}$ \\
\hline \multirow[t]{4}{*}{ RIGHTEYE } & Frequency & Cylinder & $2.96(0.97-9.02)$ & 0.03 \\
\hline & Intensity & - & - &. \\
\hline & Duration & - & $\overline{-}$ & - \\
\hline & Burden & Cylinder & $4.14(1.18-14.55)$ & 0.04 \\
\hline \multirow[t]{4}{*}{ LEFT EYE } & Frequency & - & - & 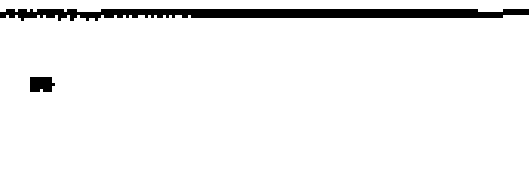 \\
\hline & Intensity & - & - & - \\
\hline & Duration & - & - & - \\
\hline & Burden & - & $\overline{-}$ & $\overline{-}$ \\
\hline
\end{tabular}

\begin{tabular}{|c|c|c|c|c|}
\hline & & \multicolumn{3}{|l|}{ GIRIS } \\
\hline & & $\begin{array}{l}\text { Independent } \\
\text { variables }\end{array}$ & O.R. $195^{\circ} \circ(\mathrm{O})$ & $\begin{array}{l}\text { Nagelkeke } \\
\text { PSquate }\end{array}$ \\
\hline \multirow[t]{4}{*}{ RIGHT EYE } & Frequency & Sphere & $1.63(1.09-2.42)$ & 0.04 \\
\hline & Intensity & Sphere & $2,04(1.20-3.46)$ & 0.06 \\
\hline & Duration & Sphere & $1.47(1.01-2.14)$ & 0.02 \\
\hline & Burden & Sphere & $1.45(0.97-2.16)$ & 0.02 \\
\hline \multirow[t]{4}{*}{ LEFT EYE } & Frequency & Sphere & $1.55(1.00-2.39)$ & 0.02 \\
\hline & Intensity & - & - & - \\
\hline & Duration & $=$ & $\overline{-}$ & $\overline{-}$ \\
\hline & Burden & - & - & - \\
\hline
\end{tabular}




\section{DISCUSSION}

Habitual RE was present in $27 \%$ of schoolchildren aged between 11 and 13 years ( $15 \%$ myopia and $12 \%$ hyperopia). In this study we found in girls an association between the spherical component of habitual RE (especially hyperopia) and headache complaints. In boys the cylinder component of habitual RE of right eyes was associated with frequency of headache occurrence and the amount of burden.

The contribution of right eye habitual $R E$ to headache complaints proved to be different than left eye habitual RE. We have no explanation for this finding. Dominance of right eyes might play a role. In our study the differences found between boys and girls is also remarkable. We have no explanation for the gender differences found in this study. Until now these differences have not been reported in the literature.

In a population with high prevalences of headache and RE one would expect, on chance grounds, many individuals to have both headaches and a RE, but these would not necessarily be etiologically related. ${ }^{11}$ Our results seem to be in accordance with the statement of the Headache Classification Committee of the International Headache Society ${ }^{14}$ that RE contributes significantly to headache complaints, but its contribution is limited, given the low explained variance of $R E$.

Generally, with a cross-sectional designed study causal relations cannot be proven. Normally it is not easy to distinguish whether a variable is cause or effect of the relation found in a study. However, with our subject of investigation it is unlikely that headache complaints cause ametropia or astigmatism. Findings also might be biased due to the mutual interaction of an unknown variable on the variables investigated. Gender and age both are related to RE and headache complaints but we took these factors into account. Other common etiological factors related to both RE and headache complaints were not found in literature. Therefore, in our opinion, it is plausible that the associations we found between ametropia or astigmatism and headache complaints might have a causal significance.

Our study population consisted of Dutch schoolchildren who had reached the last year of study of normal primary school education. The response rate was high. We consider it unlikely that reasons for participation were related to either RE or headache complaints; therefore we have no reason to assume that selection bias has played a role.

Traditionally hyperopia or ciliary muscle strain is referred to as the cause of headache, since accommodation might arouse visual stress. In our study we also found a substantially higher score of headache in hyperopic girls. A role of habitual $\mathrm{RE}$ and ciliary muscle strain in the relation with headache complaints, as mentioned in the introduction, cannot be excluded. ${ }^{15}$

Autorefractors give quick and accurate readings of RE, without examiner bias and without the involvement of highly trained clinical personnel ${ }^{28}$. Accommodation 
reduces the validity and reliability of the instrument ${ }^{29-34}$, because noncycloplegic measurements tend to underestimate the hyperopic status. Because we evaluated the children under conditions as close as possible to those under which they usually function (habitual RE), the use of a cycloplegium was not indicated. Information gained from cycloplegia (to detect latent hyperopia or pseudo-myopia) would not in itself lead to different outcomes because we were interested in categorizing the children according to their habitual refractive state rather than in the absolute levels of their refraction deviations.

The questionnaire asked about headaches over the last year. One could argue that within this period of time refractive error might change, and this might in turn have impact on the results of the study. Indeed small changes in habitual refractive error can occur within this age group. These changes might influence the distribution of children among the categories as used. On the other hand although we asked about headaches over the last year, it is reasonable to assume that headaches over the last weeks are recalled more easily than headaches from a year ago. We think the possible influences of these effects on the study results are minor.

We realize that the prevalence of RE varies enormously in different geographic areas and in ethnic populations. ${ }^{35-38}$ Given that our findings can be generalized to different populations, a substantial number of headache complaints could be avoided.

\section{CONCLUSION}

In this study, the aim was to gain insight into the relation between habitual RE (sphere and astigmatism) and headache complaints. The prevalences of habitual RE and headache complaints in children were relatively high.

In girls the sphere component of habitual RE and in boys the cylinder component of habitual RE was statistically associated with headache complaints, but a very small amount of the variance of headache complaints was explained by the habitual RE. We recommend incorporating measures of RE in the diagnostic process in children with headache complaints.

Conflict of interest statement

We declare that we have no conflict of interest.

Role of the funding source

This study was an academic project involving different disciplines in the Maastricht University; there was no external funding source. The corresponding author had full access to all the data in the study and had final responsibility for the decision to submit for publication.

\section{Acknowledgements}

The authors thank the schoolchildren who participated in this study. Our gratitude also goes to the former Ambiorix Organization for their help and logistic support in data collection (nowadays the Ambiorix Organization has merged into the INNOVO foundation). 


\section{REFERENCES}

1 Lipton RB, Hamelsky SW, Stewart WF. Epidemiology and impact of headache. In: Silberstein SD, Lipton RB, Dalessio DJ, eds. Wolf's headache and other facial pain. $7^{\text {th }}$ ed. Oxford: University Press, 2001:85-107.

2 Steiner TJ, Fontebasso M. Headache. BMJ 2002 Oct;325(7369):881-6.

3 Rasmussen BK, Jensen R, Schroll M, Olesen J. Epidemiology of headache in a general population - a prevalence study. J Clin Epidemiol 1991;44(11):1147-1157.

4 Rasmussen BJ. Epidemiology of Headache. Cephalalgia 2001; Sept 21(7); 774-7.

5 Muelier $L$. Tension-type, the forgotten headache: how to recognize this common but undertreated condition. Postgraduate Medicine 2002 Apr;111(4):25-50.

6 Lipton RB, Diamond S, Reed M, et al. Migraine diagnosis and treatment: results from the American Migraine Study II. Headache $2001 \mathrm{Jul} /$ Aug;41 (7):638-45.

$7 \quad$ Aine E. Refractive errors in a rural Finnish population. Acta Opthalmol 1984 Dec;62(6); 944-54.

8 Kempen JH, Mitchell P, Lee KE, Tielsch JM et al. The prevalence of refractive errors among adults in the United States, Western Europe, and Australia. Arch Opthalmol 2004 Apr;122(4):495-505.

9 Midelfart A, Kinge B, Midelfart S, Lydersen S. Prevalence of refractive errors in Norway. Tidsskr Nor Laegeforen 2004 Jan 8;124(1):46-8.

10 Dandona R, Dandona L, Naduvilath TJ, Srinivas M, McCarty CA, Rao GN. Refractive errors in an urban population in Southern India. Invest Ophthalmol Vis Sci.1999 Nov;40(12):2910-8.

11 Waters WE. Headache and the eye. Lancet 1970 Jul 4;2(7662)1-4.

12 Gil-Gouveia R, Martins IP. Headaches associated with refractive errors: myth or reality? Headache: The Journal of Head and Face Pain 2002 Apr;42(4): 256-62.

13 Gordon GE, Chronicle EP, Rolan P. Why do we still not know whether refractive error causes headaches. Towards a framework for evidence-based practice. Ophthalmic Phys Opt 2001 Jan; 21 (1); 45-50.

14 Headache Classification Committee of the International Headache Society. Classification and diagnostic criteria for headache disorders, cranial neuralgias and facial pain. Cephalalgia 1988; 8 (suppl 7):1-96.

15 Gordon DM. Some headaches in an ophthalmologist's office. Headache 1966 Oct (6):140-145.

16 Eckhardt LB, McLean JM, Goodell H. Experimental studies on headache: the genesis of pain from the eye. Proc Assoc Res Nerv Ment Dis 1943;209- 227.

17 Tanner J. Growth at adolescence. Blackwell Scientific Publications, Oxford, 1962.

18 Passchier J, Orlebeke JF. Headaches and stress in schoolchildren: an epidemiological study. Cephalalgia 1985;5:167-176.

19 Waters WE. Community studies of the prevalence of headache. Headache 1970;1:178186.

20 Moss G, Waters WE. Headache and migraine in a girls' grammar school. In: Waters WE (Ed.). The epidemiology of migraine. Bracknell: Boehringer Ingelheim, 1974, p.49-58. Abu-Saad H. Assessing children's responses to pain. Pain 1984;19:163-171.

22 Huijer Abu-Saad $\mathrm{H}$. Toward the development of an instrument to assess pain in children: Dutch study. In: Tyler DC and Krane EJ, editors. Advances in Pain Research Therapy. Vol.15. Now York: Raven Press Ltd, 1990, p.101-106.

23 Huijer Abu-Saad H, Kroonen E, Halfens R. On the development of a multidimensional Dutch pain assessment tool for children. Pain 1990;43:249-256.

24 van Boer AG, van Lanschot JJ, Stalmeier PF, van Sandick JW, Hulscher JB, de Haes $J C$, Sprangers MA. Is a single-item visual analogue scale as valid, reliable and responsive as multi-item scales in measuring quality of life? Qual Life Res. 2004;13(2):311-20.

25 McGrath PJ, Humphreys P, Keene D, Goodman JT, Lascelles MA, Cunningham SJ, Firestone $P$. The efficacy and efficiency of a self-administered treatment for adolescent migraine. Pain 1992;49:321-324. 
26 Bentzen N, Bridges-Webb C. An international glossary for general/family practice [editorial]. Fam Pract 1995 Sept; 12(3):267.

27 Pallant. (2001). SPSS manual guide.

28 El-Defrawy S, Clarke WN, Belec F, Pham B. Evaluation of a handheld autorefractor in children younger than 6. J Pediatr Ophthalmol Strabismus 1998; 35(2):107-9.

29 Wesemann W, Dick B. Accuracy and accommodation capability of a handheld autorefractor. J Cataract Refract Surg 2000 Jan; 26(1):62-70.

30 Harvey EM, Miller JM, Dobson V, Tyszko R, Davis AL. Measurement of refractive error in Native American preschoolers: validity and reproducibility of autorefraction. Optom Vis Sci 2000 Mar; 77(3): 140-9.

31 Young FA, Leary GA, Box RA, Harris E, Baldwin WR, West DC, Johnson C. Comparison of cycloplegic and non-cycloplegic refractions of Eskimos. Am J Optom Arch $m$ Acad Optom 1971 Oct; 48(10):814-25.

32 Hiatt RL, Braswell R, Smith L, Patty JW. Refraction using mydriatic, cycloplegic, and manifest techniques. Am J Ophthalmol 1973 Nov; 76(5):739-44.

33 Suryakumar $\mathrm{R}$, Bobier WR. The manifestation of noncycloplegic refractive state in preschool children is dependent on autorefractor design. Optom Vis Sci 2003 Aug; 80(8):578-586.

34 Pesudovs $\mathrm{K}$, Weisinger HS. A comparison of autorefractor performance. Optom Vis Sci 2004 Jul; 81(7):554-8. ABSTRACT PUBMED MEDLINE.

35 Lin LL, Shih YF, Hsiao CK, Chen CJ, Lee LA, Hung PT. Epidemiologic study of the prevalence and severity of myopia among schoolchildren in Taiwan in 2000. J Formos Med Assoc 2001 Oct; 100(10): 684-91.

36 Villareal MG, Ohlsson J, Abrahamsson M, Sjöström A, Sjöstrand J. Myopisation: The refractive tendency in teenagers. Prevalence of myopia among young teenagers in Sweden. Acta Ophthalmol Scand 2000 Apr; 78(2):177-81.

37 Kuo A, Sinatra RB, Donahue SP. Distribution of refractive error in healthy infants. $J$ AAPOS 2003 Jun; 7(3): 174-77.

38 Junghans $B M$, Crewther SG. Prevalence of myopia among primary school children in eastern Sydney. Clin Exp Optom 2003 Sept; 86(5):339-45. 


\section{Chapter 5}

Uncorrected refractive errors in schoolchildren are a risk for lower school achievement

Theo J.W. Hendricks ${ }^{1}$

John de Brabander?

Eefje J.M.P. van Oosterhout ${ }^{1}$

Frans G. van der Horst ${ }^{1,3}$

Fred Hendrikse ${ }^{2}$

J. André Knottnerus ${ }^{1.3}$

Submitted for publication 
Uncorrected refractive errors in schoolchildren are a risk
factor for lower school achievement

\section{ABSTRACT}

Purpose Refractive errors might induce lower school achievement. Therefore we investigated the relation between refractive errors (RE) and school achievement.

Methods In a cross-sectional study the habitual refractive state of 464 children, aged 1113 years, was measured using an autorefractometer (Topcon, RM-8000B). School achievement on areas 'language', 'mathematics', 'study skills', and 'world orientation' was measured using the Dutch CITO test. Analysis of variance (ANOVA) was used to investigate the relation between habitual RE and the CITO test scores.

Results High correlations between right and left eyes were found for all optometric measurements. Spherical component of habitual RE revealed prevalences of $13 \%$ for myopia $<-0.50 \mathrm{D}$ and $11 \%$ for hyperopia $>+0.50 \mathrm{D}$. Astigmatism $>0.25 \mathrm{D}$ was found in $59 \%$ of children; of these $58 \%$ showed horizontal/vertical orientation and $42 \%$ oblique orientation.

For the total sample no relation was found between spherical and astigmatic components of habitual RE and school achievement scores. However, spherical ametropic girls not normally wearing an optical correction scored substantially lower than their emmetropic counterparts $(10 \%$ on the total score and $9 \%$ on language). Also, astigmatic boys not normally wearing an optical correction scored lower $(6 \%$ on total score, $8 \%$ on study skills and $7 \%$ on world orientation) than non-astigmatic boys. No relation was found between the orientation of astigmatism and school achievement scores.

Conclusion Girls with spherical ametropia not normally wearing an optical correction and astigmatic children not normally wearing an optical correction performed substantially lower on their school achievement scores. In these children advice for further secondary education proved in general to be one school type level lower. As lower school achievement may be a consequence of small habitual RE, integration of early refraction screening in vision screening programmes might be worthwhile considering.

Keywords Refractive errors, astigmatism, school achievement, gender, schoolchildren. 


\section{INTRODUCTION}

Refractive errors (RE) are highly prevalent in the general population with reported prevalences ranging from $13 \%$ to $80 \%$ in various studies. In different geographic areas and different age groups prevalence rates vary substantially. ${ }^{1-4}$

There is a distinct lack of clarity about the relation between refractive error (RE) and several variables, such as school achievement ${ }^{5,6}$, reading ability ${ }^{7,8}$, intelligence test scores $^{9}$, and reported health problems ${ }^{10}$. Clinical manifestations of the refractive errors myopia and hyperopia differ substantially, In contrast to a myopic person, who has obvious sight complaints at distance, the hyperopic person may complain of 'eyestrain' caused by the effort of accommodation. Besides eyestrain, other symptoms may also have their origin in hyperopia, for instance headache ${ }^{11}$, dizziness, and occasionally nausea ${ }^{12}$. If these factors have secondary effects on school achievement, this could change current screening guidelines, especially for hyperopia.

A growing body of literature on the relationship between RE and intelligence test scores, reading ability and school achievement tends to show that hyperopes, or at least some of them, may have more problems than myopes or emmetropes. ${ }^{13-15}$ Several studies ${ }^{8,9,16-21}$ have shown that hyperopes, on average, achieve lower intelligence test scores than myopes. While these studies do not imply that hyperopes have lower intelligence, their reading ability may be lower than that of myopes.

Knowledge of the possible long-term effects of ignoring refractive errors is necessary to define consistent evidence-based guidelines for optical correction of RE in children. Earlier studies have focused mainly on reading and intelligence differences between myopes and hyperopes, and rarely on the overall school achievement. As far as we know, studies in this field have paid no attention to astigmatism. We have included astigmatism in this study because it may lead to distortion of the retinal image which cannot be compensated by regular accommodation. This would be particularly true for oblique astigmatism. We therefore explored whether children with astigmatism, in particular oblique astigmatism, scored lower on their school achievements than children without astigmatism.

In most optometric studies the degree of ametropia is defined rather arbitrarily. While for optical reasons low degrees of ametropia are relatively unimportant, in relation to school achievement these might be relevant. ${ }^{19}$ Although a number of children has a correction for their ametropia (especially those with high values of ametropia), this does not imply that they are fully corrected to emmetropia. Habitual RE is a term used to describe the state of ametropia a person is dealing with in every day life. The objective of the present study is to gain insight in the relation between habitual $R E$ in a population of unselected schoolchildren aged $11-13$ years, differentiated in to spherical and astigmatic components, and school achievements. 


\section{METHODS}

Design and study population

The present study has a cross-sectional design. We investigated whether school achievements are associated with habitual RE (sphere and cylinder components), and whether these possible associations were different for gender.

Twenty-one primary schools in the southern part of the Netherlands were approached. The children in their last year of primary school (aged between 11 and 13 years) were asked to participate in this study.

The teachers of the schools distributed the study information to the children and their parents. The children participated voluntarily, and their parents were asked for informed consent. Participation comprised a measurement of the habitual RE of the eyes of the children with an autorefractometer in May 2003. In order to facilitate participation the measurements took place during school time. Data on the school achievement test (the CITO test ${ }^{22}$ ) of these children were collected for the year 2003.

\section{SURVEY MEASURES}

Refractive errors

In prevalence studies RE are measured using subjective or objective methods, with and/or without the use of cycloplegia. Because we wanted to evaluate the children under conditions as close as possible to those under which they usually function (habitual RE), the use of a cycloplegium was not indicated. Information gained from cycloplegia (to detect latent hyperopia or pseudo-myopia) would have measured the absolute levels of their refraction deviations rather than their daily habitual RE which they are used to function with during school time hours. In relation to school achievement it is not the absolute RE, rather than the RE that remains with or without correction (this is defined as habitual RE), which might be of importance. Habitual RE of both eyes was measured using an autorefractometer (Topcon RM$8000 \mathrm{~B}$ ). Spherical and astigmatic deviations were measured to the nearest $0.25 \mathrm{D}$. Astigmatic axes were measured to the nearest five degrees, negative cylinders being used for all measurements. Children normally wearing an optical correction were measured with their glasses or contact lenses (habitual RE). The autorefractor as used in the data collection has an automatic analysis system for image quality. If (e.g. by reflection from spectacle lenses) the image quality is too low, the instrument will display this measurement as an error.

Each eye was measured three times, of which the average was taken. All examinations were carried out by the same observer, who did not know the school achievement scores of each child. Right eyes were always measured before left eyes

Using the spherical part of the refraction, the children were placed in three categories: myopia <-0.50D, emmetropia [-0.50D to +0.50D], and hyperopia > $+0.50 \mathrm{D}$. Astigmatism was categorized in two groups: children without astigmatism $[0.00 \mathrm{D}$ to $0.25 \mathrm{D}]$ and with astigmatism $>0.25 \mathrm{D}$.

The orientation of astigmatism is referred to as with-the-rule (WTR) when the most positive power of the correcting lens is close to horizontal (negative cylinder axes between $0^{\circ}$ and $15^{\circ}$ and between $180^{\circ}$ and $165^{\circ}$ ), against-the-rule (ATR) when the 
most positive power of the correcting lens is close to the vertical meridian (negative cylinder axes $90^{\circ}$ plus and/or minus $15^{\circ}$ ), with other orientations being considered as oblique ${ }^{21}$.

School achievement

School achievement was measured using the "End of Primary School Test", used by $85 \%$ of all Dutch primary schools (the so-called CITO test ${ }^{22}$ ). It provides an objective report on the individual level of school achievement.

The test contains multiple-choice items only and measures intellectual skills in four areas:

1 Language (100 items): spelling, writing, reading comprehension, vocabulary.

2 Mathematics (60 items): understanding figures, mental arithmetic, percentages, fractions, calculations for measures, weights, money, and periods of time.

$3 \quad$ Study skills (40 items): dealing with textbook material and sources of information such as the telephone directory, reading and understanding diagrams, schedules, tables and graphs.

$4 \quad$ World orientation (60 items): applying knowledge acquired in the fields of geography, history, biology, physics, and religious movements.

The individual test results are given as the percentile scores of 'correctly answered items' on the areas language, mathematics, study skills and world orientation, and combined to a total CITO test percentile score. The total test score is used for advising children which type of further education is most suitable for them.

Data analysis

Data were analysed with the Statistical Package for Social Sciences (SPSS) version 10.0. All analyses were carried out separately for children without optical correction and for children who normally wore an optical correction. We analysed the results using right and left eye measurements separately. Also the relation between habitual RE and school achievement for boys and girls was analysed separately. Differences in the average scores on the CITO test between categories of the refractive components, sphere, astigmatism and the orientation of astigmatism were tested by ANOVA, supplemented by post-hoc Bonferroni test. A homogeneity-ofvariance test was performed to analyse whether the ANOVA was allowed.

\section{RESULTS}

\section{Study population}

Nineteen primary schools in the southern part of the Netherlands participated. Of the 588 children aged $11-13$ years visiting these schools, $464(79 \%)$ children were included in the present study. One hundred and twenty-four children were excluded: $37(6 \%)$ because of absence, $29(5 \%)$ because parents did not give permission, 33 $(6 \%)$ because the schools did not use the CITO test, and $25(4 \%)$ children did not wear their optical correction all the time. The total study group $(N=464)$ comprised $239(52 \%)$ girls and $225(48 \%)$ boys; $56(12 \%)$ children did normally wear an optical correction (glasses or contact lenses). The 56 children with optical corrections were measured with their correction (habitual RE). 
Refractive examination

In table 1 the distribution of the spherical and astigmatic part of the habitual RE for right and left eyes is presented. For right eyes the refraction data of children normally not wearing an optical correction showed spherical ametropia in $24 \%$ (13\% myopia, and $11 \%$ hyperopia). For children normally wearing an optical correction the remaining refractive error showed spherical ametropia in 36\% (23\% myopia, and $13 \%$ hyperopia).

The Pearson correlation coefficient for the spherical part of the habitual RE between right and left eyes for all children normally not wearing an optical correction ( $N=408$ ) was $0.72(p<0.01)$. For children normally wearing an optical correction measured with their correction $(N=56)$ the correlation between right and left eyes was $0.69(p<0.01)$.

The distributions of astigmatism for the right and left eyes did not show differences. For the right and left eye of children normally not wearing optical corrections $56 \%$ and $60 \%$ are astigmatic, respectively. Of children normally wearing an optical correction $84 \%$ of right and left eyes are habitual astigmatic.

Table 1 Descriptives of spherioal and astigmatio components of habitual retractive error of all children ( $N=464$ ). Numbers and percentages are given of myopo. emmetropic hyperopic and astigmatio childen for right and lett eves separately. For eyes that are nomally corrected results are presented these corrections (habitual state).

\begin{tabular}{|c|c|c|c|c|}
\hline & \multicolumn{2}{|c|}{ RIGHT EVES $(N=464)$} & \multicolumn{2}{|c|}{ LEFT EYES $(N=464)$} \\
\hline & $\begin{array}{l}\text { Clibder withut } \\
\text { oplind comontion } \\
0.408 \\
201.207\end{array}$ & $\begin{array}{l}\text { Children with } \\
\text { optical correction } \\
\text { 10 } 56 \\
24 \quad 32\end{array}$ & 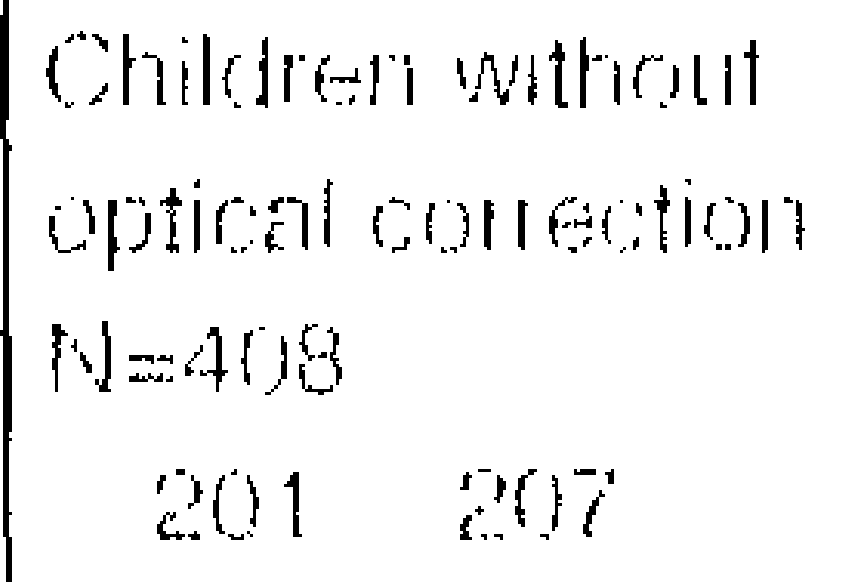 & $\begin{array}{l}\text { Clndren with } \\
\text { optical comention } \\
M=56 \\
24 \quad 32\end{array}$ \\
\hline Myopia & $51(13 \%)$ & $13(23 \%)$ & $48(12 \%)$ & $14(25 \%)$ \\
\hline Emmetropia & $312(76 \%)$ & $36(64 \%)$ & $325(79 \%)$ & $38(68 \%)$ \\
\hline Hyperopia & $45(11 \%)$ & $7(13 \%)$ & $35(9 \%)$ & $4(7 \%)$ \\
\hline No astigmatism & $\begin{array}{l}180(44 \%) \\
\text { क } 85 \% 95\end{array}$ & $\begin{array}{l}9(16 \%) \\
85 q 4\end{array}$ & $\begin{array}{l}165(40 \%) \\
880 \% 85\end{array}$ & $\begin{array}{l}7(13 \%) \\
25 \% 4\end{array}$ \\
\hline Astigmatism & $\begin{array}{l}228(56 \%) \\
8116 \% 112 \\
\end{array}$ & $\begin{array}{l}47(84 \%) \\
819+28\end{array}$ & $\begin{array}{l}243(60 \%) \\
\delta 121+122\end{array}$ & $\begin{array}{l}49(87 \%) \\
\delta 19 \% 28 \\
\end{array}$ \\
\hline $\begin{array}{l}\text { With the rule } \\
\text { Against the rule } \\
\text { Oblique }\end{array}$ & $\begin{array}{l}56(25 \%) \\
82(36 \%) \\
90(39 \%)\end{array}$ & $\begin{array}{l}11(23 \%) \\
11(23 \%) \\
25(54 \%)\end{array}$ & $\begin{array}{l}77(32 \%) \\
53(22 \%) \\
113(46 \%)\end{array}$ & $\begin{array}{l}15(31 \%) \\
13(27 \%) \\
21(42 \%)\end{array}$ \\
\hline
\end{tabular}

School achievements

As shown in table 2, one-way ANOVA showed that boys scored higher than girls on the 'total score' and in three of the four areas: 'mathematics', 'study skills' and 'world orientation'. 
Table 2 Mean total scores and the mean scores on the different areas of the Dutch ClTo test according to gender. One-way ANOVA was conducted to compare the scores on the CITO test between boys and girls (all children. $N=464)$.

\begin{tabular}{|l|c|c|c|}
\hline & \multicolumn{3}{|c|}{ Whole sample group (N=464) } \\
\hline & Group ' & Mean (SD) & $p$-value \\
\hline Language & Boys & $62.3(25.5)$ & 0.92 \\
& Girls & $62.6(25.7)$ & \\
\hline Mathematics & Boys & $65.2(25.8)$ & 0.00 \\
& Girls & $55.0(26.9)$ & \\
\hline Study Skills & Boys & $65.3(24.5)$ & 0.03 \\
& Girls & $60.3(25.9)$ & \\
\hline World orientation & Boys & $66.4(23.2)$ & 0.00 \\
& Girls & $51.9(25.6)$ & \\
\hline Total score & Boys & $64.8(23.8)$ & 0.00 \\
& Girls & $57.3(25.6)$ & \\
\hline
\end{tabular}

1) Boys ( $n=225)$, Girls ( $n=239$ )

\section{PEFRACTIVE ERRORS AND SCHOOL ACHIEVEMENTS}

Spherical refraction and school achievements

As shown in table 3, among children normally not wearing an optical correction, emmetropic children have the highest scores on all areas of the CITO test and hyperopic children the lowest. Among boys, myopes have the highest score and hyperopes have the lowest score on all areas of the CITO test. For girls a different pattern was found: emmetropes have the highest score on all areas of the CITO test and there is no difference between myopes and hyperopes in score.

Tested by ANOVA (table 3 ) it was found that the differences as described above were not statistically significant for the total group and for boys. However, compared to emmetropic girls, ametropic girls show a substantially lower total CITO test score $(10.3, p=0.04)$ and a lower CITO language score $(9.3, p=0.05)$. Although this systematic pattern was seen on the other areas of the CITO test in ametropic girls normally not wearing an optical correction, the differences in CITO test scores were not statistically significant.

ANOVA for children normally wearing an optical correction (measured with their correction) showed no significant difference between the refractive error categories, in any areas of the CITO test score. 
Table 3 ANOVA for the CITO test areas and the habitual spherical refraction of the right eye for all children nomally not wearing an optical correction $(N=408)$. and differentiated to boys and girls $(N=201$ and 207$)$.

\begin{tabular}{|ll|lc|lc|cc|}
\hline & & \multicolumn{2}{|l|}{$\begin{array}{l}\text { All children without } \\
\text { optical correction }\end{array}$} & \multicolumn{2}{l|}{$\begin{array}{l}\text { Boys without } \\
\text { optical correction. }\end{array}$} & \multicolumn{2}{l|}{$\begin{array}{l}\text { Girls without } \\
\text { optical correction }\end{array}$} \\
\hline & Group & Mean (SD) & p-value & Mean (SD) & p-valuf & Meanl(SD) & p-value \\
\hline Language & Myopes & $59.1(24.9)$ & 0.11 & $63.5(21.1)$ & 0.73 & $55.5(27.6)$ & 0.05 \\
& Emmetropes & $63.6(25.7)$ & & $62.4(26.4)$ & & $64.8(25.0)$ & \\
& Hyperopes & $55.9(25.4)$ & & $57.7(28.8)$ & & $54.5(23.0)$ & \\
\hline Mathematics & Myopes & $56.4(28.0)$ & 0.28 & $66.0(25.2)$ & 0.97 & $48.6(28.2)$ & 0.18 \\
& Emmetropes & $60.9(26.9)$ & & $65.1(26.8)$ & & $56.6(26.5)$ & \\
& Hyperopes & $55.3(26.7)$ & & $64.1(22.7)$ & & $48.9(27.9)$ & \\
\hline Study skills & Myopes & $60.5(25.3)$ & 0.37 & $68.9(20.6)$ & 0.68 & $53.7(27.0)$ & 0.14 \\
& Emmetropes & $63.0(25.3)$ & & $64.2(25.1)$ & & $61.8(25.5)$ & \\
& Hyperopes & $57.6(27.3)$ & & $63.3(25.2)$ & & $53.5(28.5)$ & \\
\hline World & Myopes & $56.5(27.3)$ & 0.25 & $70.2(23.9)$ & 0.71 & $45.3(25.0)$ & 0.15 \\
orientation & Emmetropes & $59.8(24.9)$ & & $66.3(22.6)$ & & $53.2(25.4)$ & \\
& Hyperopes & $53.5(29.3)$ & & $64.9(27.9)$ & & $45.2(27.9)$ & \\
\hline Total score & Myopes & $57.3(25.6)$ & 0.11 & $67.4(22.1)$ & 0.77 & $48.9(25.7)$ & 0.04 \\
& Emmetropes & $62.0(24.8)$ & & $64.5(24.3)$ & & $59.3(25.1)$ & \\
& Hyperopes & $54.5(26.3)$ & & $62.0(25.1)$ & & $49.0(26.3)$ & \\
\hline
\end{tabular}

1) myopes $(n=51)$, emmetropes $(n=312)$, hyperopes $(n=45)$

2) myope boys $(n=23)$, emmetrope boys $(n=159)$, hyperope boys $(n=19)$

3) myope girls $(n=28)$, emmetrope girls $(n=153)$, hyperope girls $(n=26)$

Astigmatism and school achievements

As presented in table 4, all astigmatic children not normally wearing an optical correction scored lower on nearly all CITO test areas than their non-astigmatic counterparts. In the total group, children with astigmatism scored significantly lower on the CITO test areas 'language' $(5.3, p=0.04)$, 'study skills' $(5.7, p=0.03)$ and the 'total score' $(5.5 \mathrm{p}=0.03)$. Boys with astigmatism scored significantly lower on the CITO test areas 'study skills' $(7.7, p=0.03)$, and 'world orientation' $(6.9 p=0.04)$. For girls no significant differences were found; although the astigmatic girls score systematically lower than their non-astigmatic counterparts.

Orientation of astigmatism and school achievements The results of the ANOVA revealed no differences between school achievement and the different orientations of astigmatism (WTR, ATR and Oblique). 
ANOVA for the CITO test areas and habitual astigmatism of the right eye for all children nomally not wearing an optical correction $(N=408$. and differentiated to boys and girls $(N=201$ and 207$)$.

\begin{tabular}{|c|c|c|c|c|c|c|c|}
\hline & \multirow[b]{2}{*}{ Group } & \multicolumn{2}{|c|}{$\begin{array}{c}\text { All children } \\
\text { without } \\
\text { optical correction }\end{array}$} & \multicolumn{2}{|c|}{$\begin{array}{c}\text { Boys } \\
\text { without } \\
\text { optical correction }\end{array}$} & \multicolumn{2}{|c|}{$\begin{array}{c}\text { Girls } \\
\text { without } \\
\text { optical correction? }\end{array}$} \\
\hline & & Mean (SD) & p-value & Mean (SD) & pralue & Mean (SO) & p-value \\
\hline Language & $\begin{array}{l}\text { No astigmatism } \\
\text { Astigmatism }\end{array}$ & $\begin{array}{l}65.1(26.7) \\
59.8(24.6)\end{array}$ & 0.04 & $\begin{array}{l}65.0(27.1) \\
59.9(25.0)\end{array}$ & 0.17 & $\begin{array}{l}65.2(26.4) \\
59.7(24.3)\end{array}$ & 0.12 \\
\hline Maths & $\begin{array}{l}\text { No astigmatism } \\
\text { Astigmatism }\end{array}$ & $\begin{array}{l}61.4(26.4) \\
58.4(27.6)\end{array}$ & 0.27 & $\begin{array}{l}65.5(27.3) \\
64.8(25.4)\end{array}$ & 0.86 & $\begin{array}{l}57.9(25.1) \\
51.7(28.3)\end{array}$ & 0.10 \\
\hline Study skills & $\begin{array}{l}\text { No astigmatism } \\
\text { Astigmatism }\end{array}$ & $\begin{array}{l}65.3(25.6) \\
59.6(25.2)\end{array}$ & 0.03 & $\begin{array}{l}69.1(25.4) \\
61.4(23.6)\end{array}$ & 0.03 & $\begin{array}{l}62.0(25.5) \\
57.8(26.7)\end{array}$ & 0.25 \\
\hline $\begin{array}{l}\text { World } \\
\text { orientation }\end{array}$ & $\begin{array}{l}\text { No astigmatism } \\
\text { Astigmatism }\end{array}$ & $\begin{array}{l}61.5(25.6) \\
56.6(25.7)\end{array}$ & 0.06 & $\begin{array}{l}70.6(23.1\rangle \\
63.7(23.0)\end{array}$ & 0.04 & $\begin{array}{l}53.3(25.1) \\
49.2(26.3)\end{array}$ & 0.26 \\
\hline Total score & $\begin{array}{l}\text { No astigmatism } \\
\text { Astigmatism }\end{array}$ & $\begin{array}{l}63.6(25.6) \\
58.1(24.6)\end{array}$ & 0.03 & $\begin{array}{l}68.0(25.7) \\
62.2(22.6)\end{array}$ & 0.09 & $\begin{array}{l}59.8(25.0) \\
53.9(26.0)\end{array}$ & 0.10 \\
\hline
\end{tabular}

1) children without astigmatism $\langle n=180)$, children with astigmatism $(n=228\rangle$

2) boys without astigmatism $(n=85)$, boys with astigmatism ( $n=116)$

3) girls without astigmatism $(n=95)$, girls with astigmatism $(n=112)$

Figure 1 Spherical part of refractive error of children nomally not wearing an optical correction and their school achievemonts (a) all childen. (b) boys, and (c) girls. differentiated to myopia, emmetropia and hyperopia. From left to right the first four bars show the scores of the separate educational chusters; the fifth represents the total score of the Dutch cITO test.

Figure 1 a $\quad N=408$ (myopia: $n=51$, emmetropia: $n=312$; (yperopia: $n=45$ )

All children normally not wearing an optical correction

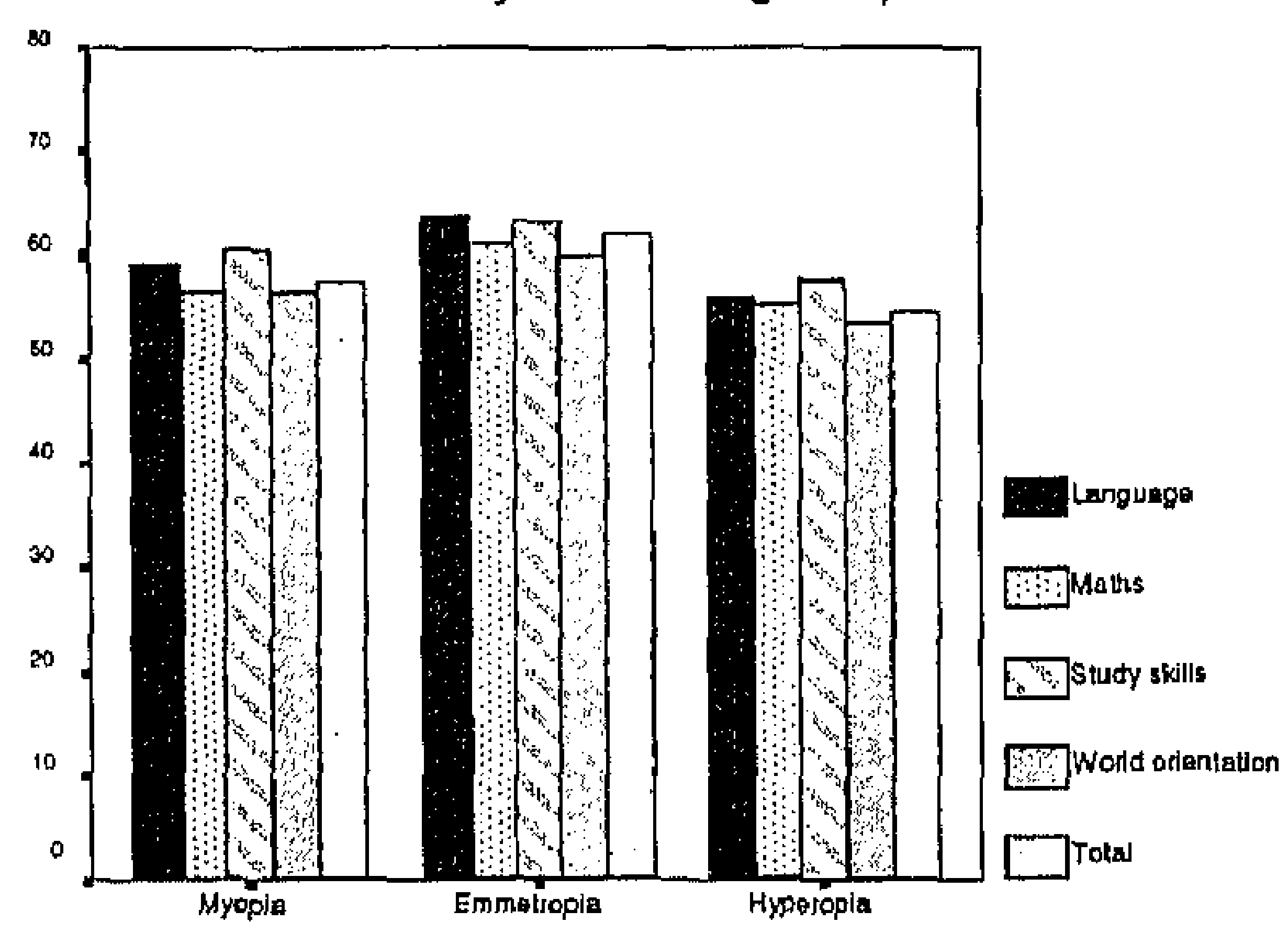

Refraction right

Pve 
Figure th $\quad N=201$ (myopla: $n=23$ : emmetropia: $n=159:$ typeropia: $n=19$ )

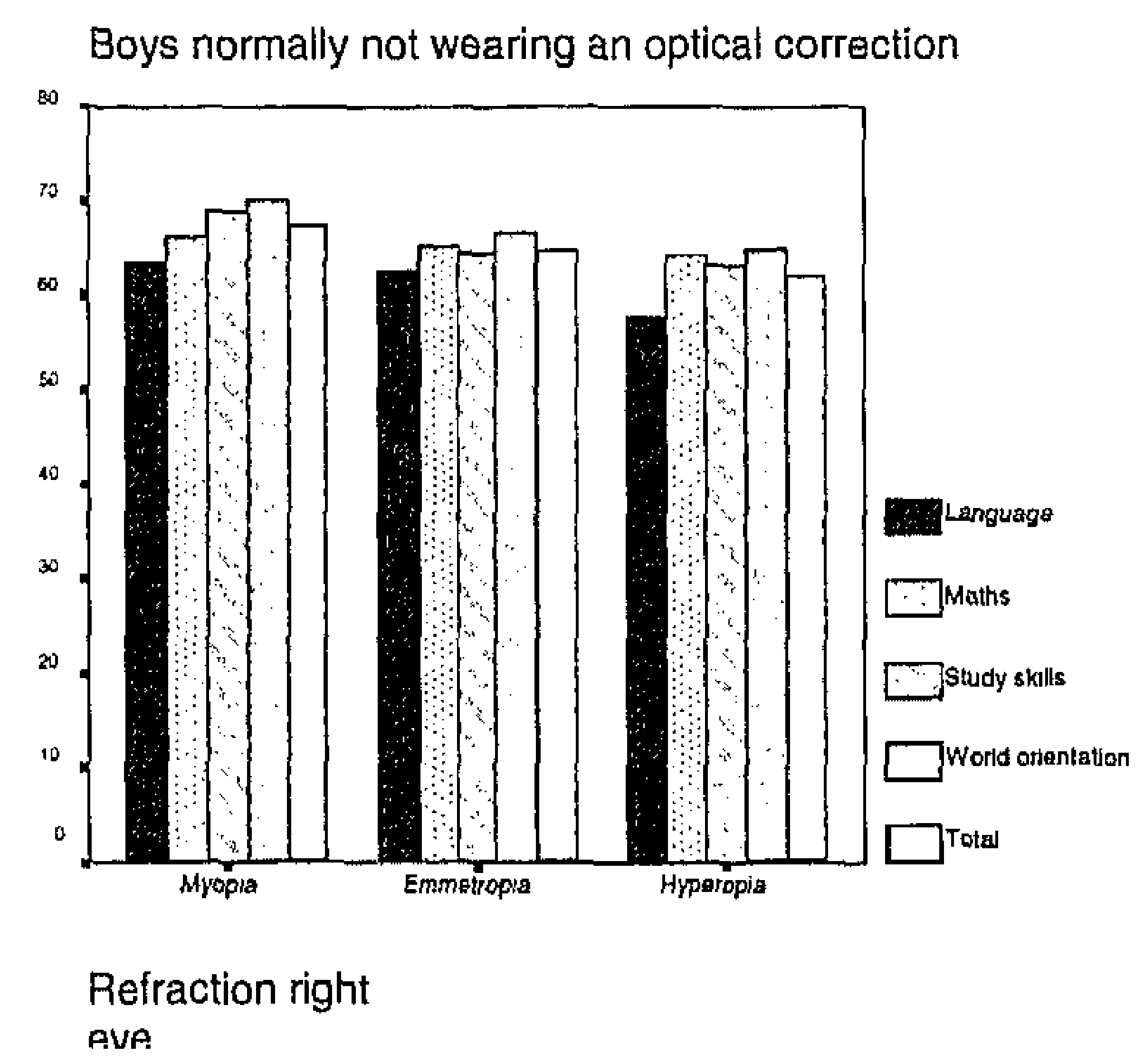

Figure tc $\quad N=207$ (myopia: $n=28$; emmetropia: $n=153$; hyperopia: $n=26$ )

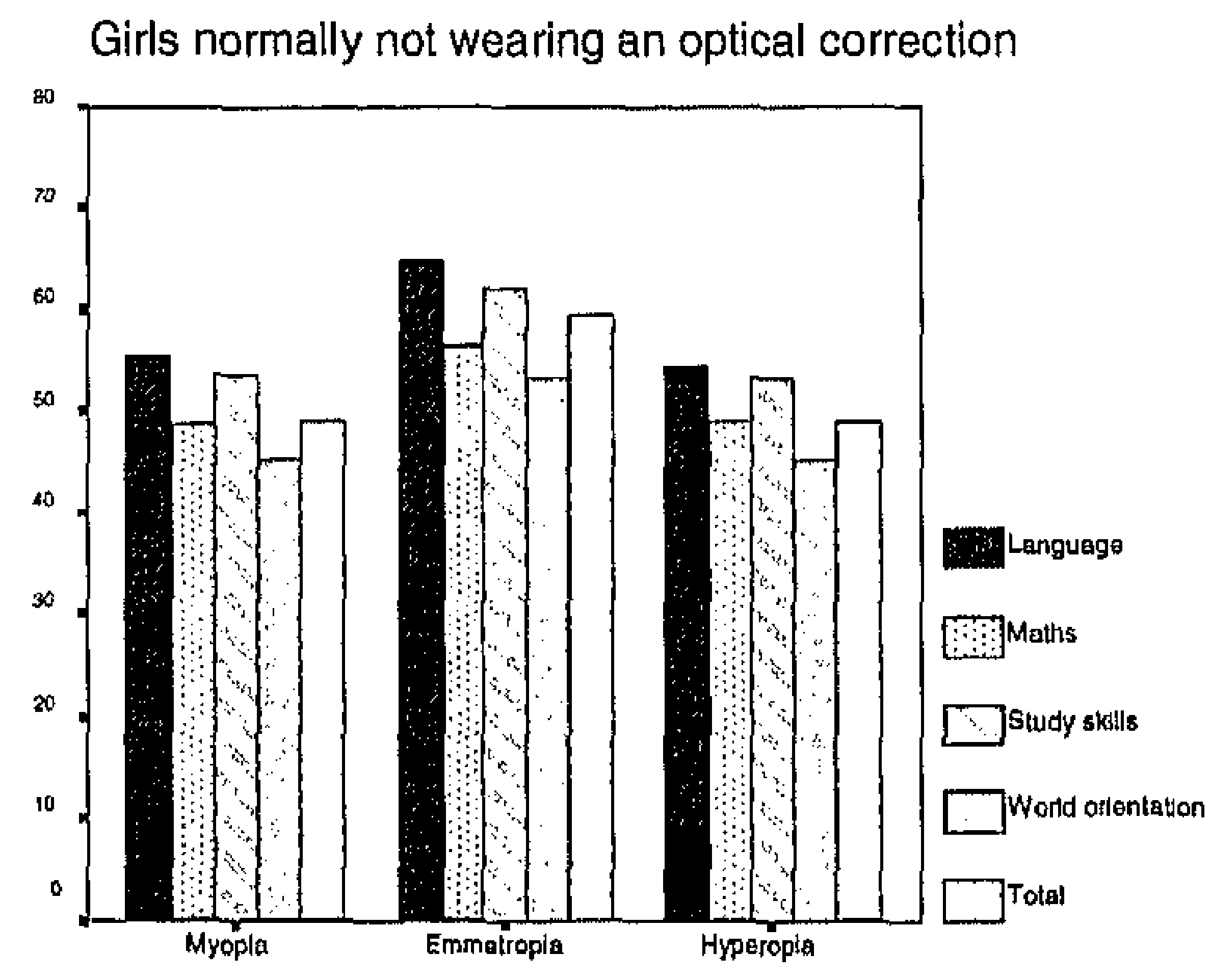

Refraction right

Ava 


\section{DISCUSSION}

In this study we found significant differences for some groups of children between components of refractive error and school achievement. Hyperopic and myopic girls normally not wearing an optical correction scored lower on school achievement (language and total score). Children with uncorrected astigmatism also scored lower (study skills, world orientation, and total score). Given the results we are inclined to advice to define prescription guidelines such that refractive errors will be detected and corrected in order to prevent unnecessary lower school achievements.

Most studies use right eye measurements only, mainly because of high correlations of optometric measurements between both eyes. In our study the Pearson correlation coefficient between the measured refractive errors of the right and left eyes, was also found to be high. However, right and left eyes may play different roles in converting visual information into school tasks and knowledge. Visual information acquired using both eyes may be different from information acquired using one eye only. Also information acquired through right and left cerebral hemispheres may be different. Another reason not to use one eye only might be dominance of one of the eyes. ${ }^{23}$ ANOVA of the relation between refractive errors of left eyes and school achievement did not show any significant results. ANOVA of the relation between refractive errors of right eyes and school achievement showed significant differences. Although some hypotheses are given above we are not able to give detailed explanations for these differences. For scientific reasons it is at least clear that in this type of investigation one should analyse the data for both eyes separately.

Autorefractors give quick and accurate readings of RE, without examiner bias and without the involvement of highly trained clinical personnel ${ }^{24}$. Accommodation reduces the validity and reliability of the instrument ${ }^{25-30}$, because noncycloplegic measurements tend to underestimate the hyperopic status. Because our aim was to evaluate the children under conditions as close as possible to those under which they usually function (habitual RE), the use of a cycloplegium was contra-indicated.

Cycloplegia is a method to detect latent hyperopia or pseudo-myopia, but it does not yield adequate information on habitual $R E$, with this we realize that we measure a different concept than "true" RE.

Generally, with a cross-sectional study, it is not easy to determine the direction of an association. However, with our subject of investigation it is unlikely that lower school achievement causes ametropia or astigmatism. It is therefore reasonable to assume that in the association between ametropia or astigmatism at the one hand and lower school achievement at the other, the first will precede the latter. When considering an etiological interpretation, an unknown causal factor might be responsible for both refractive error and lower school achievement. Mental retardation could, in principle, be such a factor, but in our study population mentally retarded children were not included. Other (hypothetical) common etiological factors related to both refractive error and school achievement were not found in literature. Therefore, in our opinion, it is plausible that the relation we found between ametropia and astigmatism on the one hand, and lower school achievement on the other, has causal significance. 
In contrast to previous studies ${ }^{20,21}$ we found that especially in girls not only hyperopia but also myopia is a risk factor for lower school achievement. We have no explanation for the gender differences found in this study.

Oblique orientation of astigmatism has been indicated as a factor for visual stress. One would expect that such a factor is of importance in school achievement. We could not confirm this hypothesis.

Together with advice of the school teacher, CITO test scores are used to indicate the level of further education for school children. We have found differences in CITO test scores of $10 \%$ for spherical ametropic girls not normally wearing an optical correction and $6 \%$ for astigmatic children not normally wearing an optical correction. In general this degree of difference changes the advice for further education by one school type-level.

We realise that the prevalence of refractive errors varies enormously in different age groups, geographic areas, and in ethnic populations. ${ }^{31-34}$ To repeat the study is desirable, especially to find out whether our findings can be generalised. If our findings could be generalised to especially earlier age groups, it is strongly advisable to detect and correct small RE at an earlier stage. This gives ametropic and astigmatic school children the possibility to diminish their risk for lower school achievement.

A problem here is to define the ideal age for screening on refractive error due to the fact that young children are hyperopic and with age grow towards emmetropia. Screening at too young an age would logically lead to many false positive findings. Refraction screening at the age of roughly 6 years might be feasible.

\section{CONCLUSION}

The relatively high prevalence of refractive errors among school children, and the association between small habitual RE and school achievements, indicates that a lot of children might be at risk for lower school achievement. Ametropic girls without optical corrections showed substantially lower scores on the CITO test than their emmetropic counterparts. In addition, astigmatic children without optical corrections scored considerably lower.

Early refraction screening, in addition to the routine vision screening programme, is worthwhile considering because it might help to identify and overcome possible ophthalmic obstacles in education for children.

Conflict of interest statement

We declare that we have no conflict of interest.

Acknowledgements

The authors thank the schoolchildren who participated in this study. Our gratitude also goes to the former Ambiorix Organisation (nowadays the Ambiorix Organisation 
has merged into the INNOVO foundation, a group of 61 collaborating primary schools in the southern part of the Netherlands), for their help and logistic support in data collection.

Role of the funding source

This study was an academic project involving different disciplines in Maastricht University; there was no external funding source. The corresponding author had full access to all the data in the study and had final responsibility for the decision to submit for publication. 


\section{PEFERENCES}

1 Aine E. Refractive errors in a rural Finnish population. Acta Opthalmol 1984 Dec;62(6); 944-54.

2 Kempen JH, Mitchell $P$, Lee KE, Tielsch JM et al. The prevalence of refractive errors among adults in the United States, Western Europe, and Australia. Arch Opthalmol $2004 \mathrm{Apr} ; 122(4): 495-505$.

3 Midelfart A, Kinge B, Midelfart S, Lydersen S. Prevalence of refractive errors in Norway. Tidsskr Nor Laegeforen 2004 Jan 8;124(1):46-8.

4 Dandona R, Dandona L, Naduvilath TJ, Srinivas M, McCarty CA, Rao GN. Refractive errors in an urban population in Southern India. Invest Ophthalmol Vis Sci.1999 Nov;40(12):2910-8.

5 Mutti DO, Mitchell GL, Moeschberger ML, Jones LA, Zadnik K. Parental myopia, near work, school achievement, and children's refractive error. Investigative Ophthalmology and Visual Science. 2002;43:3633-3640.

6 Pärssinen TO. Relation between refraction, education, occupation, and age among 26and 46-year-old Finns. Am J Optom Physiol Opt 1987;64: 136-143.

7 Grisham JD, Simons HD. Refractive error and the reading process: a literature analysis. J Am Optom Assoc 1986; 57(1): 44-55.

8 Stewart-Brown S, Haslum MN, Butler N. Educational attainment of 10-year-old children with treated and untreated visual defects. Dev Med Child Neurol 1985; 27(4): 504-13.

9 Williams SM, Sanderson GF, Share DL, Silva PA. Refractive error, IQ and reading ability: a longitudinal study from age seven to 11. Dev Med Child Neurol 1988; 30(6): 735-42.

10 Daum KM. Accommodative Insufficiency. Am J Optom Phys Opt 1983; 60: 352-359.

11 Gil-Gouveia R, Martins IP. Headaches associated with refractive errors: myth or reality? Headache 2002;42:256-262.

12 Gawron VJ. Differences among myopes, emmetropes, and hyperopes. Am J Optom Physiol Opt 1981;58:753-760.

13 Grosvenor T. The neglected hyperope. Am J Optom \& Arch Am Acad Optom 1971:376382.

14 Williams WR, Latif AHA, Hannington L, Watkins DR. Hyperopia and educational attainment in a primary school cohort. Archives of Disease in Childhood 2005;90:150153.

15 Rosner J, Rosner J. The relation between moderate hyperopia and academic achievement: how much plus is enough? J Am Optom Assoc 1997 Oct;68(10):648-50.

16 Hirsch MJ. The relationship between refractive state of the eye and intelligence test scores. Am J Optom \& Arch Am Acad Optom 1959;36:12-21.

17 Nadell MC, Hirsch MJ. The relationship between intelligence and the refractive state in a selected high school sample. Am J Optom \& Arch Am Acad Optom 1958;35:321-326.

18 Young FA. Reading measures of intelligence and refractive errors. Am J Optom \& Arch Am Acad Optom 1963;40:257-264.

19 Walton HN, Schubert DG, Clark D, Burke W. Effects of induced hyperopia. Am J Optom Physiol Opt 1978;55:451-455.

20 Grosvenor T. Refractive state, intelligence test scores, and academic ability. Am J Optom \& Arch Am Acad Optom 1970;47:355-361.

21 Teasdale TW, Fuchs J, Goldschmidt E. Degree of myopia in relation to intelligence and educational level. Lancet 1988; 10:1351-54.

22 www.citogroep.nl (go to international page).

23 Pointer JS. Patterns of hand-eye dominance. Br. J. Optom. \& Disp. 1999; 7(3): 88-90.

24 El-Defrawy S, Clarke WN, Belec F, Pham B. Evaluation of a handheld autorefractor in children younger than 6. J Pediatr Ophthalmol Strabismus 1998; 35(2):107-9.

25 Wesemann W, Dick B. Accuracy and accommodation capability of a handheld autorefractor. J Cataract Refract Surg 2000 Jan; 26(1):62-70. 
Harvey EM, Miller JM, Dobson V, Tyszko R, Davis AL. Measurement of refractive error in Native American preschoolers: validity and reproducibility of autorefraction. Optom Vis Sci 2000 Mar; 77(3): 140-9.

27 Young FA, Leary GA, Box RA, Harris E, Baldwin WR, West DC, Johnson C. Comparison of cycloplegic and non-cycloplegic refractions of Eskimos. Am J Optom Arch $m$ Acad Optom 1971 Oct; 48(10):814-25.

28 Hiatt RL, Braswell R, Smith L, Patty JW. Refraction using mydriatic, cyclopleglc, and manifest techniques. Am J Ophthalmol 1973 Nov; 76(5):739-44.

29 Suryakumar $R$, Bobier WR. The manifestation of noncycloplegic refractive state in preschool children is dependent on autorefractor design. Optom Vis Sci 2003 Aug; 80(8):578-586.

30 Pesudovs $\mathrm{K}$, Weisinger HS. A comparison of autorefractor performance. Optom Vis Sci $2004 \mathrm{Jul} ; 81(7): 554-8$. ABSTRACT PUBMED MEDLINE.

31 Lin LL, Shih YF, Hsiao CK, Chen CJ, Lee LA, Hung PT. Epidemiologic study of the prevalence and severity of myopia among schoolchildren in Taiwan in 2000. J Formos Med Assoc 2001; 100(10): 684-91.

32 Villareal MG, Ohlsson J, Abrahamsson M, Sjöström A, Sjöstrand J. Myopisation: The refractive tendency in teenagers. Prevalence of myopia among young teenagers in Sweden. Acta Ophthalmol Scand 2000; 78:177-81.

33 Kuo $A$, Sinatra $R B$, Donahue SP. Distribution of refractive error in healthy infants. J AAPOS 2003; 7(3): 174-77.

34 Junghans BM, Crewther SG. Prevalence of myopia among primary school children in eastern Sydney. Clin Exp Optom 2003; 86(5): 339-45. 


\title{
Chapter 6
}

Habitual spherical refractive error as a risk factor for aspecific health complaints

\author{
Theo J.W. Hendricks ${ }^{1}$ \\ John de Brabander ${ }^{2}$ \\ Frans G. van der Horst ${ }^{1.3}$ \\ Fred Hendrikse ${ }^{2}$ \\ J. André Knottnerus ${ }^{1.3}$
}

Submitted for publication 


\title{
Habital spherical refractive error as a risk factor for aspecific health complaints
}

\author{
ABSTRACT \\ Purpose While uncorrected refractive errors $(R E)$ are held to be related to aspecific \\ health complaints, little research has been done in this field. Therefore we \\ investigated the role of various habitual RE components in relation to aspecific \\ health complaints. \\ Methods \\ Habitual RE of 444 hospital employees were measured (with optical correction if \\ applicable) using an autorefractometer (Topcon, RM-8000B). Health complaints \\ were assessed in a questionnaire (Dutch Questionnaire of Work and Health, \\ $V A G)$. The relation between various habitual $R E$ components and health \\ complaints was analysed by analysis of variance (ANOVA), for both eyes \\ separately.
}

Results Habitual spherical RE of all employees revealed prevalences of $7 \%$ for myopia $>0.50 \mathrm{D}$ and $19 \%$ for hyperopia $>0.50 \mathrm{D}$. Astigmatism $>0.50 \mathrm{D}$ was found in $65 \%$; of these cases, $57 \%$ showed horizontal/vertical orientation and $43 \%$ oblique orientation. Between right and left eyes, and between employees with and without optical correction, no differences were found in the prevalence of the various habitual RE components.

In employees normally wearing an optical correction ( $58 \%$ of all employees), no differences in health complaints were found for the various refractive components. However, in employees normally not wearing an optical correction, higher health complaints scores were found in those with spherical hyperopia and myopia. On a health-scale ranging from 0.00 to 1.00 , emmetropes scored 0.18 whereas myopes and hyperopes scored 0.24 and 0.29 respectively $(p=0.03)$. In relation to health complaints, other RE components investigated did not play a role.

Conclusion Spherical hyperopia and spherical myopia proved to be a risk factor for aspecific health complaints in employees normally not wearing an optical correction. No relation was found between all other investigated optometric components of habitual RE and aspecific health complaints. Since spherical RE can be corrected relatively easy, attention for these errors is advisable.

Key words Ametropia, astigmatism, refractive error, health problems. 


\section{INTRODUCTION}

Uncorrected refractive error (RE) is known to cause visual symptoms of blur, but also more vague symptoms which are grouped under asthenopia, eye strain, and/or headache..$^{1-4}$ According to some authors ${ }^{5-8}$, the clinical manifestations of various RE differ substantially. In contrast to a person with myopia, who has obvious distance visual acuity problems, the person with hyperopia may complain of 'eyestrain' caused by the effort of accommodation. Previous studies have linked moderate hyperopia with discomfort, poor concentration, decreased reading ability and lowered intelligence-test scores. ${ }^{6,9}$ The goals of treatment for hyperopia are improving visual acuity, reducing patient's symptoms, improving binocular function, and preventing amblyopia. ${ }^{7}$ There are several prescribing philosophies about the level of correction of RE. In hyperopia, the opinions of eye care professionals vary about the degree of correction with spectacles or contact lenses, while they are quite consistent about this in myopia. ${ }^{9}$ In myopia some theories describe the idea to under-correct myopia, or to avoid accommodation by using bifocals. However, these theories are aimed at preventing progression rather than optimally correcting myopia in children. Professional literature fails to show consistent guidelines for the level and component of refractive error that warrants a prescription regarding health complaints. Most studies relating RE and non-ophthalmic complaints are limited to the sphere component of $R E .^{3 \cdot 6}$ The objective of the present study is to gain insight into the relation between various optometric components of habitual RE (not limited to the sphere component) and non-ophthalmic-health complaints.

\section{METHODS}

Design and study population

This study has a cross-sectional design. Hospital employees working in the Atrium Medical Centre in Heerlen were asked to participate. This general hospital in the southern part of the Netherlands employs 3000 people. Managers of a number of departments (wards as well as supportive departments like administration, laboratories, $x$-ray) were asked to distribute study information among their employees. A total of 950 people are employed at these departments. Both wards and support departments were included. Employees working outside office hours $(\mathrm{N}=100)$ were not able to participate. Based on information of the personnel department, $6 \%(\mathrm{~N}=51)$ of employees was on sickness leave.

The research followed the tenets of the Declaration of Helsinki, and informed consent was obtained from the employees after explanation of the nature and possible consequences of the study. The Institutional Review Board of the Atrium Medical Centre in Heerlen, the Netherlands, provided the ethical approval for this study.

\section{SURVEY MEASURES}

Measurement of refractive errors

Habitual RE of both eyes separately of hospital employees were measured using an autorefractometer (Topcon, RM-8000B). Auto-refractors give quick and accurate 
readings of $R E$, without examiner bias, and do not require highly trained clinical personnel. ${ }^{9-11}$ Accommodation reduces the validity and reliability of the instrument. ${ }^{10 \text { - }}$

${ }^{12}$ Previous studies on the validity and reliability of non-cycloplegic retinoscopy have measured the latent error (difference in the spherical equivalent refractive error of cycloplegic and non-cycloplegic retinoscopy) in adult populations. ${ }^{13,14}$ These studies show that the latent error increases with the amount of hyperopia manifested during the cycloplegic retinoscopy, indicating that non-cycloplegic retinoscopy tends to underestimate the hyperopic status. When cylinder measures are compared, cycloplegic and non-cycloplegic retinoscopy show no differences in two Jackson crossed cylinders (J180 and J45). This suggests that cycloplegia does not induce any effect on cylinder. ${ }^{15}$ Pesudovs et $a 1^{16}$ reported that the Topcon KR-8000 autorefractometer shows an excellent agreement with subjective refraction. Because our aim was to evaluate the employees under conditions as close as possible to those under which they usually function (habitual RE), the use of a cycloplegium was contra-indicated. Cycloplegia is a method to detect latent hyperopia or pseudo-myopia, but it does not yield adequate information on habitual $R E$; with this we realize that we measure a different concept than "true natural state" RE. Employees normally wearing an optical correction (glasses or contact lenses) were measured with their correction (overrefraction).

We measured spherical and cylindrical habitual RE to the nearest 0.25D. Each eye was measured three times, of which the average was taken. All examinations were carried out with the same instrument by the same observer who did not know the health complaints history of each individual. Right eyes were always tested before left. In most optometric research the degree of RE is defined rather arbitrarily. For optical reasons low degrees of $R E$ are relatively unimportant. In our case low degrees of habitual RE were included since especially these might be of importance in relation to health complaints.

Classification of optometric componenis Using the spherical component (sphere S) of the habitual refraction, the employees were placed in three categories: myopia $<-0.50 \mathrm{D}$, emmetropia [-0.50D to $+0.50 \mathrm{D}]$, and hyperopia $>+0.50 \mathrm{D}$. Astigmatism (cylinder power $\mathrm{C}$ ) was categorised in two groups: employees without astigmatism $\leq 0.50 \mathrm{D}$ and employees with astigmatism $>0.500$. The orientation of astigmatism (axis $\theta$ ) is referred to as with-the-rule (WTR) when the most positive power of the correcting lens is close to horizontal (negative cylinder axes between $0^{\circ}$ and $15^{\circ}$, and between $180^{\circ}$ and $165^{\circ}$ ), against-the-rule (ATR) when the most positive power of the correcting lens is close to the vertical meridian (negative cylinder axes $90^{\circ}$ plus and/or minus $15^{\circ}$ ), with other orientations being considered as oblique. ${ }^{17}$

The components of habitual RE are expressed as sphere $S$, cylinder $C$, axis $\theta$, and analysed for each eye separately.

We also used three often used optometric components: the sphere equivalent of RE (SE), two Jackson crossed cylinders (J180 and J45). ${ }^{17,18} \mathrm{J180}$ represents the cylinder powers set orthogonally at the $90^{\circ}$ and $180^{\circ}$ meridians. $\mathrm{J} 45$ represents the crosscylinder set at $45^{\circ}$ and $135^{\circ}$. 
The conversions are ${ }^{17}: \quad \mathrm{SE}=\mathrm{S}+\mathrm{C} / 2$

$$
\begin{aligned}
& J 180=-(C / 2) \cos (2 \theta) \text {, and } \\
& \mathrm{J} 45=-(C / 2) \sin (2 \theta) .
\end{aligned}
$$

SE was subdivided in three categories: $<-0.50 \mathrm{D},[-0.50 \mathrm{D}$ to $+0.50 \mathrm{D}]$, and $>+0.50 \mathrm{D}$. $J 180$ and $J 45$ were subdivided in two groups:0.00D, and $>0.00 \mathrm{D}$.

Aspecific Health Complaints Questionnaire The questionnaire comprised 13 items (see Table 1) taken from the Dutch Questionnaire of Work and Health (VAG) ${ }^{19,20}$ The health complaints scale comprised dichotomous items (score "0" or "1"), concerning complaints like 'headache', and 'dizziness' and the mean score on all 13 items is used as a measure for health complaints. A higher score means a higher number of complaints. ${ }^{21}$ The results are presented as distributions of averaged scores (minimum score is 0.0 and maximum score is 1.0).

Information on gender, age, and educational level was obtained via additional questions.

Table 1 Hems of quostionnaire on aspecific health complaints and tiredness

\begin{tabular}{|l|c|c|}
\hline Ihems Aspecific Health Complaints and tiredness & Yes & No \\
\hline 1. Are you suffering lately from health complaints? & & \\
\hline 2. Were you regularly disturbed in performing your work due to not feeling well? & & \\
\hline 3. Are you suffering from dizzy spells? & & \\
\hline 4. Do you often forget something? & & \\
\hline 5. Are you regularly suffering from headaches? & & \\
\hline 6. Are you feeling stressed a lot? & & \\
\hline 7. Are you easily irritated? & & \\
\hline 8. Are you often feeling nervous? & & \\
\hline 9. Are you often feeling in a hurry? & & \\
\hline 10. Are you despondent a lot? & & \\
\hline 11. Are you regularly feeling tired just after awakening? & & \\
\hline 12. Are you sleeping badly? & & \\
\hline 13.Are you often in shortage of sleep? & & \\
\hline
\end{tabular}

Data analysis

Statistical analysis was conducted with the Statistical Package for Social Sciences (SPSS for Windows version 10.0). Mean scores were calculated for the health complaints scale. The reliability of the health complaints scale was estimated with Cronbach's alpha. Cronbach's alpha is a measure of internal consistency, based on the average inter-item correlation. The relation between mean score of the health scale and the different optometric components of habitual RE were analysed separately for employees normally with and without optical correction. This was done by a one-way analysis of variance (ANOVA), if the test of homogeneity of variances (Levene's test) showed equal variances, a one-way analysis of variance (ANOVA) was performed. This was supplemented by post hoc multicomparison Bonferroni 
tests if the analysis of variance showed any significant differences in mean scores of a scale. If the test of homogeneity of variances showed unequal variances we used Kruskal-Wallis tests to analyse differences between the scale averages. Chi square analysis was used to determine whether employees normally with and without optical correction differed in their refractive state.

\section{PESULTS}

Study population

Of 799 employees approached, the response was $56 \%(N=444)$. Eight employees $(2 \%)$ were excluded from the analysis because it was not clear whether or not they were normally wearing their optical correction. Of the remaining 436 respondents 171 (39\%) were male; $202(45 \%)$ employees were younger than 40 . The average age was 40.4 years (SD 10.1, range 17 to 60 years). Of the 436 respondents $187(43 \%)$ were normally not wearing an optical correction.

The educational level was low in $12 \%$ (primary school/ lower secondary), middle (higher secondary school) in $46 \%$, and high (bachelor/master) in $42 \%$ of employees. More than $88 \%$ of the participants proved to have finished an educational level of at least upper secondary education, and had a corresponding professional status and income. Therefore we did not analyse SES subgroups separately.

Optometric components of refractive error

The distributions of the various components of habitual RE between right and left eyes did not differ. Therefore in Tables 2 and 3 we only present results for the right eye.

Employees normally not wearing an optical correction (see table 2) proved to have habitual spherical RE in $26 \%$ of the cases (18\% hyperopia and $8 \%$ myopia).

Astigmatism of $>0.50 \mathrm{D}$ was found in $61 \%$ of these employees; the orientation of this astigmatism was WTR in $38 \%$, ATR in $21 \%$ and oblique in $41 \%$. The data for employees normally wearing an optical correction did not differ from those for employees who normally did not.

We did not find differences in prevalence between gender and age subgroups, regarding the various components of habitual $R E$.

\section{Questionnaire}

The 13 items of the questionnaire proved to be internally consistent (Cronbach's alpha=0.77). The mean score was $0.21(S D=0.22)$ for the total study population. The mean scores on this health scale for men and women are $0.19(S D=0.22)$ and 0.23 $(S D=0.21)$ respectively. The mean score for employees younger than 40 years was $0.19(\mathrm{SD}=0.20)$, and for employees aged 40 years or older $0.23(\mathrm{SD}=0.23)$. ANOVA for gender and Kruskal-Wallis analysis for age did not reveal significant differences for age and gender, although women $(p=0.09)$ tended to report higher health complaint scores. 
Table 2 Prevalence of various optometric components of habitual refractive errors for right eyes

\begin{tabular}{|c|c|c|c|}
\hline Category & Range & $\begin{array}{l}\text { Employees } \\
\text { normally not } \\
\text { wearing an optical } \\
\text { correction } \\
N=187(43 \%)\end{array}$ & $\begin{array}{l}\text { Employees } \\
\text { normally } \\
\text { wearing an optical } \\
\text { correction } \\
N=2.49\left(57^{\circ} \%\right)\end{array}$ \\
\hline $\begin{array}{l}\text { Sphere Equivalent } \\
\text { (SE) }\end{array}$ & $\begin{array}{l}<-0.50 D \\
{[-0.50 \mathrm{D} \text { to }+0.50 \mathrm{D}]} \\
>+0.50 \mathrm{D} \\
\text { Mean SE [SD] }\end{array}$ & $\begin{array}{l}31(17 \%) \\
131(70 \%) \\
25(13 \%) \\
-0.06[0.76]\end{array}$ & $\begin{array}{l}36(14 \%) \\
183(74 \%) \\
30(12 \%) \\
-0.05[0.62]\end{array}$ \\
\hline J180 & $\begin{array}{l}\angle 0.00 \mathrm{D} \\
>0.00 \mathrm{D} \\
\text { Mean } \mathrm{J180}[\mathrm{SD}]\end{array}$ & $\begin{array}{l}61(54 \%) \\
53(46 \%) \\
0.00[0.21]\end{array}$ & $\begin{array}{l}92(54 \%) \\
78(46 \%) \\
0.01[0.36]\end{array}$ \\
\hline$\sqrt{45}$ & $\begin{array}{l}<0.000 \\
>0.000 \\
\text { Mean J45 [SD }]\end{array}$ & $\begin{array}{l}42(37 \%) \\
72(63 \%) \\
0.08[0.28]\end{array}$ & $\begin{array}{l}94(55 \%) \\
76(45 \%) \\
-0.02[0.26] \\
\end{array}$ \\
\hline Sphere (S) & $\begin{array}{l}<-0.50 \mathrm{D} \\
{[-0.50 \mathrm{D} \text { to }+0.50 \mathrm{D}]} \\
>+0.50 \mathrm{D} \\
\text { Mean S [SD] }\end{array}$ & $\begin{array}{l}15(8 \%) \\
139(74 \%) \\
33(18 \%) \\
0.13[0.80] \\
\end{array}$ & $\begin{array}{l}16(6 \%) \\
185(75 \%) \\
48(19 \%) \\
\\
0.18[0.63] \\
\end{array}$ \\
\hline Cylinder (C) & $\begin{array}{l}{[0.00 D \text { to } 0.50 D]} \\
>0.500 \\
\text { Mean } C[S D]\end{array}$ & $\begin{array}{l}73(39 \%) \\
114(61 \%) \\
-0.61[0.39]\end{array}$ & $\begin{array}{l}79(32 \%) \\
170(68 \%) \\
\\
-0.67[0.58]\end{array}$ \\
\hline $\begin{array}{l}\text { Orientation of } \\
\text { astigmatism }\end{array}$ & $\begin{array}{l}\text { WTR } \\
\text { ATR } \\
\text { OBL }\end{array}$ & $\begin{array}{l}43(38 \%) \\
24(21 \%) \\
47(41 \%)\end{array}$ & $\begin{array}{l}51(30 \%) \\
45(26 \%) \\
74(44 \%)\end{array}$ \\
\hline
\end{tabular}

Optometric components of refractive errors and health complaints ANOVA was performed to compare the reported health complaints for the various optometric components of habitual RE. This was done separately for employees normally without and with optical correction, and separately for right and left eyes. The results in table 3 show that within the subgroup employees normally not wearing an optical correction, employees with spherical habitual RE (particularly hyperopia) report more health complaints than employees with emmetropia $(p=0.03)$. In relation to health complaints, other optometric components of the habitual refraction did not play a significant role.

Employees normally not wearing an optical correction with spherical ametropia (11\% of all employees) reported substantially more health complaints than their emmetropic counterparts (reported complaints in case of myopia 0.24 , emmetropia 
0.18 , and hyperopia $0.29 ; p=0.03$ ). Post hoc Bonferroni analysis showed that within the employees normally not wearing an optical correction persons with hyperopia report more health complaints than emmetropes (Hyperopia>Emmetropia (.05)).

Contrary to the group employees normally not wearing an optical correction, in the group employees normally wearing an optical correction no significant differences were found in reported health complaints for the analysed optometric components.

Because we used in our research habitual RE as a variable, most of the measured $R E$ was scattered around the emmetropic values. We also looked at differences in mean for other categories $(>0.75 D)$ and found no clues that greater RE give more symptoms.

Table 3 ANOVA for the mean heath complaints in the valious optometric components of habitual etractwe enor (right eye). Employes nomaly not wearing an optical conection and nomally weang an option correction are presented separately

\begin{tabular}{|c|c|c|c|c|c|}
\hline \multirow[b]{3}{*}{ Category } & \multirow[b]{3}{*}{ Range } & \multicolumn{4}{|c|}{ REPORTED HEALTH COMPLAINTS } \\
\hline & & \multicolumn{2}{|c|}{$\begin{array}{l}\text { Employees } \\
\text { normally not } \\
\text { wearing an optical } \\
\text { correction }\end{array}$} & \multicolumn{2}{|c|}{$\begin{array}{l}\text { Employees } \\
\text { nomally } \\
\text { wearing an optical } \\
\text { correction }\end{array}$} \\
\hline & & Mean (SD) & p-value & Mean (SD) & $p$-value \\
\hline $\begin{array}{l}\text { Sphere Equivalent } \\
\text { (SE) }\end{array}$ & $\begin{array}{l}<-0.50 \mathrm{D} \\
{[-0.50 \mathrm{D} \text { to }+0.50 \mathrm{D}]} \\
>+0.50 \mathrm{D}\end{array}$ & $\begin{array}{l}.21(.23) \\
.19(.22) \\
.26(.23)\end{array}$ & 0.41 & $\begin{array}{l}.21(.19) \\
.21(.21) \\
.28(.25)\end{array}$ & 0.18 \\
\hline J180 & $\begin{array}{l}<0.00 \mathrm{D} \\
>0.00 \mathrm{D}\end{array}$ & $\begin{array}{l}.19(.21) \\
.25(.23)\end{array}$ & 0.13 & $\begin{array}{l}.25(.23) \\
.21(.21)\end{array}$ & 0.32 \\
\hline J45 & $\begin{array}{l}<0.00 \mathrm{D} \\
>0.00 \mathrm{D}\end{array}$ & $\begin{array}{l}.19(.18) \\
.23(.24)\end{array}$ & $0.57^{\mathrm{a}}$ & $\begin{array}{l}.23(.21) \\
.23(.23)\end{array}$ & 0.97 \\
\hline Sphere (S) & $\begin{array}{l}<-0.50 \mathrm{D} \\
{[-0.50 \mathrm{D} \text { to }+0.50 \mathrm{D}]} \\
>+0.50 \mathrm{D}\end{array}$ & $\begin{array}{l}.24(.19) \\
.18(.22) \\
.29(.24)\end{array}$ & $0.03^{b}$ & $\begin{array}{l}.23(.22) \\
.21(.21) \\
.26(.23)\end{array}$ & 0.20 \\
\hline Cylinder $(C)$ & $\begin{array}{l}{[0.00 \mathrm{D} \text { to } 0.50 \mathrm{D}]} \\
>0.50 \mathrm{D}\end{array}$ & $\begin{array}{l}.19(.22) \\
.21(.22)\end{array}$ & 0.46 & $\begin{array}{l}.19(.19) \\
.23(.22)\end{array}$ & 0.17 \\
\hline $\begin{array}{l}\text { Orientation of } \\
\text { astigmatism }\end{array}$ & $\begin{array}{l}\text { WTR } \\
\text { ATR } \\
\text { OBL }\end{array}$ & $\begin{array}{l}.21(.20) \\
.26(.25) \\
.20(.22)\end{array}$ & 0.48 & $\begin{array}{l}.21(.22) \\
.23(.24) \\
.25(.21)\end{array}$ & 0.55 \\
\hline
\end{tabular}

a Kruskal-Wallis applied because homogeneity test of variances showed unequal variances.

Bonferroni (p-value) : Hyperopia>Emmetropia (.05) 


\section{DISCUSSION}

In this study the spherical component (S) of habitual RE proved to be a risk factor for reported health complaints in employees normally not wearing an optical correction. No significant relation was found between all other optometric components of habitual RE and health complaints. The spherical component (S) of habitual RE was found in $26 \%$ of employees normally not wearing an optical correction.

Although under-corrected patients with spectacles in our sample scored higher on the aspecific health scale (same pattern as in patients normally not wearing an optical correction), these differences were not statistically significant, probably due to too low numbers.

Traditionally hyperopia is considered a cause of health complaints, since accommodation might arouse visual stress. In our study we indeed found a substantially higher score on health complaints in hyperopia. However, also myopia gives a higher score on health complaints compared to emmetropia. From this finding it can be concluded that accommodation alone cannot entirely explain the relation between ametropia and health complaints.

Generally, with a cross-sectional study, it is not easy to determine the direction of an association. However, with our subject of investigation it is unlikely that health complaints cause ametropia. It is reasonable to assume that in the association between ametropia and health complaints, the first will precede the latter. Nevertheless, when considering an etiological interpretation, an unknown causal factor might be responsible for both RE and health complaints. Diabetes is a wellknown factor related to health complaints and to variations of RE. In our study population age was maximally 60 years; therefore the prevalence of diabetes is low. Thyroid disorders can also be a factor causing both changes in refractive state and health complaints. However, the prevalence of these disorders is extremely low. Accordingly, it is unlikely that these factors would have played a major role in our study. Therefore, in our opinion, although we cannot completely exclude a common cause for ametropia and health complaints as a confounding factor, it is plausible that ametropia contributes to the occurrence of health complaints.

A further question that can be asked is whether selection bias could have been introduced. It is unlikely that employees working on night shift have either more or different refractive errors than the participants. In our opinion it also is unlikely for employees on sickness leave to be less ametropic than the participants. Nonresponders were not followed actively, but as far as reported their non-responding was mainly due to practical or logistic reasons. In conclusion we do not think that selection bias played a significant role.

We realise that the prevalence of refractive errors varies enormously in different geographic areas and in ethnic populations. ${ }^{22-28}$ Although binocular vision and other visual functions (such as contrast sensitivity) could also play an additional role in visual distress, and although these factors are usually classified as secondary to RE, it might be of importance to include these visual functions in further research. To 
repeat the study is desirable, especially to find out whether our findings can be generalised to other groups. If our findings could be generalised, it would be advisable to detect and correct refractive errors to overcome aspecific health problems. This gives people with ametropia the possibility to diminish their risk for health complaints.

\section{CONCLUSION}

Among employees the prevalence of spherical RE $>0.50 \mathrm{D}$ we found was substantial. In employees normally not wearing an optical correction, the spherical component of habitual RE was statistically associated with aspecific health complaints, but only a small amount of the variance of complaints was explained by the habitual RE.

Accordingly, in individuals with aspecific health complaints normally not wearing an optical correction, measurement of spherical RE should be considered.

Conflict of interest statement

We declare that we have no conflict of interest.

Role of the funding source

This study was an academic project involving different disciplines of the Maastricht University; there was no external funding source. The corresponding author had full access to all data in the study and had final responsibility for the decision to submit for publication.

\section{Acknowledgements}

The authors thank the employees who participated in this study. Our gratitude also goes to the Atrium Medical Centre in Heerlen, for their permission to investigate their personnel during office hours and their logistic support in data collection. 


\section{REFERENCES}

1 Anoh-Tanon MJ, Bremond-Gignac D, Wiener-Vacher SR. Vertigo is an underestimated symptom of ocular disorders: dizzy children do not always need MRI. Pediatr Neurol. 2000 Jul;:23(1):49-53.

2 Hendricks TJ, Brabander J de, Horst FG van der, Hendrikse F, Knottnerus JA. Relationship between habitual refractive errors and headache complaints in schoolchildren. Optom Vis Sci. 2007 Feb;84(2):137-43.

3 Weisleder P, Fife TD. Dizziness and headache: a common association in children and adolescents. J Child Neurol. 2001 Oct; 16(10):727-30.

4 Headache Classsification Committee of the International Headache Society. Classification and diagnostic criteria for headache disorders, cranial neuralgias and facial pain. Cephalalgia 1988;8(Suppl 7):29-34.

5 Gawron VJ. Differences among myopes, emmetropes, and hyperopes. Am J Optom Physiol Opt 1981;58(9):753-760.

6 Walton HN, Schubert DG, Clark D, Burke W. Effects of induced hyperopia. Am J Optom Physiol Opt 1978;55(7):451-455.

7 Moore B, Augsburger A, Ciner E, Cockrell D, Fern K. American Optometric Association. Optometric clinical practice guideline: care of the patient with hyperopia. Available at: http://www.aoanet.org/eweb/Documents/CPG-16.pdf. Accessed September 2, 2001.

8 Rosner J. The still neglected hyperope. Optom Vis Sci 2004;81(4):223-224.

9 Lyons SA, Jones LA, Walline JJ, Bartolone AG, Carlson NB, Kattouf V, Harris M, Moore $B$, Mutti DO, Twelker JD. A survey of clinical prescribing philosophies for hyperopia. Optom Vis Sci 2004;81:233-237.

10 el-Defrawy S, Clarke WN, Belec F, Pham B. Evaluation of a hand-held autorefractor in children younger than 6. J Pediatr Ophthalmol Strabismus 1998;35(2):107-9.

11 Wesemann W, Dick B. Accuracy and accommodation capability of a handheld autorefractor. J Cataract Refract Surg 2000;26(1):62-70.

12 Harvey EM, Miller JM, Dobson V, Tyszko R, Davis AL. Measurement of refractive error in Native American preschoolers: validity and reproducibility of autorefraction. Optom Vis Sci 2000;77(3):140-9.

13 Young FA, Leary GA, Box RA, Harris E, Baldwin WR, West DC, Johnson C. Comparison of cycloplegic and non-cycloplegic refractions of Eskimos. Am J Optom Arch Am Acad Optom 1971;48(10):814-25.

14 Hiatt RL, Braswell R, Smith L, Patty JW. Refraction using mydriatic, cycloplegic, and manifest techniques. Am J Ophthalmol 1973;76:739-44.

15 Suryakumar R, Bobier WR. The manifestation of noncycloplegic refractive state in preschool children is dependent on autorefractor design. Optom Vis Sci 2003;80(8):578586.

16 Pesudovs K, Weisinger HS. A comparison of autorefractor performance. Optom Vis Sci 2004;81(7):554-8. ABSTRACT PUBMED MEDLINE.

17 Thibos LN, Wheeler W, Horner D. Power vectors: an application of Fourier analysis to the description of statistical analysis of refractive error. Optom Vis Sci 1997; 74(6): 36775.

18 Atchison D.A.; Comparison of peripheral refractions determined by different instruments, Optom Vis Sci 2003;80(9): 655-660.

19 Konig-Zahn, C., Furer, J.W., \& Tax, B. (1994). Het meten van de gezondheidstoestand. Beschrijving en evaluatie van vragenlijsten. Deel 2: Lichamelijke gezondheid, sociale gezondheid. Assen: Van Gorcum.

20 Schabracq, M. J. W., J.A.M. (1993). Handboek Arbeid en Gezondheid Psychologie. Deel 2: Toepassingen. Utrecht: Lemma.

21 Bentzen N, Bridges-Webb C. An international glossary for general/family practice [editorial]. Fam Pract 1995;12(3):267.

22 Lin LL, Shih YF, Hsiao CK, Chen CJ, Lee LA, Hung PT. Epidemiologic study of the prevalence and severity of myopia among schoolchildren in Taiwan in 2000. J Formos Med Assoc 2001; 100(10): 684-91. 
Villareal MG, Ohlsson J, Abrahamsson M, Sjöström A, Sjöstrand J. Myopisation: The refractive tendency in teenagers. Prevalence of myopia among young teenagers in Sweden. Acta Ophthalmol Scand 2000; 78(2):177-81.

24 Kuo A, Sinatra RB, Donahue SP. Distribution of refractive error in healthy infants. $J$ AAPOS 2003; 7(3): 174-77.

25 Junghans BM, Crewther SG. Prevalence of myopia among primary school children in eastern Sydney. Clin Exp Optom 2003; 86(5): 339-45.

26 Midelfart, A., Kinge B., Midelfart S.\& Lydersen S. Prevalence of refractive errors in young middle-aged adults in Norway. Acta Ophthalmo. Scand. 2002 Oct;80(5): 501 505. Junghans BM, Crewther SG. Prevalence of myopia among primary school children in eastern Sydney. Clin Exp Optom. 2003; 86(5):339-45. Lavery, J.R., Gibson, J.M., Shaw, D.E., \& Rosenthal, A.R. Refraction and refractive errors in an elderly population. Ophthal Physiol. Opt. 1988;8(4):394-396. 


\section{Chapter 7}

Does non-optimal correction of ametropia contribute to health complaints and sickness absence?

Theo J.W. Hendricks ${ }^{1}$

Eefje J.M.P. van Oosterhout ${ }^{1}$

John de Brabander ${ }^{2}$

Frans G. van der Horst ${ }^{1.3}$

Fred Hendrikse?

J. André Knottnerus ${ }^{1.3}$

Submitted for publication

University of Maastricht, Deparmet it of General Practice. The Netherlands

University of Maastricht/ Academic Hospital Maastricht. Department of

Ophthalmology, Eye Research Institute Maastricht (ERIM), the Netherlands

3 Care and Public Health Reseanch Inetitute (CAPHRD). University of Maastricht 


\section{Does non-optimal correction of ametropia contribute to aspecific health complaints and sickness absence?}

ABSIRACT

Purpose Habitual refractive errors (habitual RE) might be related to aspecific health complaints and sickness absence. Because research in this field has not been done so far, we investigated these relations.

Methods Habitual RE of 423 hospital employees was measured using an autorefractometer (Topcon, $\mathrm{RM}-8000 \mathrm{~B}$ ) and related to aspecific health complaints and sickness absence. Health complaints were measured using a questionnaire. Sickness absence was assessed on the basis of organizational absence records. Analysis of variance (ANOVA) and multiple logistic regression analysis were used.

Results A direct relation between habitual RE and sickness absence was not found. On a scale ranging from 0.00 to 1.00 , hyperopes ( $19 \%$ of all employees) reported more aspecific health complaints than emmetropes $(0.23$ versus 0.16 ; $p=.01)$. Hyperopic men ( 0.19 versus $0.12 ; p=.05)$ and hyperopic employees aged 40 years or older $(0.25$ versus $0.15 ; p=.01)$ reported more aspecific health complaints, than their emmetropic counterparts.

Compared to employees with low health complaint scores, employees with high health complaint scores were absent one episode more per two years $(p=.01)$; also their average sickness episode lasted 14 to 23 days longer $(p=.02)$. In total this group showed a higher total sickness absence of 16 to 26 days per year $(p<.01)$.

Conclusion We did not find a direct association between refractive error and sickness absence. The prevalence of habitual RE in employees is relatively high. Spherical component of habitual RE is associated with health complaints. Accordingly, besides measuring visual acuity in screening programs, the measurement of habitual RE is worthwhile considering.

Keywords Aspecific complaints; sickness absence; refractive error; hyperopia; fatigue. 


\section{INTRODUCTION}

Sickness absence is a complex phenomenon since a range of factors, including social factors, organizational factors, work-related factors and individual factors influence its occurrence and course. ${ }^{1}$ The relation between these factors and the occurrence of sickness absence has been investigated in many studies. The health status is an important predictor of sickness absence. ${ }^{1,2}$ One of the factors that might be related to one's health situation, but never has been included in previous studies is non-optimally corrected ametropia of the eyes. Therefore, we investigated whether these so called habitual refractive errors (RE) contribute to health complaints and sickness absence. The clinical appearance of myopia and hyperopia might be totally different. In contrast to a myopic person, who has obvious sight complaints for distance, the hyperopic person may complain of 'eyestrain' caused by the effort of accommodation. Various associated symptoms may have their origin in RE, for instance headaches ${ }^{3}$, dizziness, and occasionally nausea. ${ }^{3-5}$ The hyperopic person might get sight complaints only at an older age, when the eye's accommodation effort is not sufficient anymore..$^{4 \cdot 6}$

The distorted retinal image caused by astigmatism might result in a different clinical appearance. In the present study we explore the relation between habitual RE and health complaints and sickness absence.

\section{METHODS}

Design and research model

The study had a cross sectional design. To investigate the relation between habitual spherical RE, health complaints and sickness absence, we tested a simplified model of the occurrence of sickness absence (see fig.1). In this model the habitual REbound variables (myopia, emmetropia, hyperopia, and astigmatism) and demography-bound variables (age, sex and level of education) are associated with sickness absence following two different pathways:

1 these variables might have a direct relation with sickness absence or

2 these variables are related to health complaints, which in turn are related to sickness absence.

Figure 1 Simplified research model showing a direct (1) and indirect (2 and 3) pathway relating habitual RE and sickness absence.

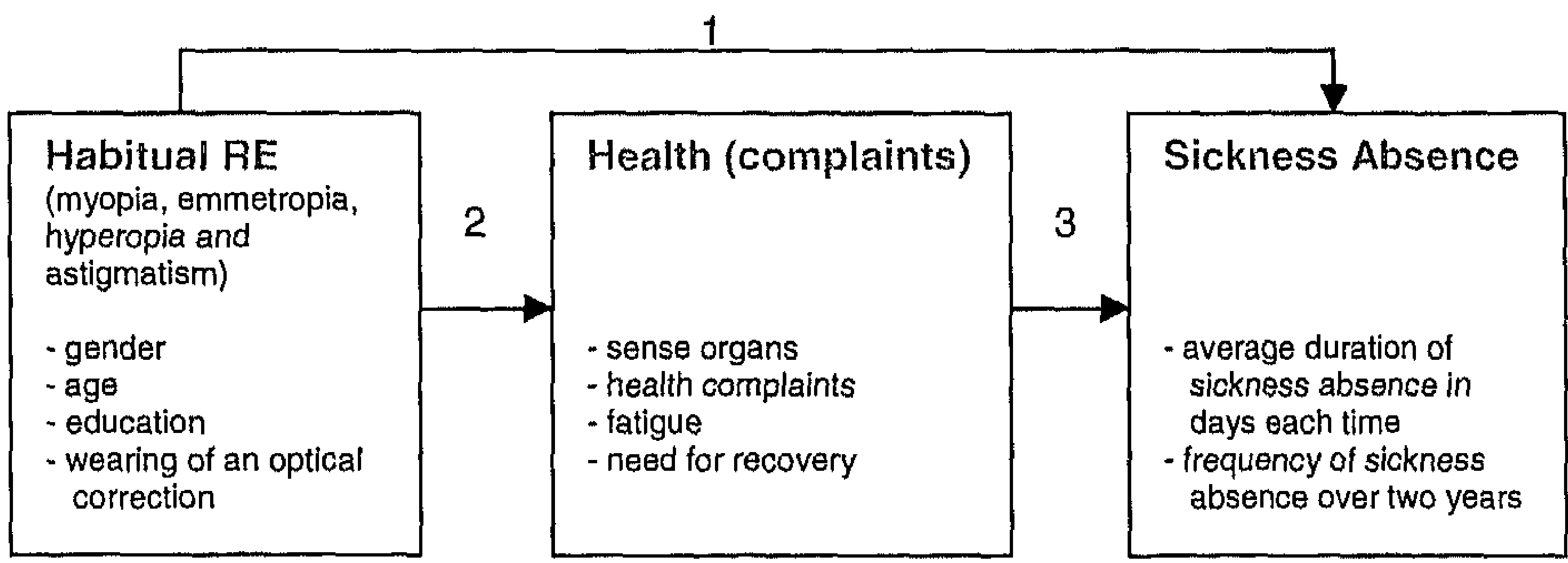


Study population

Subjects for this study were recruited from a population of hospital employees (aged 17 to 60 years). These employees all work in the Atrium Medical Centre in Heerlen, a general hospital in the southern part of the Netherlands where roughly 3000 persons are employed.

During the research period three occupational doctors took care for the total hospital population. Sickness absence did not differ between the populations of the three doctors. Because of financial reasons we had tot restrict ourselves to a research population of around 500 employees. We had to keep account with a non-response of about $50 \%{ }^{7-9}$, the population of one of the three occupational doctors would be sufficient. Managers of the departments involved (wards, administration, laboratories, $\mathrm{x}$-ray) were asked to participate and to distribute study information among their employees. In total 950 persons are employed at the departments under study; of these employees $6 \%(\mathrm{~N}=51)$ were on sickness leave. Employees working outside office hours ( $N=100)$ were not asked to participate. Based on information from the personnel department, The participation in this study comprised a questionnaire concerning health complaints, followed by a measurement of habitual RE with an autorefractometer. Employees who were willing to participate gave written informed consent, which also included permission to collect their sickness absence data of the years 2001 and 2002.

The research followed the tenets of the Declaration of Helsinki. The Ethics

Committee (Institutional Review Board) of the Atrium Medical Centre in Heerlen, the Netherlands, provided the ethical approval for this study.

\section{SURVEY MEASURES}

\section{Sickness absence}

Data on sickness absence were collected from the hospital's organizational absence records between January 2001 and December 2002. In this study sickness absence was defined as the frequency of absence spells in this period as well as the duration of the sickness absence in days. Total sickness absence comprised all sickness absence in days over two years.

Maternity leave and absence due to pregnancy were not included in sickness absence. The first few days a medical documentation is not required, hence sickness is not identical to illness or disease. This definition is used widespread in the Netherlands because employees must also pay their employees during at least the first two years of the so-defined "sickness leave". During the time of survey $6 \%$ is high but it was comparable with the average for hospital and for the Netherlands in general. New legislation caused in recent years lower numbers of this kind of sickness absence. Nowadays the number of sickness absence is roughly $4 \%$.

Optometric examination

RE of both eyes of hospital employees were measured using an autorefractometer (Topcon, RM-8000B). Spherical and cylindrical RE were measured to the nearest $0.25 \mathrm{D}$. Because our aim was to evaluate the employees under conditions as close as possible to those under which they usually function (habitual RE), the use of a cycloplegium was contra-indicated. 
Employees normally wearing an optical correction were measured with their correction. If employees reported to have a distance correction but did normally not wear them (for example they did not wear them the day of examination), they were classified as normally not wearing distance glasses. Employees normally not wearing an optical correction were measured without correction. Each eye was measured three times, of which the average was taken. All examinations were carried out with the same instrument by the same observer who did not know the sickness absence history of each individual.

For optical reasons low degrees of refractive error are relatively unimportant. In our case low degrees of refractive error are included since especially these might be of importance in relation to health complaints and/or sickness absence. Using the spherical part of the refraction, the employees were placed in three categories: myopia <-0.50D, emmetropia [-0.50D to +0.50D], and hyperopia $>+0.50 \mathrm{D}$.

Astigmatism was categorized in two groups: employees without astigmatism $[0.00 D$ to $0.50 \mathrm{D}]$, and with astigmatism $>0.50 \mathrm{D}$.

Health Complaints Ouestionnaire

The health complaints questionnaire consisted of 27 items, divided into four health scales: "hearing and vision complaints", "aspecific health complaints", "fatigue" (Subscales of the Dutch Questionnaire of Work and Health - VAG) ${ }^{10,11}$, and "need for recovery" (Subscale of the Dutch questionnaire on the Perception and Judgment of Work -VBBA). ${ }^{12,13}$ All scales range from 0.00 to 1.00 . The subscale "hearing and vision complaints" includes 3 dichotomous items on sight, eye-complaints and hearing. "Aspecific health complaints" subscale comprises 10 dichotomous items, concerning complaints like 'headache' and 'dizziness'. The fatigue subscale consists of 3 dichotomous items, for instance "Do you often sleep badly?". The scale "need for recovery" consists of 11 dichotomous items on the way people feel when coming home from work, such as "It's difficult for me to relax at the end of a workday". To present the results of reported health complaints the average score on each scale was used. A higher score means a higher number of complaints.

Data analysis

Data were analysed with the Statistical Package for Social Sciences (SPSS) version 10.0. For each single health scale the Cronbach's alpha was measured. Cronbach's alpha is a measure of internal consistency, based on the average inter-item correlation. ${ }^{14}$ The Pearson correlation coefficient was measured between habitual RE of the right and left eye.

\section{ANOVA}

The direct association between habitual RE and sickness absence (relation 1 in figure 1) was tested by ANOVA, supplemented by post hoc Bonferroni tests. A homogeneity-of-variance test was carried out to analyze whether the ANOVA was allowed. When the variances between the groups were not equal, the non-parametric Kruskal-Wallis test $(\mathrm{KW})$ was performed.

Differences in the average scores on the health scales between the habitual RE groups (relation 2 in figure 1) were tested by ANOVA, also supplemented by post hoc Bonferroni tests. 
The relation between the health scales and sickness absence (relation 3 in figure 1) was tested by ANOVA. The scores on the health scales were divided into two categories, representing a logical high and low level of complaints. The used level of significance, for interpretation of the ANOVA results, was .05.

Multiple logistic regression analysis

In order to assess the influence of six independent variables (age, sex, wearing of an optical correction, level of education, sphere and cylinder) simultaneously on sickness leave as dependent variable, we used multiple logistic regression analysis (backward criteria probability-to-remove $\geq 0.10$ ). Odds ratios were calculated to quantify the association between the independent variables and sickness leave. The existence of multicollinearity was investigated. To estimate the proportion of variance in the dependent variable which is explained by the predictor (independent) variables we used R-square.

\section{PESUHES}

Study population

Of 799 employees approached, the response was $56 \%(N=444)$. Eight respondents (2\%) were excluded from the analyses because it was not clear whether or not they were normally wearing their optical correction; $13(3 \%)$ respondents were excluded because they did not complete their questionnaire.

Of the remaining 423 respondents $260(61 \%)$ were female, and $228(54 \%)$ were 40 years or older. The average age was 40.3 years (SD 10.1, range 17 to 60 years). Of the 423 respondents 237 (56\%) were normally wearing an optical correction for distance.

In our study population educational level was low in $12 \%$ (primary school/ lower secondary), middle (higher secondary school) in 46\%, and high (bachelor/master) in $42 \%$ of employees.

\section{Sickness absence}

The average registered frequency of sickness absence was 2.9 times over two years $(S D=3.3)$. The average duration of each sickness absence was 15.4 days $(S D=45.3)$. The average total sickness absence for each employee over 2 years was 44.0 days $(\mathrm{SD}=90.8)$.

Optometric examination

The Pearson correlation coefficient between the habitual RE of the right and left eyes was 0.58 for the sphere component and 0.24 for cylinder component. Based on the right eye, the total sample group consists of $29(7 \%)$ habitual myopes, $315(74 \%)$ habitual emmetropes, and $79(19 \%)$ habitual hyperopes. The mean spherical ametropia of right eyes is $-0.02 \mathrm{D}(\mathrm{SD}=0.80 \mathrm{D})$. A cylinder value $>0.50 \mathrm{D}$ was found for right eyes in $23.6 \%$. Mean cylinder was $0.35 \mathrm{D}$ with $95 \% \mathrm{C.I}$ [0.29D to $0.41 \mathrm{D}]$. In the further analyses we only present right eye results. 
Questionnaire

The internal consistency of the four health scales, using Cronbach's alpha showed: 'hearing and vision complaints' (alpha $=.43$ ), 'health complaints' (alpha $=.77$ ), 'fatigue' (alpha=.66), and 'need for recovery' (alpha=.84).

Because of the low value of alpha in 'hearing and vision complaints', this scale was not used in the further analyses.

Habitual RE and sickness absence (relation 1 in tigure 1)

As presented in table 1, ANOVA in the study population ( $N=423)$ did not reveal differences in average duration of sickness episode, frequency of sickness episodes and the total sickness absence between the three spherical habitual RE groups. Also for gender, age and the cylindrical part of habitual RE subgroups, no differences were found.

Tabte 1 ANOVA for sickness absence tor spherical habitual RE in three measues of sickness absente.

\begin{tabular}{|c|c|c|c|c|c|c|c|c|c|c|}
\hline & & \multicolumn{3}{|c|}{$\begin{array}{l}\text { Average duration } \\
\text { sickness absence } \\
\text { per episode in days }\end{array}$} & \multicolumn{3}{|c|}{$\begin{array}{c}\text { Frequency } \\
\text { sickness absence } \\
\text { per wo years }\end{array}$} & \multicolumn{3}{|c|}{$\begin{array}{l}\text { Total sickness } \\
\text { absence in days } \\
\text { per two years }\end{array}$} \\
\hline & Group & $M$ & $E$ & $H$ & $M$ & $E$ & $H$ & $M$ & $E$ & $\mathrm{H}$ \\
\hline \multirow{2}{*}{$\begin{array}{l}\text { Whole } \\
\text { sample } \\
N=423\end{array}$} & $\begin{array}{c}\text { Mean } \\
(S D)\end{array}$ & $\begin{array}{c}16.2 \\
(47.8)\end{array}$ & $\begin{array}{c}14.7 \\
(44.6)\end{array}$ & $\begin{array}{c}17.9 \\
(47.7)\end{array}$ & $\begin{array}{l}2.3 \\
(2.0)\end{array}$ & $\begin{array}{c}3.0 \\
\text { (3.5) }\end{array}$ & $\begin{array}{c}2.8 \\
(2.7)\end{array}$ & $\begin{array}{c}41.9 \\
(97.2)\end{array}$ & $\begin{array}{c}44.0 \\
(92.8)\end{array}$ & $\begin{array}{c}44.8 \\
(82.1)\end{array}$ \\
\hline & p-value & \multicolumn{3}{|c|}{.86} & \multicolumn{3}{|c|}{.62} & \multicolumn{3}{|c|}{.99} \\
\hline \multirow[t]{2}{*}{$\begin{array}{l}\text { Male }^{2} \\
N=163\end{array}$} & $\begin{array}{c}\text { Mean } \\
\text { (SD) }\end{array}$ & $\begin{array}{c}30.5 \\
(68.0)\end{array}$ & $\begin{array}{c}6.7 \\
(12.8)\end{array}$ & $\begin{array}{c}13.0 \\
(33.0) \\
\end{array}$ & $\begin{array}{l}2.5 \\
(2.3)\end{array}$ & $\begin{array}{c}2.7 \\
(3.2)\end{array}$ & $\begin{array}{c}2.0 \\
(1.8)\end{array}$ & $\begin{array}{c}76.7 \\
(135.2)\end{array}$ & $\begin{array}{c}26.0 \\
(56.0)\end{array}$ & $\begin{array}{c}29.0 \\
(60.7)\end{array}$ \\
\hline & p-value & \multicolumn{3}{|c|}{$K W .70$} & \multicolumn{3}{|c|}{$K W .87$} & \multicolumn{3}{|c|}{$K W .57$} \\
\hline \multirow[t]{2}{*}{$\begin{array}{l}\text { Female }^{3} \\
N=260\end{array}$} & $\begin{array}{c}\text { Mean } \\
\text { (SD) }\end{array}$ & $3.2(3.2)$ & $\begin{array}{c}19.4 \\
(55.0)\end{array}$ & $\begin{array}{c}21.2 \\
(55.6)\end{array}$ & $\begin{array}{c}2.1 \\
(1.8)\end{array}$ & $\begin{array}{c}3.2 \\
(3.6)\end{array}$ & $\begin{array}{c}3.4 \\
(3.0)\end{array}$ & $\begin{array}{c}10.2 \\
(11.6)\end{array}$ & $\begin{array}{c}54.7 \\
(107.6)\end{array}$ & $\begin{array}{c}55.4 \\
(92.9)\end{array}$ \\
\hline & $p$-value & \multicolumn{3}{|c|}{.37} & \multicolumn{3}{|c|}{.50} & \multicolumn{3}{|c|}{.60} \\
\hline \multirow{2}{*}{$\begin{array}{l}\text { Employees } \\
\text { younger } \\
\text { than } 40 \\
\text { years }^{4} \\
N=195\end{array}$} & $\begin{array}{c}\text { Mean } \\
\text { (SD) }\end{array}$ & $7.5(9.9)$ & $\begin{array}{c}12.9 \\
(36.9)\end{array}$ & $\begin{array}{c}5.9 \\
(10.3)\end{array}$ & $\begin{array}{c}3.0 \\
(2.7) \\
\end{array}$ & $\begin{array}{c}2.9 \\
\text { (3.1) }\end{array}$ & $\begin{array}{c}2.9 \\
(2.4)\end{array}$ & $\begin{array}{c}30.0 \\
(40.8)\end{array}$ & $\begin{array}{c}37.4 \\
(90.4)\end{array}$ & $\begin{array}{c}27.5 \\
(59.8)\end{array}$ \\
\hline & $\mathrm{p}$-value & \multicolumn{3}{|c|}{.59} & \multicolumn{3}{|c|}{.99} & \multicolumn{3}{|c|}{.85} \\
\hline \multirow{2}{*}{$\begin{array}{l}\text { Employees } \\
\text { aged } 40 \\
\text { years and } \\
\text { older }^{5} \\
\mathrm{~N}=228\end{array}$} & $\begin{array}{c}\text { Mean } \\
(S D)\end{array}$ & $\begin{array}{c}18.9 \\
(54.6)\end{array}$ & $\begin{array}{c}16.2 \\
(50.4)\end{array}$ & $\begin{array}{c}25.2 \\
(59.0)\end{array}$ & $\begin{array}{c}2.1 \\
(1.8)\end{array}$ & $\begin{array}{c}3.1 \\
(3.8)\end{array}$ & $\begin{array}{l}2.6 \\
(2.2)\end{array}$ & $\begin{array}{c}45.6 \\
(110.0)\end{array}$ & $\begin{array}{c}49.1 \\
(94.9)\end{array}$ & $\begin{array}{c}55.1 \\
(92.4)\end{array}$ \\
\hline & $p$-value & \multicolumn{3}{|c|}{.58} & \multicolumn{3}{|c|}{.39} & \multicolumn{3}{|c|}{.91} \\
\hline
\end{tabular}

1) $M=$ myopes $(n=29), E=$ emmetropes $(n=315), H=$ hyperopes $(n=79)$

2) $M=$ myopes $(n=13), E=$ emmetropes $(n=117), H=$ hyperopes $(n=33)$

3) $M=$ myopes $(n=16), E=$ emmetropes $(n=198), H=$ hyperopes $(n=46)$

4) $M=$ myopes $(n=13), E=$ emmetropes $(n=151), H=$ hyperopes $(n=31)$

$\left.{ }^{5}\right) M=$ myopes $(n=16), E=$ emmetropes $(n=164), H=$ hyperopes $(n=48)$

Refractive errors and health complaints (relation 2 in figure 1)

Table 2 shows that ANOVA in the total study population hyperopes, emmetropes, and myopes score differently on aspecific health complaints. Post hoc Bonferroni 
analysis showed that within the total study population hyperopes report more aspecific health complaints than emmetropes (hyperopes 0.23 and emmetropes $0.16) ;(K W=.04)$.

Compared with their emmetropic counterparts, hyperopic males and employees aged 40 years and older reported more aspecific health complaints $(0.19$ versus 0.12 ; $\mathrm{KW}=.05$, and 0.25 versus $0.15 ; \mathrm{KW}=.02$, respectively).

For the total study sample no significant differences were found for the complaint scales 'fatigue' and 'need for recovery' between the three spherical habitual RE groups. In employees aged 40 years and older, hyperopes reported more 'need for recovery' $(0.30$ versus 0.18$)$ compared to emmetropes.

Apart from the significant differences mentioned, we found in 14 out of 15 analyses a pattern in which emmetropes scored systematically lower than habitual myopes and/or hyperopes.

No differences were found between the two astigmatism subgroups.

Table? ANOVA (A) or Krushal-Walls test (kW) for the health omplaint suales for the total study sample, and sepalately for gender and age subgioups. M=mvopes. E=emmetropes. and H=hyperopes.

\begin{tabular}{|c|c|c|c|c|c|c|c|c|c|c|}
\hline & & \multicolumn{3}{|c|}{$\begin{array}{c}\text { Aspecific health } \\
\text { complaints }\end{array}$} & \multicolumn{3}{|c|}{ Fatigue } & \multicolumn{3}{|c|}{ Need for recovery } \\
\hline & Gouly & $\mathrm{MA}$ & $E$ & $H$ & M & $E$ & $H$ & $M$ & $E$ & $H$ \\
\hline \multirow{2}{*}{$\begin{array}{l}\text { Total study } \\
\text { sample } \\
N=423\end{array}$} & $\begin{array}{c}\text { Mean } \\
(S D)\end{array}$ & $\begin{array}{l}0.22 \\
(.28)\end{array}$ & $\begin{array}{c}.16 \\
(.20)\end{array}$ & $\begin{array}{c}.23 \\
(.24)\end{array}$ & $\begin{array}{c}.29 \\
(.32)\end{array}$ & $\begin{array}{c}.23 \\
(.32)\end{array}$ & $\begin{array}{l}.30 \\
(.37)\end{array}$ & $\begin{array}{c}.27 \\
\{.30)\end{array}$ & $\begin{array}{l}.19 \\
(.23)\end{array}$ & $\begin{array}{l}.25 \\
(.28)\end{array}$ \\
\hline & p-value & \multicolumn{3}{|c|}{$K W .04^{6}$} & \multicolumn{3}{|c|}{.24} & \multicolumn{3}{|c|}{$K W .23$} \\
\hline \multirow{2}{*}{$\begin{array}{l}\text { Male } \\
\text { subgroup }{ }^{2} \\
N=163\end{array}$} & $\begin{array}{c}\text { Mean } \\
\text { (SD) }\end{array}$ & $\begin{array}{l}.25 \\
(.29)\end{array}$ & $\begin{array}{l}.12 \\
(.17)\end{array}$ & $\begin{array}{l}.19 \\
(.21)\end{array}$ & $\begin{array}{l}.36 \\
(.32)\end{array}$ & $\begin{array}{l}.18 \\
(.28)\end{array}$ & $\begin{array}{l}.25 \\
(.37)\end{array}$ & $\begin{array}{l}.29 \\
(.32)\end{array}$ & $\begin{array}{l}.14 \\
(.19)\end{array}$ & $\begin{array}{l}.21 \\
(.26)\end{array}$ \\
\hline & p-value & \multicolumn{3}{|c|}{$K W .05^{7}$} & \multicolumn{3}{|c|}{.09} & \multicolumn{3}{|c|}{$K W .33$} \\
\hline \multirow{2}{*}{$\begin{array}{l}\text { Female } \\
\text { subgroup }^{3} \\
\mathrm{~N}=260\end{array}$} & $\begin{array}{c}\text { Mean } \\
\text { (SD) }\end{array}$ & $\begin{array}{l}.20 \\
(.28)\end{array}$ & $\begin{array}{l}.19 \\
(.21)\end{array}$ & $\begin{array}{l}.25 \\
(.25)\end{array}$ & $\begin{array}{l}.24 \\
(.32)\end{array}$ & $\begin{array}{l}.26 \\
(.33)\end{array}$ & $\begin{array}{l}.33 \\
(.38)\end{array}$ & $\begin{array}{l}.24 \\
(.29)\end{array}$ & $\begin{array}{l}.23 \\
(.25)\end{array}$ & $\begin{array}{l}.28 \\
(.29)\end{array}$ \\
\hline & $p$-value & \multicolumn{3}{|c|}{.20} & \multicolumn{3}{|c|}{.47} & \multicolumn{3}{|c|}{.36} \\
\hline \multirow{2}{*}{$\begin{array}{l}\text { Employees } \\
\text { younger } \\
\text { than } 40 \\
\text { years }{ }^{4} \\
N=195 \\
\end{array}$} & $\begin{array}{c}\text { Mean } \\
\text { (SD) }\end{array}$ & $\begin{array}{r}.31 \\
(.27) \\
\end{array}$ & $\begin{array}{l}.18 \\
(.21)\end{array}$ & $\begin{array}{l}.19 \\
(.18)\end{array}$ & $\begin{array}{l}.36 \\
(.25)\end{array}$ & $\begin{array}{l}.26 \\
(.31)\end{array}$ & $\begin{array}{l}.33 \\
(.35)\end{array}$ & $\begin{array}{c}.36 \\
(.32)\end{array}$ & $\begin{array}{l}.21 \\
(.24)\end{array}$ & $\begin{array}{l}19 \\
(.23)\end{array}$ \\
\hline & $p$-value & \multicolumn{3}{|c|}{.13} & \multicolumn{3}{|c|}{.31} & \multicolumn{3}{|c|}{$K W .24$} \\
\hline \multirow{2}{*}{$\begin{array}{l}\text { Employees } \\
\text { aged } 40 \\
\text { years and } \\
\text { older } \\
N=228\end{array}$} & $\begin{array}{c}\text { Mean } \\
\text { (SD) }\end{array}$ & $\begin{array}{l}.16 \\
(.29)\end{array}$ & $\begin{array}{l}.15 \\
(.19)\end{array}$ & $\begin{array}{l}.25 \\
(.26)\end{array}$ & $\begin{array}{c}.24 \\
(.36)\end{array}$ & $\begin{array}{c}.20 \\
(.31)\end{array}$ & $\begin{array}{c}.27 \\
(.38)\end{array}$ & $\begin{array}{c}.19 \\
(.27)\end{array}$ & $\begin{array}{l}.18 \\
(.23)\end{array}$ & $\begin{array}{l}.30 \\
(.30)\end{array}$ \\
\hline & $p$-value & \multicolumn{3}{|c|}{$K W .02^{B}$} & \multicolumn{3}{|c|}{.51} & \multicolumn{3}{|c|}{$K W .05^{9}$} \\
\hline
\end{tabular}

1) $M(n=29), E(n=315), H(n=79)$

2) $M(n=13), E(n=117), H(n=33)$

3) $M(n=16), E(n=198), H(n=46)$

4) $M(n=13), E(n=151), H(n=31)$

$M(n=16), E(n=164), H(n=48)$
Gonferroni (p-value) : $H>E(.02)$

$7)$ Bonferroni (p-value) : $H>E(.04)$

8) Bonferroni (p-value) : $H>E(.01)$

9) Bonferroni (p-value) : $\mathrm{H}>\mathrm{E}(.02)$ 
Health complaints and sickness absence (relation 3 in figure 1)

Table 3 shows that employees reporting more 'aspecific health complaints', 'fatigue', and 'need for recovery' are absent from their work more often $(K W=.01)$ and for more days ( $\mathrm{KW}=.00$ to $\mathrm{KW}=.02$ ); moreover they have a higher total sickness absence than their colleagues with none or fewer of these complaints $(K W=.00)$.

Table 3 ANOVA or Kruskal-Wallis tests bemeen health scales and sickness absence $(N=423)$.

\begin{tabular}{|c|c|c|c|c|c|c|c|}
\hline & \multirow[b]{2}{*}{ Gonth } & \multicolumn{2}{|c|}{ Average duration } & \multicolumn{2}{|c|}{ Frequency } & \multicolumn{2}{|c|}{ Total } \\
\hline & & $\begin{array}{c}\text { Mentsin! } \\
\text { day }\end{array}$ & 1.valuet & 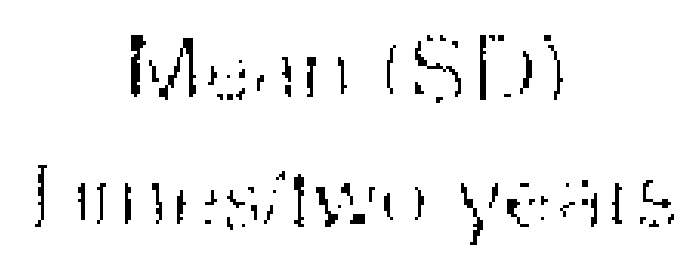 & Writle & 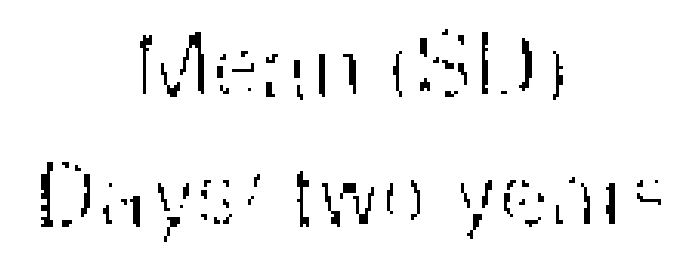 & butwo \\
\hline $\begin{array}{l}\text { Aspecific } \\
\text { health } \\
\text { complaints }\end{array}$ & $\begin{array}{l}\text { A } \\
B\end{array}$ & $\begin{array}{c}8.5(19.8) \\
31.1(75.7)\end{array}$ & $\begin{array}{l}K W \\
<.01\end{array}$ & $\begin{array}{l}2.6(3.2) \\
3.7(3.3)\end{array}$ & .01 & $\begin{array}{l}27.7(59.1) \\
80.6(129.0)\end{array}$ & $\begin{array}{l}\mathrm{KW} \\
<.01\end{array}$ \\
\hline Fatigue & $\begin{array}{l}\text { A } \\
B\end{array}$ & $\begin{array}{l}12.3(33.3) \\
28.1(75.6)\end{array}$ & $\begin{array}{l}K W \\
.02\end{array}$ & $\begin{array}{l}2.7(3.0) \\
3.8(4.0)\end{array}$ & .01 & $\begin{array}{l}35.5(77.5) \\
79.1(126.8)\end{array}$ & $\begin{array}{l}K W \\
<.01\end{array}$ \\
\hline $\begin{array}{l}\text { Need for } \\
\text { recovery }\end{array}$ & $\begin{array}{l}\text { A } \\
B\end{array}$ & $\begin{array}{l}10.9(26.2) \\
24.3(67.9)\end{array}$ & $\begin{array}{l}K W \\
.01\end{array}$ & $\begin{array}{l}2.6(3.2) \\
3.5(3.3)\end{array}$ & .01 & $\begin{array}{l}32.8(69.2) \\
66.2(119.8)\end{array}$ & $\begin{array}{l}K W \\
<.01\end{array}$ \\
\hline
\end{tabular}

1) $A=$ no or few complaints

$B=$ many health complaints

Multiple logistic regression analysis

Multiple logistic regression analysis was used with age, gender, wearing of optical correction, education, and sphere and cylinder components of habitual RE as entered independent variables. Regression coefficients $(\beta)$ calculated to quantify the association between the independent variables and sickness leave as dependent variable did reveal age $(\beta=0.02[0.00,0.04] ; p=.02)$, education $(\beta=-0.18[-0.33,-0.03]$; $p=.02)$, and wearing of an optical correction $(\beta=0.36[-0.02,0.74] ; p=.06)$ as significant variables. The $\beta$ for age shows 0.02 more sickness absence for each year of age. For education $\beta=-0.18$, indicating that higher education (classified into three levels: low, middle, and high) is protective with respect to sickness absence. And the regression coefficient for wearing of an optical correction indicates that employees normally wearing an optical correction scored higher on sickness absence.

The reduced model for the relationship between the dependent and the independent variables together predict $6 \%$ of total variance ( $R$ square of reduced model for the relationship between these independent variables and sickness leave is 0.06 ) Gender and habitual RE components (sphere and cylinder) did not show relations with sickness leave. 


\section{DISCUSSION}

In 4 out of 15 analyses habitual hyperopes reported statistically significantly more aspecific health complaints than emmetropes. The remaining 11 analyses did not show statistically significant differences between the three refractive groups (hyperopia, emmetropia, and myopia). Nevertheless in 10 of these analyses we found a systematically higher score for habitual myopes and/or hyperopes compared to emmetropes. Given these results we can conclude that non-optimally corrected ametropia (hyperopia and myopia) is associated to health complaints.

Although all health complaints involved proved to be related to sickness absence, we could not confirm a direct relation between habitual RE and sickness absence.

Most studies use right eye measurements only, mainly because of high correlations between both eyes in natural state. In our study the Pearson correlation coefficient between the outcomes of the measurements of habitual RE between right and left eyes was found to be relatively low (0.58). This low correlation between the residual refractive errors in the two eyes is attributable also to the reduced range of refractive errors that are measured when the subjects wear correction, and to a large amount of anisometropia (difference of refractive error between right and left eyes) in the study population. The origin of the large amount of anisometropia is unknown. On theoretical grounds dominance of right or left eyes might play different roles in originating health complaints. We therefore investigated right and left eye information separately and found comparable results. In relation to aspecific health complaints we could not confirm a need to analyse the data for both eyes separately.

Auto-refractors give quick and accurate readings of refractive error, without examiner bias and without the need for highly trained clinical personnel. ${ }^{15}$ It is known that accommodation reduces the validity and reliability of the instrument. ${ }^{16,17}$ Previous studies on the validity and reliability of non-cycloplegic measurements in adult populations indicate that non-cycloplegic measurements tend to underestimate the hyperopic status. ${ }^{18-20}$ Because our aim was to evaluate the employees under conditions as close as possible to those under which they usually function (habitual $\mathrm{RE}$ ), the use of a cycloplegium was contra-indicated. Cycloplegia is a method to detect latent hyperopia or pseudo-myopia, but it does not yield adequate information on habitual RE, with this we realize that we measure a different concept than absolute RE.

Social economic status based on level of education has been found to be related to health. ${ }^{21-22}$ In our study lower levels of education were also associated with more sickness absence.

Generally, with a cross-sectional study, it is not easy to determine the direction of an association. However, with our subject of investigation it is unlikely that aspecific health complaints cause ametropia. It is reasonable to assume that in the association between habitual $R E$ and these health complaints, the first will precede the latter. When considering an etiological interpretation, an unknown causal factor might be responsible for both habitual $R E$ and health complaints. Diabetes is a well-known 
factor related to refractive errors and health complaints. In our study population age was limited to 60 years; therefore the prevalence of diabetes is relatively low (less than $1 \%) .^{23}$ Thyroid disorders, muscle dystrophy and other systemic disorders can also be factors causing both changes in refractive state and health complaints. However, the prevalence of these disorders is extremely low and therefore it is unlikely that these factors would have played a major role in our study in a healthy workers population. Therefore, in our opinion, it is plausible that small habitual RE is an etiological determinant of aspecific health complaints.

A further question is whether selection bias could have been introduced. The population approached did not differ on sickness absence from the non-approached population. Because the non-response was not higher than in comparable research ${ }^{7-}$ ${ }^{9}$ non-responders were not followed actively. In our opinion it is likely that employees on sickness leave have more ametropia than the participants. Among the participants the explained variance in health complaints by ametropia was low; we therefore do not think that selection bias played a significant role.

In accordance with literature ${ }^{4,5,24}$ in our study habitual hyperopes report more aspecific health complaints than emmetropes. So far nearly all ophthalmic screening programs are restricted to visual acuity tests only and do not take into account refractive errors (hyperopia and myopia).

Future studies could be directed at the different roles of right and left eyes in relation to aspecific health complaints. Eye dominance and visual acuity could also be taken into account. To exclude selection bias completely, a prospective research design would be useful.

\section{CONCLUSION}

The prevalence of habitual RE in employees is relatively high ( $7 \%$ myopia and $19 \%$ hyperopia). We found that spherical component of habitual RE is associated with health complaints. Probably this association is causal in that habitual RE leads to aspecific health complaints. A direct relation between habitual RE and sickness absence could not be confirmed. From a perspective of well-being, attention for habitual RE is worthwhile, especially because these errors can easily be corrected.

Conflict of interest statement

We declare that we have no conflict of interest.

Acknowledgements

The authors thank the employees who participated in this study. Our gratitude also goes to the Atrium Medical Centre in Heerlen, for their permission to investigate their personnel during office hours and their logistic support in data collection 


\section{REFERENCES}

1 Janssen N, Kant IJ, Swaen GM, Janssen PP, Schroer CA. Fatigue as a predictor of sickness absence: results from the Maastricht cohort study on fatigue at work. Occup Environ Med 2003; 60:71-76.

2 Schaufeli W, Bakker A, De Jonge J. (2003). De psychologie van Arbeid en Gezondheid. Houten: Bohn Stafleu Van Loghum.

3 Hendricks TJ, Brabander de J, Horst van der FG, Hendrikse F, Knottnerus JA. Relationship between habitual refractive errors and headache complaints in schoolchildren. Optom Vis Sci. 2007Feb;84(2):137-143.

$4 \quad$ Vaughan D, Asbury T. (1977). General Ophtalmology (8th ed.): Lange Medical Publication.

$5 \quad$ Kanski JJ. (2003). Clinical Ophthalmology. A systematic approach (5 $5^{\text {th }}$ ed.): ButterworthHeineman Ltd ISBN 0750655410.

$6 \quad$ Gawron VJ. Differences among myopes, emmetropes, and hyperopes. Am J Optom Physiol Opt 1981;58:753-760.

7 Houkes, I, Janssen, PPM, De Jonge, J, \& Nijhuis, FJN. (2001). Specific relationships between work characteristics and intrinsic work motivation, burnout and turnover intention: A multi-sample analysis. European Journal of Work and Organizational Psychology, 10,1-23.

8 Kessler, R.C., \& Greenberg, D.F. (1981). Linear panel analysis. Models of quantitative change. New York: Academic Press.

9 Verbeek, MJCM. (1991). The design of panel surveys and the treatment of missing observations. PhD thesis, Nijmegen, The Netherlands: NWO.

10 Konig-Zahn C, Furer JW, Tax B. (1994). Het meten van de gezondheidstoestand. Beschrijving en evaluatie van vragenlijsten. Deel 2: Lichamelijke gezondheid, sociale gezondheid. Assen: Van Gorcum.

11 Schabracq MJW (1993). Handboek Arbeid en Gezondheid Psychologie. Deel 2: Toepassingen. Utrecht: Lemma.

12 Ouwerkerk RJ, Meijman TF, Mulder G. (1994). Arbeidspsychologische taakanalyse. Utrecht: Lemma.

13 Veldhoven M van., Meijman TF, Broersen JPJ, Fortuin RJ, (1997). Handleiding VBBA. Onderzoek naar de beleving van psychosociale arbeidsbelasting en werkstress met behulp van de Vragenlijst Beleving en Beoordeling van de Arbeid. Amsterdam: SKB.

14 Pallant. (2001). SPSS manual guide.

15 el-Defrawy S, Clarke WN, Belec F, Pham B. Evaluation of a handheld autorefractor in children younger than 6. J Pediatr Ophthalmol Strabismus 1998;35:107-9.

16 Wesemann W, Dick B. Accuracy and accommodation capability of a handheld autorefractor. J Cataract Refract Surg 2000;26(1):62-70.

17 Harvey EM, Miller JM, Dobson V, Tyszko R, Davis AL. Measurement of refractive error in Native American preschoolers: validity and reproducibility of autorefraction. Optom Vis Sci 2000;77(3):140-9.

18 Young FA, Leary GA, Box RA, Harris E, Baldwin WR, West DC, Johnson C. Comparison of cycloplegic and non-cycloplegic refractions of Eskimos. Am J Optom Arch Am Acad Optom 1971;48(10):814-25.

19 Hiatt RL, Braswell R, Smith L, Patty JW. Refraction using mydriatic, cycloplegic, and manifest techniques. Am J Ophthalmol 1973;76:739-44.

20 Pesudovs $\mathrm{K}$, Weisinger HS. A comparison of autorefractor performance. Optom Vis Sci, 2004;81(7), 554-558.

21 Wilkinson RG. Class and health, research and longitudinal data. London: Tavistock Publications 1986.

22 Davey Smith G, Blane D, Bartley M. Explanations for socio-economic differentials in mortality. Eur J Public Hlth 1994;4:132-44.

23 Baan C.A., Poos M.J.J.C. (RIVM), see: www.nationaalkompas.nl : diabetes mellitus: omvang van het probleem

24 Rosner J. The still neglected hyperope. Optom Vis Sci 2004;81(4):223-224. 


\section{Chapter 8}

Using plus-lenses next to visual acuity as a low-tech measurement method to improve the detection of refractive errors in ambulatory settings

Theo J.W. Hendricks ${ }^{1}$

John de Brabander?

Frans $G$. van der Horst ${ }^{1,3}$

Fred Hendrikse ${ }^{2}$

J. André Knottnerus ${ }^{1.3}$

Submitted for publication

University of Maastricht. Depaltment of General Practice. the Nethertands

University of Marstricht Academic Hospital Maastricht, Department of

Ophthalmology. Eye Research Institute Maastricht (ERIM), the Netherlands

Care and Public Healih Research Institute (CAPHRl), University of Maastricht 


\section{Using plus-lenses next to visual acuity as a low-tech measurement method to improve the detection of refractive errors in ambulatory settings}

\section{ABSTRACT}

Purpose Refractive error (RE) has been indicated one of the risk factors for aspecific health complaints and functional problems. For health care workers in ambulatory settings a reliable and feasible method to detect RE is necessary. We investigated the additional diagnostic value of using plus-lenses next to visual acuity (VA) measurement in order to detect RE in ambulatory settings

Methods In a cross-sectional study REs of 520 children, aged $11-13$ years, were measured using an autorefractometer (Topcon, RM-8000B). Autorefractive measurements were used to categorize ametropia. Using an ETDRS chart, VA was measured without and with spherical plus-lenses (S+0.50D and $S+1.00 \mathrm{D}$ ). Sensitivity and specificity for detecting RE by VA-measurements without and with use of the plus-lenses were used to plot ROC curves, using autorefractor measurements as the reference standard.

Findings No differences were found in the prevalence of the various components of RE between right and left eyes. RE measurements revealed $74 \%$ emmetropia $[+0.50 \mathrm{D},-0.50 \mathrm{D}], 14 \%$ myopia $<-0.50 \mathrm{D}$, and $12 \%$ hyperopia $>+0.50 \mathrm{D}$. Astigmatism $>0.50 \mathrm{D}$ was present in $33 \%$ of the children.

ROC curves for VA-measurements alone showed an Area Under the Curve (AUC) for myopia of 0.71 (Confidence Interval 0.66-0.77); for hyperopia 0.57 (0.49-0.64), and for astigmatism 0.63 (0.58-0.68)

VA-measurement with use of plus-lenses (0.50D) showed for myopia an AUC of $0.42(0.37-0.48)$, for hyperopia $0.72(0.65-0.78)$, and for astigmatism $0.55(0.50-$ $0.60)$. Both used plus-lenses showed equal results in this respect.

Based on ROC curves optimal sensitivity/specificity profiles were reached for myopia using VA-measurements only (63\%/78\%; odds ratio 6.0$)$, for hyperopia using VA-measurements in combination with plus-lenses $(67 \% / 75 \%$; odds ratio $6.1)$ and for astigmatism using VA-measurements only $(58 \% / 73 \%$; odds ratio 3.0).

Conclusion In ambulatory settings, simple VA-measurement is a reasonably valid low-tech method to detect myopia, but not for hyperopia and astigmatism. The use of plus-lenses next to VA-measurement is of significant importance in detecting hyperopia.

Key words Refractive error, screening, visual acuity, general practice. 


\section{INTRODUCTION}

The increasing prevalence of refractive error (RE) in children and young adults and its implications on diminished VA and eye development are recognised as a worldwide problem by the WHO. ${ }^{1}$ The high prevalence and implications of these errors and the costs of refractive correction (measurement of RE, production of glasses or contact lenses) make these conditions a substantial public health and economic problem.

In the ideal situation the unaccommodated eye will focus parallel rays of light as received from a distant light source into a sharp image upon the fovea. This condition is called emmetropia. Variations from the emmetropic state are collectively referred to as ametropia. The two basic forms of ametropia are hyperopia and myopia. In myopia parallel rays of light focus in front of the fovea, causing blurred distance vision at all ages. Hyperopia is the condition in which parallel rays of light after entering the unaccommodated eye focus behind the retina, causing blurred vision. Astigmatism refers to the condition in which there is not one focal point, but the eye has different optical powers at two meridians ninety degrees apart.

The clinical appearance of myopia and hyperopia might be totally different. In contrast to a myopic person, who has obvious sight complaints for distance, the hyperopic person may complain of 'eyestrain' caused by the effort of accommodation. Various aspecific health complaints may have their origin in $R E$, for instance headaches ${ }^{2-4}$ dizziness ${ }^{5,6}$, and occasionally nausea ${ }^{5,6}$. The hyperopic person might get sight complaints only at an older age, when the eye's accommodation effort is not sufficient anymore. The clinical appearance of astigmatism is different because of the the distorted and sometimes doubled retinal image.

Aspecific health complaints are complex phenomena, influenced by many factors. Because of the substantial prevalence of these complaints encountered in primary care, it would be highly inefficient to refer every such patient to an optometrist or ophthalmologist to exclude RE.

$R E$, especially myopia, is a common cause of visual impairment. Visual acuity (VA) measurement in children is important because some children may not complain of blurred vision. Refractive errors causing diminished VA in such children may remain undiagnosed for a period of time in the absence of VA-screening. ${ }^{7}$ Early detection of diminished VA allows in such patients timely interventions in the form of spectacle correction.

Low degrees of myopia and astigmatism are not necessarily related to awkwardly diminished VA. Mild to moderate hyperopia can be overcome by accommodation in youth and early adulthood, with the result that low degrees of hyperopia often are not noticed. ${ }^{5-9}$ However, there is substantial evidence that hyperopia is a cause of amblyopia. ${ }^{5-9}$ Hence, not all refractive errors will be detected using VA-tests only. If VA-screening in a patient yields a good visual acuity this does not exclude the existence of refractive error. 
Measurement of RE with an autorefractometer is not a standard procedure (too expensive) in ambulatory settings. To improve decision making on referral from ambulatory settings (e.g., primary care and public health) to ophthalmologists or optometrists, a valid, efficient and feasible low-tech method to detect refractive errors in these settings would be of use. Diagnostic refractionizing is suggested by Baggen as a valid instrument to detect RE. In this method the influence of $S+0.50 \mathrm{D}$ and $\mathrm{S}$ $0.50 \mathrm{D}$ on VA is used to determine whether a patient is hyperopic or myopic. The use of the minus lens to detect myopia is straightforward, because correction of myopia with minus-lenses immediately improves VA. The additional role of using a positive lens in detecting RE is more difficult, because patients with hyperopia are very often able to correct their hyperopia using accommodation. Correcting hyperopia with pluslenses does not necessarily improve their VA.

The objective of this study was to determine the diagnostic value of VA measurement as an instrument to detect RE in ambulatory settings. We also investigated the additional value of two different plus-lenses $(S+0.50 \mathrm{D}$ and $S+1.00 \mathrm{D})$ in the detection of $R E$, as the question is raised whether a lower $(S+0.50 D)$ or a higher $(S+1.00 D)$ plus-lens should be used in the diagnostic process.

\section{METHODS}

Design and study population

The present study has a cross-sectional design. Twenty-one primary schools in the southern part of the Netherlands were approached. The children in their last year of primary school (aged between 11 and 13 years) participated in this study. The teachers of the schools distributed the study information to the children and their parents. The research followed the tenets of the Declaration of Helsinki, and informed consent was obtained from the parents after explanation of the nature and possible consequences of the study. Participation in this study comprised a measurement of $\mathrm{RE}$ of the eyes of the children with an autorefractometer as a reference standard and the measurement of visual acuity (VA) with and without the use of two plus-lenses $(S+0.50 \mathrm{D}$ and $S+1.00 \mathrm{D})$. In order to facilitate participation the measurements took place during school time.

\section{SURVEY MEASURES}

\section{Refractive errors}

REs of both eyes of the children were measured using an autorefractometer (Topcon RM-8000B). Spherical and astigmatic deviations were measured to the nearest $0.25 \mathrm{D}$. Astigmatic axes were measured to the nearest five degrees, negative cylinders being used for all measurements. Children normally wearing an optical correction were measured with their correction. Each eye was measured three times, of which the average was taken. Right eyes were always measured before left eyes. Using the spherical part of the refraction, the children were placed in three categories: myopia <-0.50D, emmetropia [ $-0.50 \mathrm{D}$ to $+0.50 \mathrm{D}]$, and hyperopia $>+0.50 \mathrm{D}$. Astigmatism was categorised in two groups: children without astigmatism $\leq 0.50 \mathrm{D}$ and children with astigmatism $>0.50 \mathrm{D}$. 
Visual acuity (VA)

In ambulatory settings a letter acuity chart, such as the Snellen chart, is commonly used. Variation in the number of letters on each line presents the subject with a task of increasing difficulty rather than providing an equivalent task at all acuity levels. Perhaps the most important problems with the design of the Snellen chart are the irregular progression of the size of the letters on the chart and the lack of an accurate or standardized scoring system. These problems ${ }^{8 \cdot 10}$ have led to the development of alternatives to the Snellen chart. The most notable innovations are the use of a geometric progression in the size of the letters (that is, the change between lines occurs in uniform steps) and the introduction of an equivalent task for all acuity levels, ensuring that the only variable is the change in the angular size of the letters. This is achieved by using a set of letters that are equally legible and by presenting the same number of letters on each line of the chart. These charts, originally developed for the early treatment of diabetic retinopathy study (ETDRS), have been shown to provide accurate and reliable measures of $\mathrm{VA}^{11}$ and have become the gold standard for measuring VA in research. ${ }^{12}$ Furthermore, their design allows us the use of interpolated scoring systems that significantly improve doctors' ability to detect changes in acuity. In such systems equal weighting is given to each letter on the chart, and the score for each letter is incorporated in the overall acuity score.

VA measurement was performed monocularly in each eye. Children normally wearing an optical correction were measured with their correction. The logarithm of the minimum angle of resolution (logMAR) of visual acuity was recorded using an illuminated ETDRS chart at a distance of $4 \mathrm{~m}^{14}$ Note that contrary to Snellen VA the high logMAR figures represent larger letters so lower VA (Snellen VA 1.0 equals 0.0 logMAR). An ETDRS chart has five letters per line, and VA that can be measured ranging from 1.10 to -0.30 logMAR. In any line of the chart, each letter read correctly would reduce the logMAR by 0.02 from the identifying logMAR level of the row above. ${ }^{14}$ Visual acuity measurement was repeated monocularly using two spherical plus-lenses $(S+0.50 D$ and $S+1.00 D)$.

\section{Data analysis}

Statistical analysis was conducted with the Statistical Package for Social Sciences (SPSS for Windows version 10.0). Sensitivity and specificity in detecting RE of VA measurements (without and with the use of plus-lenses) were calculated for both eyes separately. Receiver Operator Characteristic (ROC) curves were plotted and Areas Under the Curves (AUC) including $95 \%$ confidence intervals were calculated. Pearson correlation coefficients $(r)$ were calculated.

\section{RESULTS}

Study population

Nineteen out of the 21 invited primary schools participated. Of the 588 children aged $11-13$ years visiting these schools, $520(88 \%)$ children participated in the present study. Non-participation was due to absence/illness (37 children; $6 \%$ ); no permission of the parents $(29$ children; $5 \%)$, and in $2(<1 \%)$ children autorefractometer 
measurements could not be obtained. Of the 520 school children $52 \%$ was female and $48 \%$ was male. 74 children (15\%) were normally wearing an optical correction (boys $13 \%$ and girls $16 \%$ ).

\section{Refractive errors}

The prevalences of the spherical RE (see figure 1) between right and left eyes showed no apparent difference. In table 1 the prevalences of spherical and astigmatic RE are presented. The results regarding the spherical errors of right eyes of children not normally wearing glasses $(n=446)$ showed $12 \%$ myopia $>-0.50 \mathrm{D}$ and $11 \%$ hyperopia $>+0.50 \mathrm{D}$; for left eyes these figures were $12 \%$ and $9 \%$, respectively. For children normally wearing an optical correction $(n=74)$ the remaining refractive state in right eyes showed $30 \%$ myopia and $16 \%$ hyperopia; for left eyes these figures were $28 \%$ and $11 \%$ respectively.

Figure 1 Histogram showing retrative state (sphere component) of right eyes (mean -0.20. sd=1.34) and let eyes (mean -0.20. sd=1.37) of all children $(N=520)$.

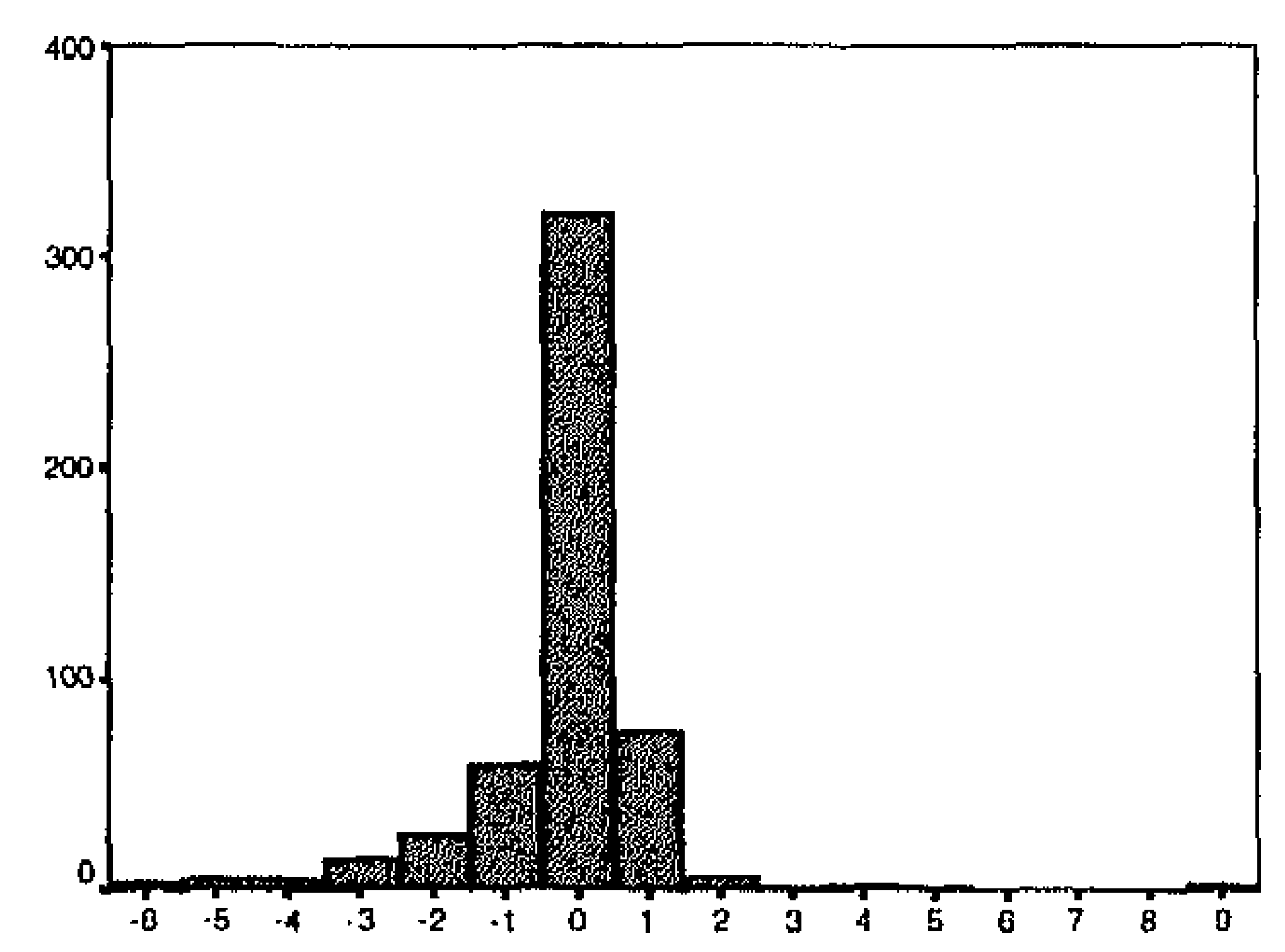

Sohare combonent refractiva slate riaht aves

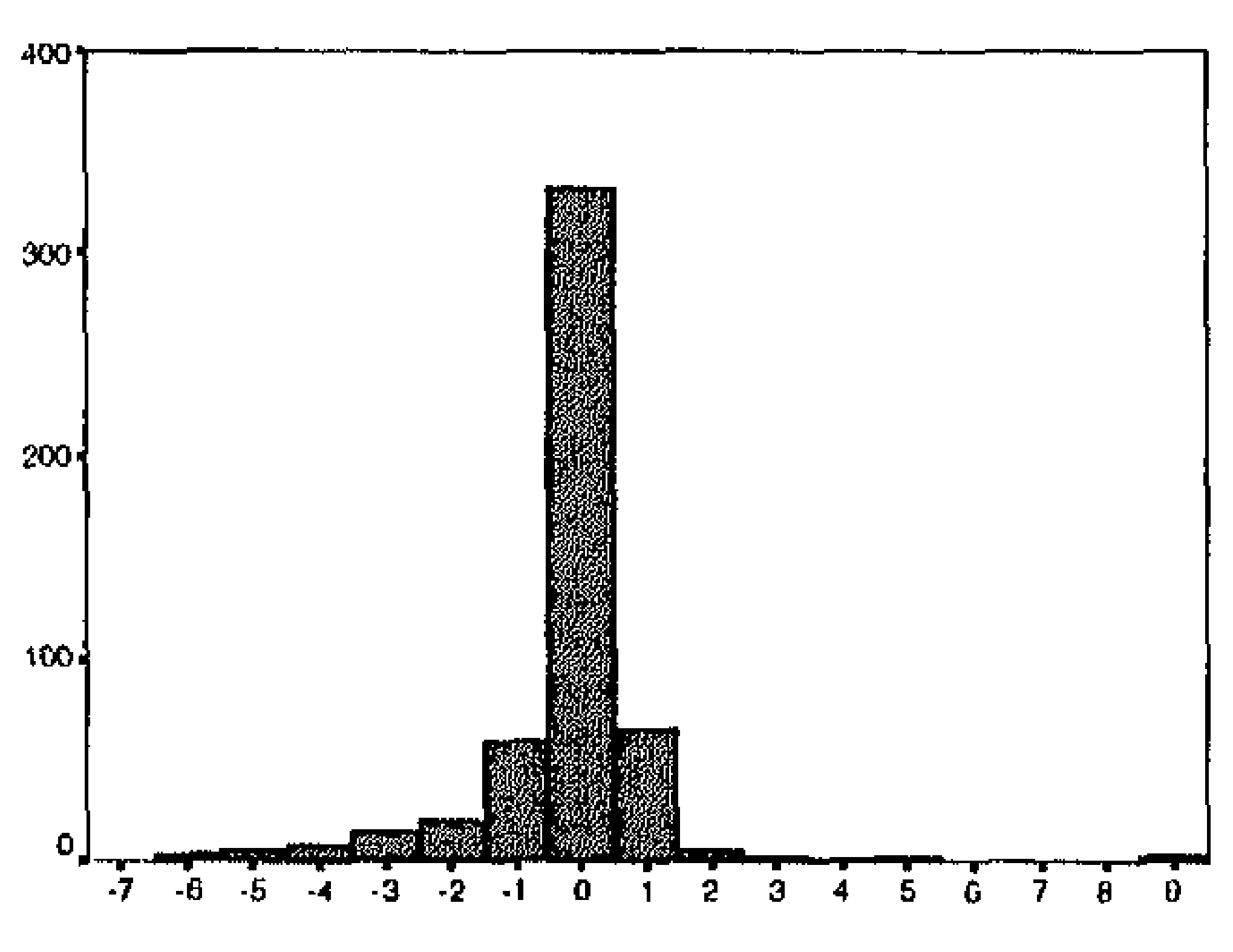

Sohere comonnent of refractive stale left eves

The Pearson correlation coefficient for the spherical part of RE between right and left eyes for all children not normally wearing an optical correction was $0.72(p=<0.01)$. For children normally wearing an optical correction the correlation between right and left eyes was $0.69(\mathrm{p}=<0.01)$.

The distributions of astigmatic RE for right and left eyes showed no statistically significant differences (see table 1). Of the children not normally wearing optical corrections $29 \%$ (right eyes) and $32 \%$ (left eyes) were astigmatic $>0.50 \mathrm{D}$. Of children normally wearing an optical correction $53 \%$ of right and $57 \%$ of left eyes were astigmatic $>0.500$. 
Table 1 Prevalence of RE of right and left eves measured using an autorefractometer. related to optral correction ( $N=520) . M=$ myopia. $E=$ emmetropia. $H=$ hyperopia. $Y=$ astignatism. $N=$ No astigmatism. With(out) glasses=children (not) nomally' wearing glasses. (colum percentages!

\begin{tabular}{|c|c|c|c|c|}
\hline & & \multicolumn{3}{|c|}{ Prevalence of refractive error } \\
\hline & & $\begin{array}{l}\text { Total } \\
\text { group of } \\
\text { children } \\
N=520\end{array}$ & $\begin{array}{l}\text { Children } \\
\text { without } \\
\text { glasses } \\
N=446\end{array}$ & $\begin{array}{l}\text { Children } \\
\text { with } \\
\text { glasses } \\
N=74\end{array}$ \\
\hline $\begin{array}{l}\text { Right eye sphere } \\
\text { component }\end{array}$ & $\begin{array}{l}M \\
E \\
H\end{array}$ & $\begin{array}{l}76(14 \%) \\
383(74 \%) \\
61(12 \%)\end{array}$ & $\begin{array}{l}54(12 \%) \\
343(77 \%) \\
49(11 \%)\end{array}$ & $\begin{array}{l}22(30 \%) \\
40(54 \%) \\
12(16 \%)\end{array}$ \\
\hline $\begin{array}{l}\text { Left eye sphere } \\
\text { component }\end{array}$ & $\begin{array}{l}M \\
E \\
H\end{array}$ & $\begin{array}{l}75(14 \%) \\
399(77 \%) \\
46(9 \%)\end{array}$ & $\begin{array}{l}54(12 \%) \\
354(79 \%) \\
38(9 \%)\end{array}$ & $\begin{array}{l}21(28 \%) \\
45(61 \%) \\
8(11 \%)\end{array}$ \\
\hline $\begin{array}{l}\text { Right eye cylinder } \\
\text { component }\end{array}$ & $\begin{array}{l}\mathbf{Y} \\
\mathbf{N}\end{array}$ & $\begin{array}{l}169(33 \%) \\
351(67 \%)\end{array}$ & $\begin{array}{l}130(29 \%) \\
316(71 \%)\end{array}$ & $\begin{array}{l}39(53 \%) \\
35(47 \%)\end{array}$ \\
\hline $\begin{array}{l}\text { Left eye cylinder } \\
\text { component }\end{array}$ & $\begin{array}{l}Y \\
N\end{array}$ & $\begin{array}{l}184(35 \%) \\
336(65 \%)\end{array}$ & $\begin{array}{l}142(32 \%) \\
304(68 \%)\end{array}$ & $\begin{array}{l}42(57 \%) \\
32(43 \%)\end{array}$ \\
\hline
\end{tabular}

\section{Visual acuity (VA)}

The distribution of the logMAR VA in both eyes of the children (Figure 2) was skewed to the right, with fewer eyes having poorer vision. The median acuity was -0.14 (range, -0.20 to +1.10 ). The correlation between right and left eyes (Pearson $r$ ) for VA was $r=0.65(p=<0.01)$. 
Figure 2 Histograms showing the LogMAR of visual acuity (measured with ETDRS chart) of right and lett eyes of 520 children.

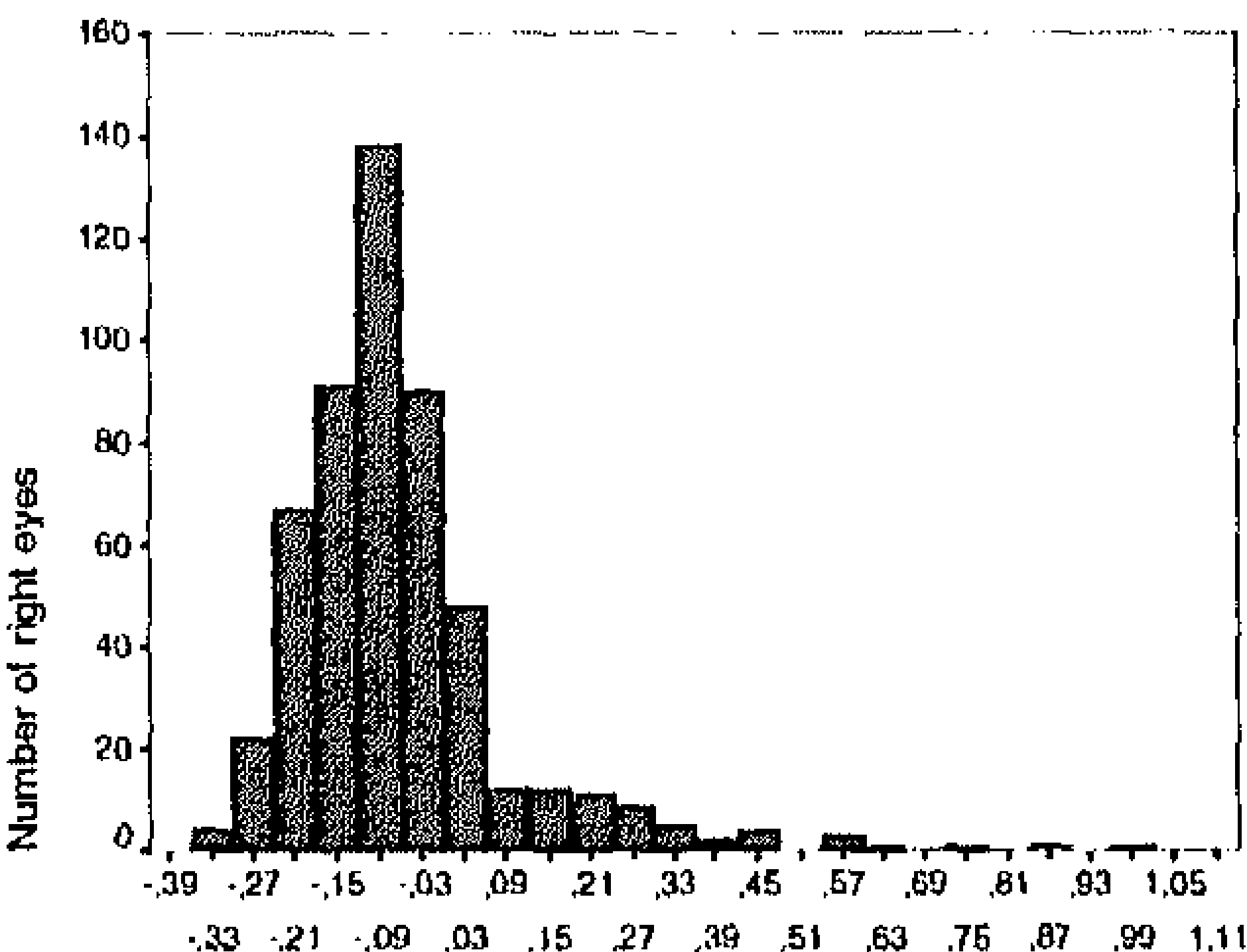

I. OOMAR Visual Acuitu rinht eves

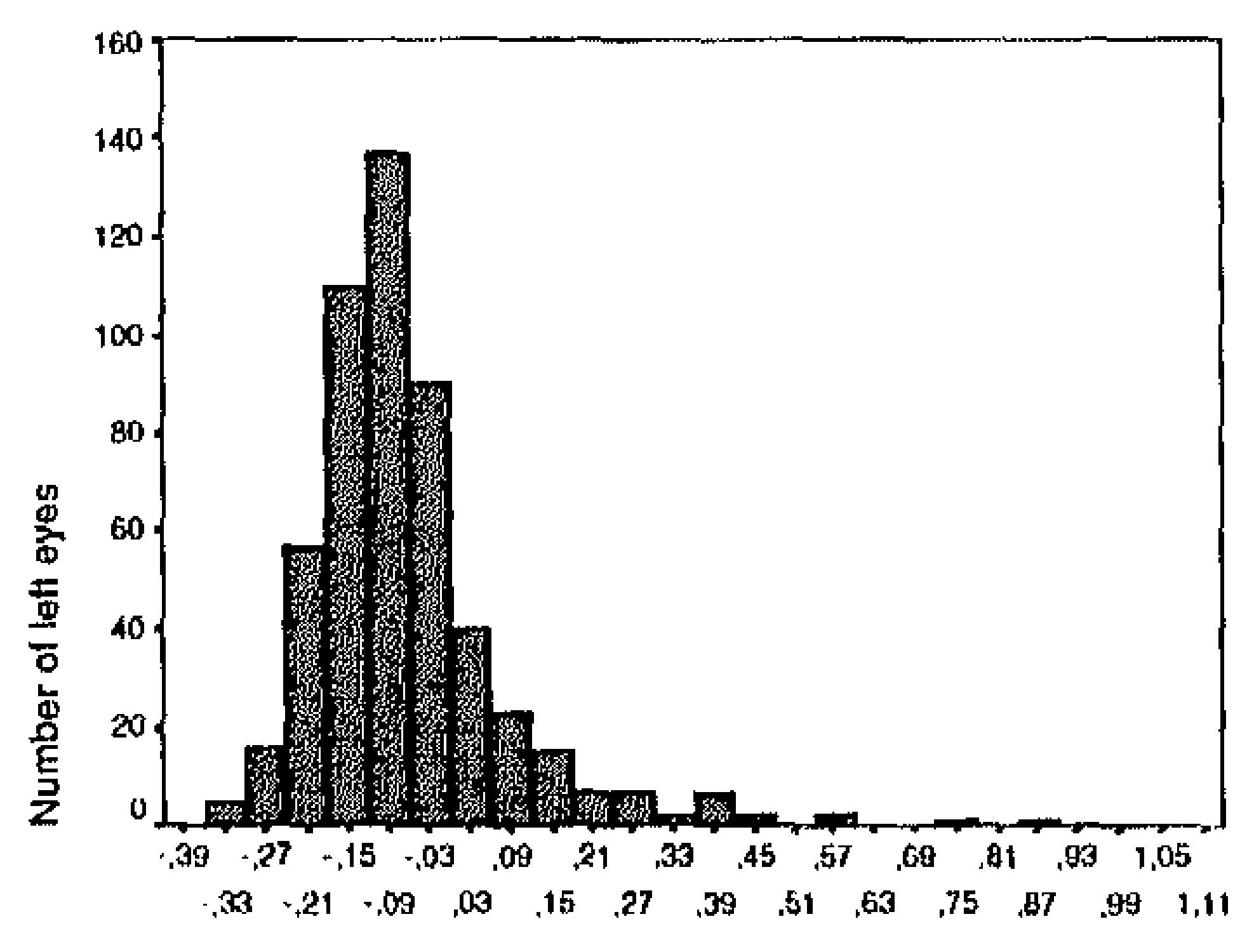

LogMAR Vistual Acuitu lell aves

\section{ROC Curves}

Table 2 shows receiver operating characteristic (ROC) curves of three alternative methods of measurement for myopia, hyperopia and astigmatism. All indices were expressed as percentages with $95 \%$ confidence intervals. Also ROC curves are plotted.

The point of the ROC curve mostly situated near the left upper corner represents a combination of sensitivity and specificity of the used test with optimal discriminatory characteristics. ${ }^{15}$ The profile of the curve showed using VA-measurements only for myopia an optimal sensitivity/specificity profile corresponding to the cut-off of -0.18 in logMAR. For this cut-off point, the sensitivity and specificity of this screening test were $63 \%$ and $78 \%$, respectively (Odds ratio 6.0 ).

In table 2 corresponding ROC-curves are presented for hyperopia and astigmatism, respectively. Based on these curves optimal sensitivity/specificity profiles were for hyperopia using VA-measurements in combination with plus-lenses $(67 \% / 75 \%$; odds ratio 6.1$)$ and for astigmatism using VA-measurements only $(58 \% / 73 \%$; odds ratio 3.0). 
Table 2 ROC curves for three alternative tests for the detection of myopia, hyperopia. and astigmatism in right eyes: 1 . Simple VA measurement ( $=V O D)$. 2. Measurement of VA with $S+0.50 \mathrm{D}$ $(=$ Test 1), and 3. Measurement of VA with $S+1.000(=$ Test 2).

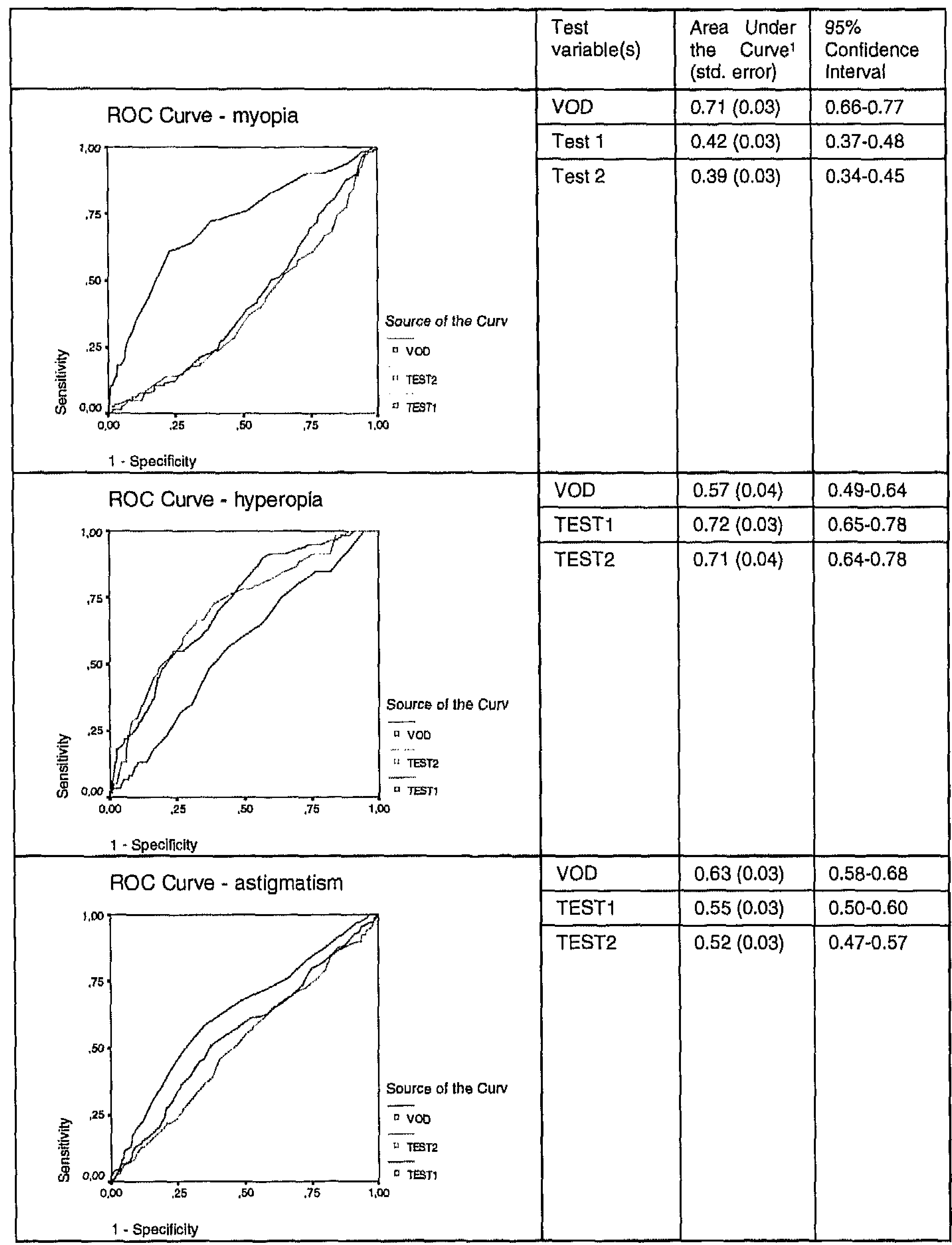

${ }^{1}$ Under the nonparametric assumption

* Point representing optimal combination of sensitivity and specificity 


\section{DISCUSSION}

Measurement of VA proved to be a feasible and reasonably valid measurement method to detect myopia in schoolchildren. VA measurement with plus-lenses showed for myopia diminished sensitivity and specificity, and is therefore not indicated.

In the detection process for hyperopia simple VA measurement (without use of pluslenses) proved to be a poor detection method. However, the use of plus lenses improved both sensitivity and specificity. For hyperopia, measurement of VA with a plus-lens $(0.50 \mathrm{D}$ or $1.00 \mathrm{D})$ showed to be a reasonably valid detection method. No significant differences were found for using $0.50 \mathrm{D}$ or $1.00 \mathrm{D}$ plus-lenses in the detection process of hyperopia. Therefore, in the detection process for hyperopia, adding plus-lenses has additional value for daily practice in primary care.

For the detection of astigmatism, measurement of VA with or without plus lenses proved not to be a valid measurement method.

In our study we defined ametropia as refractive errors $>0.50 \mathrm{D}$. For optical performance small amounts of ametropia are relatively unimportant. For use in general practice we purposely included these smaller amounts of ametropia because they might be important in relation to aspecific health complaints and functional problems. ${ }^{16,17}$ Especially hyperopia or ciliary muscle strain is referred to as the cause of headache, since accommodation might arouse visual stress. ${ }^{18,19}$

Autorefractors give quick and accurate readings of RE, without examiner bias and without the involvement of highly trained clinical personnel. ${ }^{20-22}$ We recognise that noncycloplegic measurements due to accommodation tend to underestimate the hyperopic status. Cycloplegia is a method to detect latent hyperopia or pseudomyopia, but it does not yield adequate information on habitual RE. With this we realize that we measure a different concept than "true" (or absolute) RE.

We were interested in evaluating the children under conditions as close as possible to those under which they usually function in daily life (habitual $R E$ ), were the use of a cycloplegium is not feasible and/or indicated.

Larger standard deviations in RE measurements are everyday facts with which general practitioners have to deal with. If a healthcare worker in an ambulatory setting wants a more thorough investigation of the "real" or "absolute" refractive state he or she normally refers to an ophthalmologist or optometrist for further investigations.

Spherical RE (>0.50D) was present in a quarter of schoolchildren aged between 11 and 13 years ( $14 \%$ myopia and $12 \%$ hyperopia). Astigmatic RE (>0.50D) was present in one third of all schoolchildren. In this study the prevalence of ametropia in children normally wearing an optical correction, was higher than in children not normally wearing an optical correction. Because of the relatively high prevalence of under diagnosed and/or under- or overcorrected RE, more attention should be paid to detecting of RE in children. 


\section{CONCLUSION}

In ambulatory settings simple VA measurement is a useful low-tech method to detect myopia, but not for hyperopia and astigmatism. The use of plus-lenses showed no additional value in detection myopia and astigmatism, but is of significant importance in detecting hyperopia. No difference in additional value where found between the $S+0.50 D$ and $S+1.00 D$ lenses.

Role of the funding source

This study was an academic project involving various disciplines of the Maastricht University; there was no external funding source. The corresponding author had full access to all data in the study and had final responsibility for the decision to submit for publication.

Conflict of interest statement

We declare that we have no conflict of interest.

\section{Acknowledgements}

The authors thank the schoolchildren who participated in this study. Our gratitude also goes to the former Ambiorix Organization (nowadays the Ambiorix Organization is merged into the INNOVO foundation, a group of 61 collaborating primary schools in the southern part of The Netherlands), for their enthusiastic help and logistic support in data collection. We also thank Mark Munnik for assisting in measuring the eyes of the children. 


\section{REFERENCES}

1 World Health Organization. Elimination of avoidable disability due to refractive errors. (WHO/PBL/00.79). Geneva: WHO, 2000.

2 Hendricks TJ, Brabander de J, Horst van der FG, Hendrikse F, Knottnerus JA. Relationship between habitual refractive errors and headache complaints in schoolchildren. Optom Vis Sci. 2007;84(2):137-43.

3 Gil-Gouveia R, Pavo-martins 1. Headache associated with refractive errors- a follow up study. Cephalalgia 1999;19:441-442.

4 Gordon GE, Chronicle EP, Rolan P. Why do we still not know whether refractive error causes headaches? Towards a framework for evidence based practice. Ophthalmic Physiol Opt 2001 Jan;21(1):45-50.

5 Moore BD, Augsburger AR, Ciner EB, Cockrell DA, Fern KD. Optometric clinical practice guideline, care of the patient with hyperopia. American Optometric Association Consensus Panel on Care of the patient with hyperopia. American Optometric Association 1997.

6 Anoh-Tanon MJ, Bremond-Gignac D, Wiener-Vacher SR. Vertigo is an underestimated symptom of ocular disorders: dizzy children do not always need mri. Pediatric Neurology July 2000;23(1):49-53.

7 Tong L, Saw SM, Tan D, Chia KS, Chan WY, Carkeet A, Chua WH, Hong CY. Sensitivity and specificity of visual acuity screening for refractive errors in school children. Optom Vis Sci. 2002;79(10):650-657

8 Lovie-Kitchin JE. Validity and reliability of visual acuity measurements. Ophthal Physiol Opt 1988;8:363-70.

9 Gibson SA, Sanderson HF. Observer variation in ophthalmology. Br J Ophthalmol 1980;64:457-60.

10 Wick B, Schor CMA. Comparison of Snellen chart and S-chart visual acuity assessment in amblyopia. J Am Optom Assoc 1984;55:359-61.

11 Elliot $D B$, Sheridan $M$. The use of accurate visual acuity measurements in clinical anticataract formulation triais. Ophthal Physiol Opt 1988;8:397-401.

12 Sheedy JE. Standards for visual acuity measurement. In: Eye care technology forum proceedings. Bethesda, Maryland: National Institues of Health, 1993.

13 Camparini $M$, Cassinari P, Ferrigno L, Macaluso C. ETDRS-fast: implementing psychophysical adaptive methods to standardized visual acuity measurement with ETDRS charts. invest Ophthalmol Vis Sci 2001;42:1226-31.

14 Young FA, Leary GA, Box RA, Harris E, Baldwin WR, West DC, Johnson C. Comparison of cycloplegic and non-cycloplegic refractions of Eskimos. Am J Optom Arch m Acad Optom 1971;48:814-25.

15 Connell FA, Koepsell TD. Measures of gain in certainty from a diagnostic test. Am J Epidemiol 1985 May;121(5):744-53.

16 Snell S. Eyestrain as a cause of headache and other neuroses. Simpkin, Marshall, Hamilton, Kent and Co. London. 1904:56.

17 Gordon MD. Some headaches in an ophthalmologist's office. Headache 1966 Oct; 6(3): $141-146$.

18 Gil-Gouveia R, Martins IP. Headaches Associated With Refractive Errors: Myth or Reality? Headache 2002 Apr; 42(4): 256-262.

19 Melis $\mathrm{M}$. Headaches associated with refractive errors. Overestimated or overlooked? Headache 2003 Mar; 43(3):297-298.

20 Harvey EM, Miller JM, Dobson V, Tyszko R, Davis AL. Measurement of refractive error in Native American preschoolers: validity and reproducibility of autorefraction. Optom Vis Sci $2000 ; 77: 140-9$.

21 Hiatt RL, Braswell R, Smith L, Patty JW. Refraction using mydriatic, cycloplegic, and manifest techniques. Am J Ophthalmol 1973;76:739-44.

22 Suryakumar $R$, Bobier WR. The manifestation of noncycloplegic refractive state in preschool children is dependent on autorefractor design. Optom Vis Sci 2003;80:578-586. 


\section{Chapter 9}

General discussion \& conclusions

9.1 Most important findings

9.2 Methodological considerations and study implications

9.3 Conclusions and recommendations for practice and research 


\section{INTRODUCTION}

This chapter will summarise the most important results of the study. In addition, attention will be given to some methodological aspects of the study including both its strong points and its limitations. Also the implications of the study will be discussed. Finally, we will make a number of recommendations regarding the practical application of the study results and further research.

\subsection{Most important findings}

In this study we first reviewed the literature on the topic of the relation between RE and aspecific health complaints and functional problems. We then studied the occurrence of $R E$, the relations between RE and aspecific health complaints (headache complaints in schoolchildren, and reported health problems in employees), and the relation between RE and functional problems (school achievement and sickness absence). Moreover, we were looking for a low-tech measurement method to improve the detection of refractive errors in ambulatory settings

In the review of the literature a consistent pattern was reported in which myopes score higher and hyperopes score lower on intelligence testing, compared to emmetropes. Reading ability and school achievement show the same pattern. Reading ability might according to the literature be an intervening factor in the relation between $\mathrm{RE}$ and intelligence.

Consistent trends in the relation between RE and headache complaints or aspecific health complaints were not found. We can conclude from the literature that research until now does not confirm RE as a cause of aspecific health complaints but also does not not exclude $R E$ as a relevant factor in relation with aspecific health complaints and/or functional problems.

If a relation between the occurrence of $R E$ and aspecific health complaints and/or functional problems could be confirmed in future research, for many persons these complaints and/or problems could be avoided or diminished. Therefore further research in this field is indicated (chapter 2).

REs were found to be relatively common in schoolchildren aged $11-13$ years and in hospital employees aged 17-60 years. Distributions of sphere and cylinder deviations are similar for Dutch school children and employees. The prevalence of anisometropia proved to be more prevalent in employees than in schoolchildren. Among older employees anisometropia proved to be more prevalent than in younger employees. Especially in children many eyes are not optimally corrected (chapter 3).

Headache complaints showed a small but statistically significant association with the sphere component of habitual RE in girls and the cylinder component of habitual RE in boys. The associations found between habitual RE and headache complaints, indicates that habitual RE might be a risk factor for headache in children (chapter 4). 
The relatively high prevalence of RE among school children, and its relation with school achievements, indicates that a lot of children are at risk for lower school achievement as a result of (habitual) RE. Spherical ametropic girls without optical corrections showed substantially lower scores on the CITO test than their emmetropic counterparts. In addition, habitual astigmatic children (boys and girls) without optical corrections scored considerably lower (6\% on total score). In these children advice for further secondary education proved in general to be one school type level lower.

In contrast to previous studies ${ }^{1,2}$ we found, especially in girls, not only hyperopia but also habitual myopia to be related to lower school achievement. We have no explanation for the gender differences found in this study.

Although we found a high correlation between right and left eyes for the sphere component of $R E$, mainly right eye RE might be considered to contribute to headaches and lower school achievements (chapter 5 ).

Spherical RE proved to be a risk factor for aspecific health complaints in employees normally not wearing an optical correction. No relation was found between other investigated optometric components of RE (sphere equivalent, cylinder, crosscylinders) and health complaints (chapter 6).

Ametropia was found to be related to aspecific health complaints in hospital employees, and the health complaints involved proved to be related to sickness absence. A direct relation between refractive error and sickness absence could not be confirmed (chapter 7).

In ambulatory settings, simple VA measurement (i.e. without plus-lenses) appeared to be a reasonably valid low-tech method to detect myopia, but not for hyperopia and astigmatism. The use of plus-lenses showed no additional value in detecting myopia and astigmatism, but is of significant importance in detecting hyperopia (chapter 8).

\subsection{Methodological considerations and study implications}

Visual acuity (VA) versus Reiractive error (RE)

Patients with RE, especially in case of higher degrees of RE, often have diminished VA for distance. In ambulatory settings VA is mostly measured using Sneilen charts. If a patient is not able to read small letters, and his or her Snellen VA is for example less than 0.5 , practitioners normally will look for a cause (such as RE) of this diminished VA. If on the other hand a patient is able to read small letters, and the measured Snellen VA is for example 1.0 or more, many practitioners will conclude that the patient is emmetropic and RE can be excluded.

However, despite an emmetropic condition, VA is not necessarily optimal. Various other conditions like neural and retinal disorders, and opacity of cornea, lens and vitreous might influence VA. Moreover in patients small degrees of myopia and/or small to moderate degrees of hyperopia, despite their RE, Snellen VA might be 1.0 or more. VA and RE are different concepts.

In addition to the VA disturbances caused by RE, especially in children, many 
symptoms are suggested to be related to RE. Because this possible relationship is not fully investigated, in our research we studied the relation between $R E$ and aspecific health complaints and functional problems. Since in our study headache complaints and school achievement scores in children and aspecific health complaints in adults proved to be associated with $R E, R E$ seems to be a risk factor (next to VA) which should not be neglected.

Definitions of RE/ cut-off

In our studies we found that spherical RE of $0.50 \mathrm{D}$ or more and astigmatic RE of $0.25 \mathrm{D}$ or more are associated with health complaints and functional problems. Therefore we think that while for optical reasons low degrees of ametropia are relatively unimportant, in relation to aspecific health complaints and functional problems these low degrees might be relevant. In most optometric studies the degree of ametropia is defined at rather higher levels than would be of use in studies concerning health complaints and/or functional problems. Optically unimportant degrees of RE seem to be of clinical importance regarding health complaints. ${ }^{3,4}$

Accommodation. cycloplegia, and measurement

As we have seen in chapter 2 headache, dizziness. and occasionally nausea have been suggested to have their origin in RE. ${ }^{5,6}$ In view of the close topographical and nervous connections between the eye and the brain it is not surprising that headaches have frequently been said to be associated with visual defects. ${ }^{7}$ Traditionally hyperopia or ciliary muscle strain is referred to as the cause of health complaints, since accommodation might arouse visual stress. ${ }^{8,9}$ In our study we indeed found a substantially higher score on headache and aspecific health * complaints in hyperopia. However, also myopia gives a higher score on health complaints compared to emmetropia. From this finding it can be concluded that accommodation alone cannot entirely explain the relation between ametropia and health complaints.

Autorefractors give quick and accurate readings of RE, without examiner bias and without the involvement of highly trained clinical personnel. ${ }^{10,11}$ Accommodation reduces the validity and reliability of the instrument. ${ }^{12-17}$ Although we know that noncycloplegic measurements tend to underestimate the hyperopic status, we chose not to use cycloplegia because we wanted to measure habitual RE. Moreover, in our studies we needed a rapid screening tool to estimate $R E$, because we evaluated the subjects during school time hours (children) and during office hours (hospital employees). Cycloplegic examination would have created a considerable time problem; and therefore if we had used a design with use of cycloplegia, many subjects would not have participated. Due to the side effects of cycloplegia even more subjects would have chosen not to participate.

In view of the absence of cycloplegic measures in the present study, it is likely that the hyperopes will be slightly underestimated. We believe, information gained from cycloplegia (to detect latent hyperopia or pseudo-myopia) would not in itself have lead to different outcomes because we primarily were interested in categorizing the children according to their habitual refractive state rather than in the absolute levels of their refraction deviations. 
A question which can be asked is whether cycloplegic refractive measurement also should be considered as standard of reference outside the optometric environment. In ambulatory settings (for example in general practice, school medicine, or occupational medicine), non-cycloplegic measurement might even better represent the state a person is functioning with (habitual refractive state). Until now this question is not addressed in literature.

Right and left eyes

A human being normally functions with two eyes. The refractive state of the pair of eyes is not biologically independent and therefore from a statistical point of view we were not allowed to use both eyes information at the same time in our models. The question then arises how RE of a subject should be defined. In literature most studies use right eye measurements only, mainly because of high correlations of optometric measurements between both eyes. What the arguments are to choose for right eyes (and not for left eyes) is not clear.

An average value of right and left eye measures does not solve the problem because totally different RE-states might result in the same (and therefore meaningless) average value. For example if a persons refractive error in his right eye is $S-4.00 D$ and in his left eye is $S+4.00 \mathrm{D}$, the average value would be S0.00D. This person is than considered to be emmetropic which is not the case at all.

Another possible idea is to use from each subject the eye with the lowest degree of $\mathrm{RE}$ (as the best eye), or with the highest degree of RE (as the worst eye), in studies relating $R E$ and outcome measures other than VA.

We chose to evaluate the influence of both eyes separately in our studies.

Although we found a high correlation between right and left eyes for the sphere component of $\mathrm{RE}$, mainly right eye refractive error proved to contribute to headaches and lower school achievements in children. We have no clear explanation for this finding. Visual information acquired using both eyes alternating may be different from information acquired using one eye only. Also information acquired through right and left cerebral hemispheres may be different. Another reason not to use one eye only might be dominance of one of the eyes. ${ }^{18}$ We did not check for eye dominance in our studies. Although some hypotheses are given above, we are not able to give detailed explanations for these differences. For scientific reasons it is at least clear that in this type of investigation one should analyse the data for both eyes separately.

\section{Gender differences}

In our study the differences found between boys and girls are also remarkable. We have no explanation for the gender differences found in this study. Until now these differences have not been reported in the literature.

\section{Sample}

Our study was carried out on a large, non-clinical study population and the response was high. A question that can be asked is whether selection bias could have been introduced. We consider this unlikely. For the schoolchildren the response rate was very high and the reasons for not participating were not related to RE. Part of the 
group of employees were on sickness leave or were working on night shift and many others had practical or logistic reasons not to participate; however, we have no reason to assume that non-participation (due to other work shifts and/or being occupied by their work) was related with refractive state.

Cross-sectional design

Generally, with a cross-sectional study, it is not easy to determine the direction of an association. However, with our subject of investigation it is unlikely that lower school achievement, sickness absence, headache or aspecific health complaints cause ametropia or astigmatism. It is therefore reasonable to assume that in the association between ametropia and/or astigmatism on the one hand and aspecific health complaints and functional problems on the other, the former will precede the latter. When considering an etiological interpretation, an unknown causal factor might be responsible for both refractive error and lower school achievement. In principle mental retardation could be such a factor, but in our study population mentally retarded children were not included. Other (hypothetical) common etiological factors related to both refractive error and the outcome measures used were not found in literature. Therefore, in our opinion, it is plausible that the relations we found have causal significance.

\section{Screening}

Screening is a public health service in which members of a defined population, who do not necessarily perceive they are at risk of, or are already affected by a disease or its complications, are asked a question or offered a test, to identify those individuals who are more likely to be helped than harmed by further tests or treatment to reduce the risk of a disease or its complications. ${ }^{19}$ Criteria for appraising the viability, effectiveness and appropriateness of a screening programme for habitual RE as developed by us are based on the criteria developed by Wilson and Jungner ${ }^{20}$ (See Table 1) in 1968 and address the condition, the test, the treatment and the screening programme.

Since these original criteria were developed, the breadth of screening has extended to include risk factors (e.g. blood pressure or cholesterol) or susceptibility (e.g. genetic markers for cancer or HIV status) for disease. The criteria were extended with ethical, legal, and socio-behavioural issues considered across all domains, and within a framework that recognises fundamental human rights. The screening test should be simple, safe, precise and validated. The distribution of test values in the target population should be known and a suitable cut-off level defined and agreed. There should be evidence of early treatment leading to better outcomes than late treatment. The opportunity cost of the screening programme (including testing, diagnosis and treatment, administration, training and quality assurance) should be economically balanced in relation to expenditure on medical care as a whole (i.e. value for money).

In our study we found high prevalences of RE in school children and employees. RE was associated with health complaints and important socio-economic functional outcome measures (school achievement and sickness absence). RE can be 
measured and corrected relatively simple at low costs. Although still a number of questions are unanswered, screening for RE seems to be potentially worth while.

Table 1 Wilson and Lungner critena for screening applied at soreening ton habitual RE

\begin{tabular}{|c|c|c|}
\hline \multicolumn{2}{|c|}{$\begin{array}{l}\text { Wilson and Jungner criteria for } \\
\text { screening }\end{array}$} & \multirow{2}{*}{$\begin{array}{l}\text { RE } \\
\text { RE is a common cause of visual impairment. RE } \\
\text { (especially high myopia) is also associated with ocular } \\
\text { diseases such as glaucoma and retinal detachment. } \\
\text { Habitual RE proved to be associated with headache } \\
\text { complaints and lower school achievements in children } \\
\text { aged 10-12 years of age. Habitual RE also proved to } \\
\text { be associated with aspecific health complaints in } \\
\text { employees normally not wearing an optical correction. } \\
\text { RE seems to be an important health problem. }\end{array}$} \\
\hline $\begin{array}{l}\text { Knowledge of } \\
\text { disease }\end{array}$ & $\begin{array}{l}\text { The condition should be } \\
\text { important }\end{array}$ & \\
\hline & $\begin{array}{l}\text { There must be a recognisable } \\
\text { latent or early symptomatic } \\
\text { stage }\end{array}$ & $\begin{array}{l}\text { RE can be measured in almost all persons with or } \\
\text { without symptoms. }\end{array}$ \\
\hline & $\begin{array}{l}\text { Natural course of condition, } \\
\text { including development from } \\
\text { latent to declared disease, } \\
\text { should be adequately } \\
\text { understood }\end{array}$ & $\begin{array}{l}\text { The etiological mechanism how RE might cause non- } \\
\text { visual complaints and/or functional problems is } \\
\text { unclear. Ciliary muscle fatigue (in case of hyperopia), } \\
\text { brow furrowing, and contraction of the pericranial and } \\
\text { neck muscles in an attempt to maintain a clear image } \\
\text { have been suggested as etiological mechanisms. An } \\
\text { interesting thought mentioned by Gordon }{ }^{\prime} \text { is that a } \\
\text { minor RE might more often cause headache } \\
\text { complaints than a major RE. }\end{array}$ \\
\hline \multirow[t]{3}{*}{ Knowledge of test } & Suitable test or examination & $\begin{array}{l}\text { AE can be measured during full refractioning, } \\
\text { automatic refractioning, Standard VA screening and } \\
\text { VA screening with use of plus lenses. Measurements } \\
\text { can be done with or without use of a cycloplegium. }\end{array}$ \\
\hline & Test acceptable to population & $\begin{array}{l}\text { Measurement of RE using a cycloplegium might not } \\
\text { be accepted to the population due to its side effects. } \\
\text { RE measurement using VA screening with and without } \\
\text { Use of plus lenses seems to be a efficient and } \\
\text { acceptable alternative. }\end{array}$ \\
\hline & $\begin{array}{l}\text { Case finding should be } \\
\text { continuous (not just a "once } \\
\text { and for all" project) }\end{array}$ & $\begin{array}{l}\text { RE screening can easily be introduced in conventional } \\
\text { continuous visual screening programmes. }\end{array}$ \\
\hline \multirow[t]{3}{*}{$\begin{array}{l}\text { Treatment for } \\
\text { disease }\end{array}$} & $\begin{array}{l}\text { Accepted treatment for patients } \\
\text { with recognised disease. }\end{array}$ & $\begin{array}{l}\text { The majority of refractive errors can be corrected } \\
\text { successfully using spectacles, contact lenses or } \\
\text { refractive surgery. }\end{array}$ \\
\hline & $\begin{array}{l}\text { Facilities for diagnosis and } \\
\text { treatment available }\end{array}$ & $\begin{array}{l}\text { In developed countries facilities for diagnosis and } \\
\text { treatment are sufficiently available. }\end{array}$ \\
\hline & $\begin{array}{l}\text { Agreed policy concerning whom } \\
\text { to treat as patients }\end{array}$ & $\begin{array}{l}\text { Optically unimportant degrees of RE seem to be of } \\
\text { clinical importance regarding health complaints. } \\
\text { Further research is necessary to define degree of RE } \\
\text { which should be treated. }\end{array}$ \\
\hline $\begin{array}{l}\text { Cost } \\
\text { considerations }\end{array}$ & $\begin{array}{l}\text { Costs of case finding (including } \\
\text { diagnosis and treatment of } \\
\text { patients diagnosed) } \\
\text { economically balanced in } \\
\text { relation to possible } \\
\text { expenditures on medical care } \\
\text { as whole }\end{array}$ & $\begin{array}{l}\text { RE can be measured and corrected at relatively low } \\
\text { costs. Costs of not correcting (lower school } \\
\text { achievements, more sickness absence, aspecific } \\
\text { health complaints) seem to be higher than costs of } \\
\text { correcting. }\end{array}$ \\
\hline
\end{tabular}


Opportunities for early detection

In our cross sectional studies we found associations between habitual RE and aspecific health complaints and functional problems. These associations seem, as discussed earlier, to point at habitual RE as cause of these complaints and problems. If our findings could be generalised, and if future research has investigated the use of the correction of habitual RE in respect to aspecific health complaints, screening for habitual RE might be of importance.

Under these assumptions it would be strongly advisable to detect and correct refractive errors at an earlier stage. This would give ametropic and astigmatic school children the possibility to diminish their risk for lower school achievement.

A problem here is to define the ideal age for screening on refractive error due to the fact that young children are hyperopic and grow towards emmetropia with age.

Screening at too young an age would logically lead to many false positive findings. Refraction screening at the age of roughly 6 years might be feasible.

Both the relationship between RE and health complaints as well as the usefulness of correcting for RE regarding relief from non-visual complaints are not yet fully known. RE can be measured and often corrected easily, at relatively low costs. If the relation between RE and the occurrence of aspecific health complaints and/or functional problems could be confirmed in prospective research, for many persons these complaints and/or problems could be avoided or diminished.

In ambulatory settings simple VA measurement is a useful low-tech method to detect myopia, but not for hyperopia and astigmatism. The use of plus-lenses showed no additional value in detection myopia and astigmatism, but is of significant importance in detecting hyperopia.

In order to detect REs in ambulatory settings we advise to use simple VA measurement first. If VA is not adequate RE should be excluded. In cases in which $V A$ is considered to be adequate, to repeat VA measurement with the use of a pluslens is of use to detect cases of hyperopia that would be missed when plus-lenses are not used.

\subsection{Conclusions and recommendations for practice and research}

The main aim of this thesis was to gain insight in the relation between $R E$, aspecific health complaints and functional problems. We also studied the additional value of the introduction of the use of plus-lenses in standard VA-measurement in an ambulatory setting in order tot detect REs.

\section{Practice}

RE are relatively common in schoolchildren aged $11-13$ years and in hospital employees aged 17-60 years. RE seems to be related to aspecific health complaints and functional problems. Since RE can be corrected relatively easily, more attention for these errors is advisable. We advise incorporating the measurement of RE in the diagnostic process in children with headache complaints. Also in people with 
aspecific health complaints not normally wearing an optical correction, measurement of spherical RE should be considered more often.

In children, as a consequence of habitual ametropia (habitual spherical deviations of $0.50 \mathrm{D}$ or more, and habitual cylindrical deviations of $0.25 \mathrm{D}$ or more), advice for further secondary education proved in general to be one level of school type lower. Integration of early refraction screening in vision screening programmes is worth considering.

In ambulatory settings simple VA measurement is a useful low-tech method to detect myopia, but not for hyperopia and astigmatism. The use of plus-lenses showed no additional value in detection myopia and astigmatism, but is of significant importance in detecting hyperopia.

Research

We realise that the prevalence of REs varies enormously in different geographic areas and in ethnic populations. ${ }^{21-24}$ An extended application of this study is desirable, especially to find out whether our findings can be generalised to other groups. When prevalences are high, and if our findings could be generalised, also detecting and correcting of relatively small amounts of RE would become even more worth considering. This would give ametropic people the possibility to diminish their risk for aspecific health complaints.

Future research in this field might be designed to further clarify the role of right and left eyes, and the additional value of using cycloplegia. Future research also might be directed at understanding the natural course of RE in relation to aspecific health complaints and functional problems.

Now we have found that habitual RE is associated with health complaints and functional problems, the question arises whether correction of these RE with glasses will diminish these complaints and problems. Future prospective research, preferably a randomized screenings-study with correction of habitual RE as intervention, to answer this question is worthwhile to be performed. 


\section{REFERENCES}

1 Grosvenor T. Refractive state, intelligence test scores, and academic ability. Am J Optom \& Arch Am Acad Optom 1970;47:355-361.

2 Teasdale TW, Fuchs J, Goldschmidt E. Degree of myopia in relation to intelligence and educational level. Lancet 1988; 10:1351-54.

3 Snell S. Eyestrain as a cause of headache and other neuroses. Simpkin, Marshall, Hamilton, Kent and Co. London. 1904:56.

4 Baker AR. A statistical inquiry as to the relief and cure of migraine by the correction of errors of refraction. Opthal. Record. 1904;16:1-6.

5 Waters WE. Headache and the eye. The Lancet 1970 Aug; 2(7670):467-468.

6 Gordon DM. Some headaches in an ophthalmologist's office. Headache 1966 Oct (6): $140-145$.

7 Eckhardt LB, McLean JM, Goodell H. Experimental studies on headache: the genesis of pain from the eye. Proc Assoc Res Nerv Ment Dis 1943;209-227.

8 Vaughan D., Asbury T. (Textbook) General Ophthalmology $8^{\text {th }}$ edition, 1977 Lange Medical Publication:288-290.

9 Moore BD, Augsburger AR, Ciner EB, Cockrell DA, Fern KD. Optometric clinical practice guideline, care of the patient with hyperopia. American Optometric Association Consensus Panel on Care of the patient with hyperopia. American Optometric Association 1997.

10 El-Defrawy S, Clarke WN, Belec F, Pham B. Evaluation of a handheld autorefractor in children younger than 6. J Pediatr Ophthalmol Strabismus. 1998;35(2):107-9.

11 Harvey, E. M., Miller, J.M., Dobson, V., Tyszko, K., \& Davis, A.L. Measurement of refractive error in Native American preschoolers: validity and reproducibility of autorefraction. Optom Vis Science. 2000 Mar;77(3):140-149.

12 Wesemann W, Dick B. Accuracy and accommodation capability of a handheld autorefractor. $J$ Cataract Refract Surg 2000 Jan; 26(1):62-70.

13 Harvey EM, Miller JM, Dobson V, Tyszko R, Davis AL. Measurement of refractive error in Native American preschoolers: validity and reproducibility of autorefraction. Optom Vis Sci 2000 Mar; $77(3): 140-9$.

14 Young FA, Leary GA, Box RA, Harris E, Baldwin WR, West DC, Johnson C. Comparison of cycloplegic and non-cycloplegic refractions of Eskimos. Am J Optom Arch $m$ Acad Optom 1971 Oct; 48(10):814-25.

15 Hiatt RL, Braswell R, Smith L, Patty JW. Refraction using mydriatic, cycloplegic, and manifest techniques. Am J Ophthalmol 1973 Nov; 76(5):739-44. Suryakumar R, Bobier WR. The manifestation of noncycloplegic refractive state in preschool children is dependent on autorefractor design. Optom Vis Sci 2003 Aug; 80(8):578-586.

17 Pesudovs K, Weisinger HS. A comparison of autorefractor performance. Optom Vis Sci 2004 Jul; 81(7):554-8.

18 Pointer JS. Patterns of hand-eye dominance. Br. J. Optom. \& Disp. 1999; 7(3): 88-90.

19 UK National Screening Committee; Definition of screening.

20 JMG Wilson and $G$ Jungner in Principles and Practice of Screening for Disease, WHO 1968.

21 Lin LL, Shih YF, Hsiao CK, Chen CJ, Lee LA, Hung PT. Epidemiologic study of the prevalence and severity of myopia among schoolchildren in Taiwan in 2000. J Formos Med Assoc 2001 Oct; 100(10): 684-91.

22 Villareal MG, Ohlsson J, Abrahamsson M, Sjöström A, Sjöstrand J. Myopisation: The refractive tendency in teenagers. Prevalence of myopia among young teenagers in Sweden. Acta Ophthalmol Scand 2000 Apr; 78(2):177-81.

23 Kuo A, Sinatra RB, Donahue SP. Distribution of refractive error in healthy infants. $J$ AAPOS 2003 Jun; 7(3): 174-77.

24 Junghans BM, Crewther SG. Prevalence of myopia among primary school children in eastern Sydney. Clin Exp Optom 2003 Sept; 86(5):339-45. 


\section{Summary}

Refractive error (RE), especially myopia, is related to visual acuity (VA) and ocular diseases. In addition to diminished VA and ocular diseases, the literature suggests that RE (especially hyperopia) also might cause non-visual complaints and functional problems. Although RE is suggested to cause aspecific health problems and functional problems, research on this relationship seems to be a neglected domain.

The aim of our research was to gain more insight in the relation between $R E$, aspecific health complaints and functional problems.

A literature search (chapter 2) was performed on the possible influence of RE on the occurrence of non-visual complaints and functional problems. The literature search included Medline searches (1966-2005) in which used keywords were: refractive error, hyperopia, myopia, complaints, symptoms, headache, fatigue, intelligence, reading, and dizziness. Moreover we searched in reference lists for other relevant articles. Articles published in English language (or with abstract in English) were included if the abstracts reported on possible relations between RE and medical complaints and/or functional problems.

Studies discussing the relation between RE and health complaints do not show consistent relations between RE and headache complaints or aspecific health complaints. Little if any robust evidence supporting the theory that RE causes headache complaints was found.

On the relation between RE and functional problems, a consistent pattern was found in which myopes score higher and hyperopes score lower on intelligence and reading tests, compared to emmetropes. Reading ability and school achievement show the same pattern. Reading ability might according to the literature be an intervening factor in the relation between refractive error and intelligence.

Research until now does not confirm RE as a cause of aspecific health complaints, but also does not exclude $R E$ as a relevant factor in relation with aspecific health complaints and/or functional problems. If a relation between the occurrence of RE and aspecific health complaints and/or functional problems could be confirmed in future research, for many persons these complaints and/or problems could be avoided or diminished at relatively low costs.

During the last few decades the prevalence of myopia has increased worldwide, especially in Asia. We investigated the prevalence of habitual REs (i.e. without the use of a cycloplegium) and anisometropia in a Dutch population of children and employees (chapter 3 ). In a cross-sectional study REs of both eyes of 520 children (aged 11-13 years) and 444 hospital employees (aged 17-60 years) were measured using an autorefractometer (Topcon, RM-8000B). The measurements were performed without the use of a cycloplegium in order to best fit the refractive state in daily life. The Pearson correlation coefficient ( $r$ ) was used to analyse correlations between right and left eyes. For testing differences between gender and age subgroups chi-square tests were used. 
Among school children $28 \%$ of right eyes were myopic $>0.50 \mathrm{D}$ and $8 \%$ hyperopic $>0.50 \mathrm{D}$. For sphere equivalent power (SEP) Pearson's $r$ between right and left eyes was 0.93 . Mean cylinder component in right eyes was $0.26 \mathrm{D}$ [0.00D to $4.50 \mathrm{D}]$. Anisometropia $>1.00 \mathrm{D}$ was present in $4.6 \%$ of children; $22 \%$ of children were not optimally (>0.50D) corrected.

Among hospital employees $30 \%$ of right eyes were myopic $>0.50 \mathrm{D}$ and $10 \%$ hyperopic $>0.50 \mathrm{D}$. For sphere equivalent Pearson's $r$ between right and left eyes was 0.53. Mean cylinder component in right eyes was $0.35 \mathrm{D}$ [0.00D to 5.75D].

Anisometropia $>1.00 \mathrm{D}$ was present in $25 \%$ of employees. In employees aged $40-60$ years anisometropia was more frequently present than in employees aged 17-39 years $(30 \%$ versus $18 \%, p=0.02$, Cramer's $V=0.15)$.

REs are common in schoolchildren aged 11.13 years and in hospital employees aged 17-60 years. Distributions of sphere and cylinder deviations are similar for Dutch school children and employees. Surprisingly, anisometropia proved to be more prevalent with age. In children many eyes $(22 \%)$ are not optimally corrected.

In chapter 4 we aimed to gain insight into the relation between habitual RE (sphere and

astigmatism) and headache complaints in children. In a cross-sectional study the habitual refractive state of 487 children, aged between 11 and 13 years, was measured using an autorefractometer (Topcon, RM-8000B). Headache complaints were measured using a questionnaire. Data were analysed using Pearson correlation coefficients, bivariate analysis, and multiple logistic regression analysis.

For right eyes we found $15 \%$ habitual myopia $<-0.50 \mathrm{D}$ and $12 \%$ habitual hyperopia $>+0.50 \mathrm{D}$; habitual astigmatism $>0.25 \mathrm{D}$ was found in $33 \%$ of children. Pearson $R$ between right and left eyes was 0.76 for the spherical component and 0.42 for the cylindrical.

In the total group of children $70 \%$ reported the occurrence of headache in the last year. These headaches were reported as "often or frequent" by $37 \%$ of children, "severe" by $15 \%$, "with long duration" by $45 \%$, and "with severe burden" by $27 \%$. In the total sample we found various associations between gender, sphere/cylinder components of habitual RE, and headache complaints. Headache was reported more in girls than in boys. Of the total variance of headache complaints in girls, the sphere component of habitual RE explained $4 \%$ of frequency, $6 \%$ of intensity, $2 \%$ of duration, and $2 \%$ of amount of burden. Of the total variance of headache complaints in boys the cylinder component of habitual RE explained $3 \%$ of frequency, and $4 \%$ in amount of burden.

Habitual RE and headache complaints are relatively common conditions in schoolchildren aged between 11 and 13 years. Headache complaints showed a small but statistically significant association with the sphere component of habitual RE in girls and the cylinder component of habitual RE in boys. The associations found between habitual RE and headache complaints, indicates that habitual RE might be a risk factor for headache in children. 
Because uncorrected REs might induce lower school achievement, we investigated in chapter 5 the relation between habitual REs and school achievement. In a crosssectional study the habitual refractive state of 464 children, aged 11-13 years, was measured using an autorefractometer (Topcon, RM-8000B). School achievement on areas 'language', 'mathematics', 'study skills', and 'world orientation' was measured using the Dutch CITO test. Analysis of variance (ANOVA) was used to investigate the relation between habitual RE and the CITO test scores.

High correlations between right and left eyes were found for all optometric measurements. Spherical component of habitual RE revealed prevalences of $13 \%$ for myopia $<-0.50 \mathrm{D}$ and $11 \%$ for hyperopia $>+0.50 \mathrm{D}$. Astigmatism $>0.25 \mathrm{D}$ was found in $59 \%$ of children; of these $58 \%$ showed horizontal/vertical orientation and $42 \%$ oblique orientation.

For the total sample no relation was found between spherical and astigmatic components of habitual RE and school achievement scores. However, spherical ametropic girls not normally wearing an optical correction scored substantially lower than their emmetropic counterparts (10\% on the total score and $9 \%$ on language). Also, astigmatic boys not normally wearing an optical correction scored lower $6 \%$ on total score, $8 \%$ on study skills and $7 \%$ on world orientation) than non-astigmatic boys. No relation was found between the orientation of astigmatism and school achievement scores.

Girls with spherical ametropia not normally wearing an optical correction and astigmatic children not normally wearing an optical correction performed substantially lower on their school achievement scores. In these children advice for further secondary education proved in general to be one school type level lower. As lower school achievement may be a consequence of small habitual RE, integration of early refraction screening in vision screening programmes is worthwhile to consider.

In chapter 6 we investigated the role of various habitual RE components in relation to aspecific health complaints. Habitual RE of 444 hospital employees were measured (with optical correction if applicable) using an autorefractometer (Topcon, RM$8000 \mathrm{~B}$ ). Health complaints were assessed in a questionnaire (Dutch Questionnaire of Work and Health, VAG). The relation between various habitual RE components and health complaints was analysed by analysis of variance (ANOVA), for both eyes separately.

Habitual spherical RE of all employees revealed prevalences of $7 \%$ for myopia $>0.50 \mathrm{D}$ and $19 \%$ for hyperopia $>0.50 \mathrm{D}$. Astigmatism $>0.50 \mathrm{D}$ was found in $65 \%$; of these cases, $57 \%$ showed horizontal/vertical orientation and $43 \%$ oblique orientation. Between right and left eyes, and between employees with and without optical correction, no differences were found in the prevalence of the various habitual RE components. In employees normally wearing an optical correction (58\% of all employees), no differences in health complaints were found for the various refractive components. However, in employees normally not wearing an optical correction, higher health complaints scores were found in those with spherical hyperopia and myopia. On a health-scale ranging from 0.00 to 1.00 , emmetropes scored 0.18 whereas myopes and hyperopes scored 0.24 and 0.29 respectively $(p=0.03)$. In relation to health complaints, other $R E$ components investigated did not play a role. Spherical hyperopia and spherical myopia proved to be a risk factor for aspecific 
health complaints in employees normally not wearing an optical correction. No relation was found between all other investigated optometric components of habitual $R E$ and aspecific health complaints. Since spherical RE can be corrected relatively easy, attention for these errors is advisable.

In chapter 7 we investigated the relation between habitual $R E$, aspecific health complaints and sickness absence. Habitual RE of 423 hospital employees was measured using an autorefractometer (Topcon, RM-8000B) and related to aspecific health complaints and sickness absence. Health complaints were measured using a questionnaire. Sickness absence was assessed on the basis of organizational absence records. Analysis of variance (ANOVA) and multiple logistic regression analysis were used.

A direct relation between habitual RE and sickness absence was not found. On a scale ranging from 0.00 to 1.00 , hyperopes (19\% of all employees) reported more aspecific health complaints than emmetropes $(0.23$ versus $0.16 ; p=.01)$. Hyperopic men $(0.19$ versus $0.12 ; p=.05)$ and hyperopic employees aged 40 years or older ( 0.25 versus $0.15 ; p=.01)$ reported more aspecific health complaints, than their emmetropic counterparts.

Compared to employees with low health complaint scores, employees with high health complaint scores were absent one episode more per two years $(p=.01)$; also their average sickness episode lasted 14 to 23 days longer $(p=.02)$. In total this group showed a higher total sickness absence of 16 to 26 days per year $(p<.01)$.

We did not find a direct association between refractive error and sickness absence. The prevalence of habitual RE in employees is relatively high. Spherical component of habitual RE is associated with health complaints. Accordingly, besides measuring visual acuity in screening programs, the measurement of habitual RE is worthwhile considering.

Now RE in the previous chapters has been indicated one of the possible risk factors for aspecific health complaints and functional problems, for health care workers in ambulatory settings a reliable and feasible method to detect $R E$ is necessary. We investigated in chapter 8 the additional diagnostic value of using plus-lenses next to visual acuity (VA) measurement in order to detect $R E$ in ambulatory settings In a cross-sectional study REs of 520 children, aged 11-13 years, were measured using an autorefractometer (Topcon, RM-8000B). Autorefractive measurements were used to categorize ametropia. Using an ETDRS chart, VA was measured without and with spherical plus-lenses (S+0.50D and $S+1.00 \mathrm{D}$ ). Sensitivity and specificity for detecting RE by VA-measurements without and with use of the plus-lenses were used to plot ROC curves, using autorefractor measurements as the reference standard.

No differences were found in the prevalence of the various components of RE between right and left eyes. RE measurements revealed $74 \%$ emmetropia [+0.50D, $-0.50 \mathrm{D}], 14 \%$ myopia $<-0.50 \mathrm{D}$, and $12 \%$ hyperopia $>+0.50 \mathrm{D}$. Astigmatism $>0.50 \mathrm{D}$ was present in $33 \%$ of the children.

ROC curves for VA-measurements alone showed an Area Under the Curve (AUC) for myopia of 0.71 (Confidence Interval 0.66-0.77); for hyperopia $0.57(0.49-0.64$ ), and for astigmatism 0.63 (0.58-0.68) 
VA-measurement with use of plus-lenses (0.50D) showed for myopia an AUC of 0.42 (0.37-0.48), for hyperopia $0.72(0.65-0.78)$, and for astigmatism $0.55(0.50-0.60)$. Both used plus-lenses showed equal results in this respect.

Based on ROC curves optimal sensitivity/specificity profiles were reached for myopia using VA-measurements only ( $63 \% / 78 \%$; odds ratio 6.0 ), for hyperopia using VAmeasurements in combination with plus-lenses $(67 \% / 75 \%$; odds ratio 6.1$)$ and for astigmatism using VA-measurements only (58\%/73\%; odds ratio 3.0$)$.

In ambulatory settings, simple VA-measurement (i.e. without plus-lenses) is a reasonably valid low-tech method to detect myopia, but not for hyperopia and astigmatism. The use of plus-lenses next to VA-measurement is of significant importance in detecting hyperopia.

The general conclusions of our study on the relation between REs, aspecific health complaints and functional problems reveal that small habitual REs are associated with aspecific health complaints and functional problems (chapter 9 ).

The question arises whether correction of these RE with glasses will diminish these complaints and problems. If further prospective research confirms our findings, and if correction of habitual RE will lead to diminished aspecific health complaints and/or functional problems, a screening-study for habitual RE is worthwhile 


\section{Dankwoord}

Als een onbezonnen avontuur is dit project van start gegaan. Nu de eerste stap gezet is (het proefschrift is zo goed als af), is het tijd om iedereen te bedanken die op welke wijze dan ook een bijdrage heeft geleverd aan de totstandkoming ervan. Dit project getuigt dat men met enthousiasme ook zonder budget iets kan bereiken.

Allereerst natuurlijk dank aan mijn promotor André Knottnerus. Tijdens mijn studie geneeskunde in Maastricht, was jij al in het eerste studiejaar een van mijn begeleidiers van SPO-onderwijs. Je stimulerende scherpzinnige analyse van het procesgebeuren; je erudiete persoonlijkheid hebben ertoe geleid dat ik mijn studie geneeskunde ook bij/met jou wilde afronden middels dit onderzoek. Je hebt me veel ruimte gegeven in de aanpak van het project en me alle kansen geboden om te groeien in de wetenschap. Dat waardeer ik zeer. Ik heb met name tijdens de laatste fase genoten van de verpakking die steeds mooier de inhoud mede vorm gaf.

Fred Hendrikse, tweede promotor, niet minder erudiet. Bedankt dat je een vreemde huisartsgeneeskundige eend in je oogheelkundige bijt toeliet. Je open houding naar de maatschappelijke relevantie van je vakgebied bewijzen dat je niet alleen kijk hebt op een goede visus, maar ook een goede visie hebt.

John de Brabander, je enthousiaste manier waarop we samen als een optometrisch circus de 19 scholen zijn langsgegaan, je aberrometrische toevoegingen en overige inhoudelijke en procesmatige begeleiding tijdens dit project hebben me het gevoel gegeven dat er anno 2007 nog wezenlijke ontdekkingsreizen gemaakt worden.

Frans van der Horst, je ad hoc opmerkingen, vrijwel altijd op het laatste moment, waren vaak van dien aard dat het denkproces weer eens een heel andere wending aan moest nemen dan voorzien. Je frisse gedachtes hebben er voor gezorgd dat ik nu zelf ook begrijp wat ik heb geschreven.

Dank ook aan alle andere mensen die direct of indirect geholpen hebben bij het uitvoeren van het onderzoek. Marlou Vankan, Eefje van Oosterhout, Marc Munnik, Marijke van den Berg, Nicola Chateau, Karel van Wanrooij, Christel van der Loo, en vele anderen welke eigenlijk alle ook niet ongenoemd mogen blijven. Dank aan de industrie voor het ter beschikking stellen van de meetapparatuur.

Natuurlijk wil ik ook de deelnemers aan het onderzoek niet vergeten:

De medewerkers van het stafbureau (Hay Freriks) van de stichting Ambiorix voor de logistieke advisering en ondersteuning van het project binnen hun organisatie. De scholen van de stichting Ambiorix die zo gastviij waren om ons te ontvangen. De kinderen die de vragenlijst in de klas hebben ingevuld en zich lieten onderzoeken. De medewerkers van (Jan van Wersch, Imelda Essers) het Atrium Medisch Centrum, locatie Heerlen die vragenlijsten hebben ingevuld en zich lieten onderzoeken.

Zonder een idee geen onderzoek, eerlijk is eerlijk: Jo Baggen heeft het hem weer gelapt: iemand te enthousiasmeren om een deel van de meerdelijns-oogheelkunde te bestuderen.

Vader en moeder, dank voor jullie voorbeeldfunctie waarbij het voor jullie zo vanzelfsprekendheid is om af te maken waar je aan begonnen bent. Het is niet altijd makkelijk....

Bedankt allemaal! 


\section{About the author}

\section{CURRICULUM VITAE}

Theo Johan Wilhelm Hendricks was born on the tenth of February 1969 in Amstenrade, the Netherlands. In 1987 he finished his secondary education at the Rombouts' College in Brunssum. He studied economics for one year at the University of Tilburg, followed by medicine at the University of Maastricht, where he graduated in 1994.

After a residentship in general medicine in England, he worked during two years as senior house officer (cardiology, psychiatry and occupational medicine, respectively). He participated in a vocational training programme at the department of General Practice at the Maastricht University; which he finished in 1999.

Subsequently, he worked as a general practitioner in a health centre in Rheindahlen (Germany) for the Dutch Army.

In 2005 he completed a master degree in epidemiology at the Free University in Amsterdam. In 2007 he completed a master degree in laws, labour and health at the Maastricht University.

From 2003 to 2007 he has been attached to the University of Maastricht, faculty of general practice where he was involved in undergraduate and postgraduate medical education. Since January 2008 he is working as General Practitioner in Nederweert.

\section{CURRICULUM VITAE}

Theo Hendricks werd geboren in Amstenrade op 10 februari 1969, In 1987 behaalde hij zijn WWO-diploma aan het Romboutscollege in Brunssum, en begon hij de studie economie in Tilburg. Na het behalen van zijn propedeuse economie begon hij de studie geneeskunde in Maastricht. In 1994 behaalde hij zijn artsexamen. $\mathrm{Na}$ enkele maanden in Engeland te hebben gewerkt als arts-assistent inwendige geneeskunde, werkte hij van 1994 tot 1997 als arts-assistent cardiologie en psychiatrie in het Atrium Medisch Centrum op de locaties Heerlen (voorheen De Wever ziekenhuis) en Brunssum (voorheen St. Gregrius ziekenhuis).

In 1997 startte hij de huisartsopleiding aan de Universiteit Maastricht. Van 1999 tot 2004 heeft hij als huisarts gewerkt in een gezondheidscentrum in Rheindahlen (Duitsland) voor het Nederlandse Ministerie van Defensie. Van 2003 tot 2007 was hij verbonden aan de vakgroep huisartsgeneeskunde in Maastricht voor het verzorgen van onderwijs in het basiscurriculum. Sinds januari 2008 is hij werkzaam als huisarts in Nederweert. 


\section{Glossary of used terms and abbreviations}

Absolute hyperopia

Accommodation

Amblyopia

Anisometropia

Astigmatism

Autorefractor

CITO

Cycloplegia

Diagnostic refractioning

D

VAG

Emmetropization

Habitual RE
Hyperopia that cannot be overcome by accommodation.

The ability of the eyes to focus clearly at various distances.

A unilateral or bilateral reduction in corrected visual acuity in the absence of any obvious structural anomalies or ocular disease.

Differences between right and left eye ametropia.

Refractive anomaly due to different refraction of light in perpendicular meridians of the eye. This in most cases is caused by different curvatures of the outer surface of the cornea. Regular astigmatism can be corrected using cylindrical lenses.

The orientation of astigmatism (axis $\theta$ ) is referred to as with-the-rule (WTR) when the most positive power of the correcting lens is close to horizontal (negative cylinder axes between $0^{\circ}$ and $15^{\circ}$, and between $180^{\circ}$ and $165^{\circ}$ ), against-the-rule (ATR) when the most positive power of the correcting lens is close to the vertical meridian (negative cylinder axes $90^{\circ}$ plus and/or minus $15^{\circ}$ ), with other orientations being considered as oblique.

Devise to objectively determine the optical state of the eye.

Dutch Institute developing assessment tests. (Centraal Instituut voor Toets Ontwikkeling)

Pharmaceutical agent used to block accommodation.

Method to diagnose RE.

Diopter

Dutch Questionnaire of Work and Health (Vragenlijst Arbeid en Gezondheid)

The process by which significant neonatal refractive errors are reduced in the direction of emmetropia.

State of RE with which a person normally functions. 


\section{HARE}

Hyperopia

= hypermetropia

$=$ farsightedness

IHS

Jackson crossed cylinder

Latent hyperopia

Manifest hyperopia

Myopia

=nearsightedness

Odds ratio

PPAT

Pathologic hyperopia

Presbyopia

Pseudo-myopia

RE

SE

VAS
Headache associated with refractive error

Refractive condition in which the light entering the non-accommodated eye is focused behind the retina.

International Headache Society

Cross cylinders are combinations of two cylinders whose powers are numerically equal and of opposite sign and whose axes are perpendicular to each other. The Jackson cross cylinder is usually mounted in a ring with a handle at 45 degrees from the axis so that a twirl of the handle changes the cross cylinder to a second position.

Hyperopia that is habitually overcome by accommodation, determined by cycloplegic refraction.

Hyperopia (either facultative or absolute) that is determined by non-cycloplegic refraction.

Refractive condition in which the light entering the non-accommodative eye is focused in front of the retina.

The odds ratio is a measure of effect size. It is defined as the ratio of odds of an event occurring in one group to the odds of it occurring in another group, or to a samplebased estimate of that ratio.

Paediatric Pain Assessment Tool

Hyperopia due to abnormal anatomy, maldevelopment, ocular disease, or trauma, not to normal biological variation.

A reduction in accommodative ability that occurs normally with age and necessitates a plus lens addition for satisfactory seeing at near.

Presentation of higher degree of myopia than the natural state, due to accommodation.

Refractive error

Sphere equivalent Power

Visual Analogue Scale 
Visual acuity (VA)

WHO

WHQ
The clearness of vision that depends upon the sharpness of focus of the retinal image and the integrity of the retina and visual pathway.

World Health Organization

Waters' Headache Questionnaire 